\title{
Type B Investigation of the Iridium Contamination Event at the High Flux Isotope Reactor on September 7, 1993
}

\author{
Investigation Board
}

H. B. Piper, MMES, Chairman

R. D. Cheverton, ORNL, Engineering

Technology Division

S. A. Hamley, ORNL, Office of Radiation

Protection

J. P. Hill, ORNL, Atomic Trades and

Labor Council

T. B. Lee, United Energy Services

Corporation

J. A. West, Y-12 Plant, Assessments

Manager

Date Published: March 1994

Prepared by

MARTIN MARIETTA ENERGY SYSTEMS, INC.

Oak Ridge, Tennessee 37831

for the

U.S. DEPARTMENT OF ENERGY

under contract DE-AC05-84OR21400 


\section{CONTENTS}

Page

LIST OF FIGURES $\ldots \ldots \ldots \ldots \ldots \ldots \ldots \ldots \ldots$ iii ACKNOWLEDGEMENTS $\ldots \ldots \ldots \ldots \ldots \ldots \ldots \ldots \ldots \ldots \ldots \ldots$

ACRONYMS $\ldots \ldots \ldots \ldots \ldots \ldots \ldots \ldots \ldots \ldots \ldots \ldots \ldots \ldots \ldots$ vi

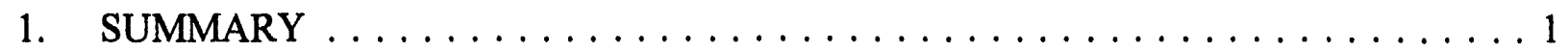

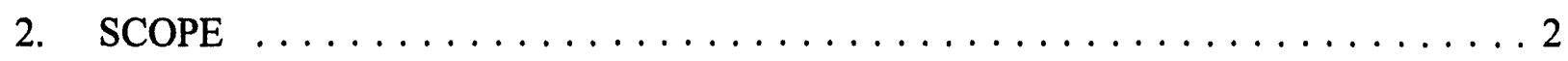

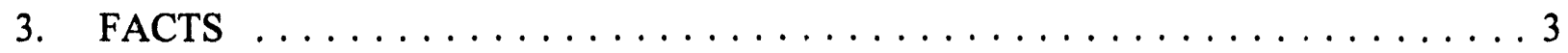

3.1 BACKGROUND INFORMATION $\ldots \ldots \ldots \ldots \ldots \ldots \ldots \ldots \ldots \ldots$

3.2 SEQUENCE OF EVENTS $\ldots \ldots \ldots \ldots \ldots \ldots \ldots \ldots \ldots \ldots \ldots \ldots$

3.3 RECEIPT, HANDLING, AND IRRADIATION $\ldots \ldots \ldots \ldots \ldots \ldots \ldots$

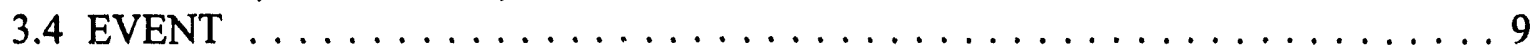

3.5 PLANNING, CLEANUP, AND CASK KEMOVAL

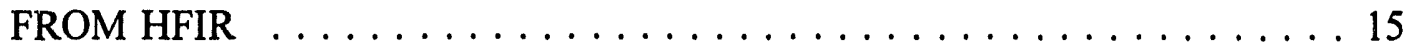

3.6 TARGET ROD RETRIEVAL AND ANALYSIS AND CASK RECOVERY $\ldots \ldots \ldots \ldots \ldots \ldots \ldots \ldots \ldots \ldots \ldots \ldots \ldots \ldots \ldots$

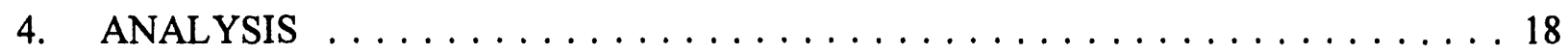

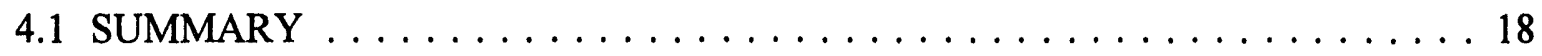

4.2 RECEIPT, HANDLING, AND IRRADIATION $\ldots \ldots \ldots \ldots \ldots \ldots \ldots \ldots 18$

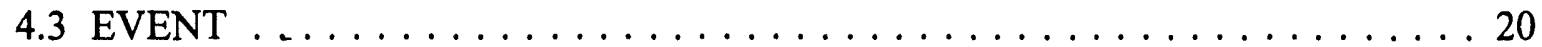

4.4 TECHNICAL EVALUATION $\ldots \ldots \ldots \ldots \ldots \ldots \ldots \ldots \ldots \ldots \ldots \ldots$

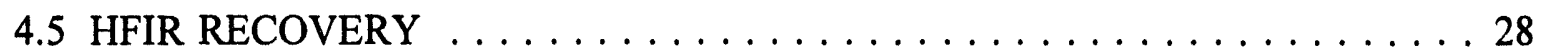

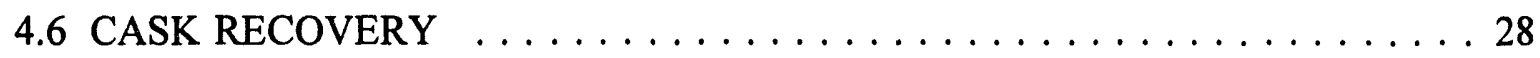

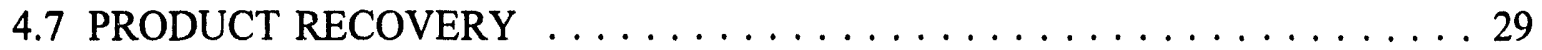

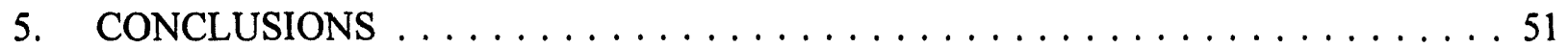

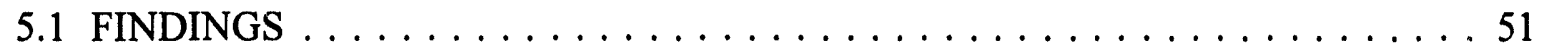

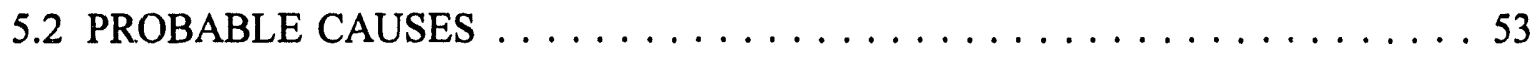

5.3 JUDGEMENT OF NEEDS $\ldots \ldots \ldots \ldots \ldots \ldots \ldots \ldots \ldots \ldots \ldots \ldots$

6. SIGNATURES OF BOARD MEMBERS $\ldots \ldots \ldots \ldots \ldots \ldots \ldots \ldots \ldots \ldots \ldots \ldots$

7. APPENDICES

APPENDIX A. MEMORANDA OF APPOINTMENT $\ldots \ldots \ldots \ldots \ldots \ldots \ldots$

APPENDIX B. EVENTS AND CAUSAL FACTORS $\ldots \ldots \ldots \ldots \ldots \ldots \ldots$ 


\section{CONTENTS (CONT.)}

Page

APPENDIX C. ORNL ORGANIZATION CHART $\ldots \ldots \ldots \ldots \ldots \ldots$

APPENDIX D. CALCULATION OF CRITICAL TEMPERATURE OF IRIDIUM TARGET ROD CORRESPONDING TO

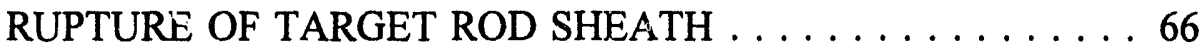

APPENDIX E. CALCULATION OF TEMPERATURE ALONG LENGTH OF IRIDIUM TARGET ROD WHILE END WELD IS BEING MADE $\ldots \ldots \ldots \ldots \ldots \ldots \ldots 71$

APPENDIX F. CALCULATION OF LONGITUDINAL EXTENT OF END CONSTRAINT PERTAINING TO SHEATH PORTION OF IRIDIUM TARGET ROD

8. EXHIBITS

EXHIBIT A. OCCURRENCE REPORT ORO-MMES-X10HFIR-1993-0030 $\ldots 74$

EXHIBIT B. MAY 25, 1993, MEMO M. J. SHERICK TO CHUCK OTTINGER . . . . . . . . . . . . . . 83

EXHIBIT C. EXPERIMENTAL SAFETY ASSESSMENT, ESA-HFIR-92-1 $\ldots 85$

EXHIBIT D. JUNE 10, 1993, MEMO R. W. HOBBS

TO CRONE/FARRAR/WHALEY . . . . . . . . . . . . . 105

EXHIBIT E. AUGUST 24, 1993, MEMO C. L. OTTINGER

TO K. E. McCORMACK . . . . . . . . . . . . . . . . . . . . . 109

EXHIBIT F. NOTES ON CRITIQUE OF HIGH RADIATION

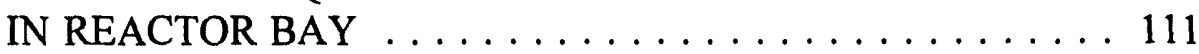

EXHIBIT G. ALARA PLAN FOR CASK TRANSPORT $\ldots \ldots \ldots \ldots \ldots 114$

EXHIBIT H. PRESENTATION ON CASK TRANSPORT $\ldots \ldots \ldots \ldots \ldots 123$ 


\section{LIST OF FIGURES}

FIGURE

Page

3.1 Map of Oak Ridge Area and the HFIR Site $\ldots \ldots \ldots \ldots \ldots \ldots \ldots$

4.1 Rupture in Upper End of Iridium Target Rod IR-75 $\ldots \ldots \ldots \ldots \ldots \ldots \ldots$

4.2 Iridium Target Design Details $\ldots \ldots \ldots \ldots \ldots \ldots \ldots \ldots \ldots \ldots \ldots \ldots \ldots$

4.3 Iridium Target-Rod Shipping Cask (HRLEL Carrier) $\ldots \ldots \ldots \ldots \ldots \ldots \ldots$

4.4 Vertical Cross Section of Iridium Target-Rod Shipping Cask

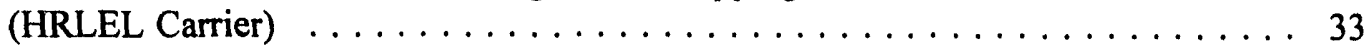

4.5 Transfer Can for Iridium Target Rods $\ldots \ldots \ldots \ldots \ldots \ldots \ldots \ldots \ldots \ldots$

4.6 Record of Locations of Iridium Target Rods in Transfer Can . . . . . . . . 35

4.7 Photo of Top of Iridium Target Rod Transfer Can Showing Several Iridium Pellets and a Dark Fluify Material . . . . . . . . . . . 36

4.8 Close-up View of Rupture in Iridium Target Rod IR-75, Showing Vacant Iridium-Pellet Recesses and Discoloration of Interior Surfaces . . . . . . . 37

4.9 Schematic of Assembly for Pressurizing Void Space in Ruptured

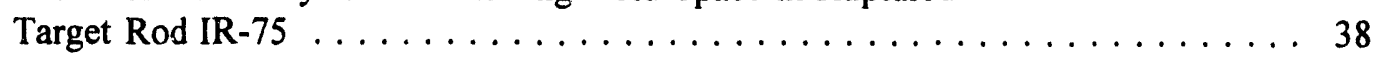

4.10 Evidence and Location of Leak in Upper End of

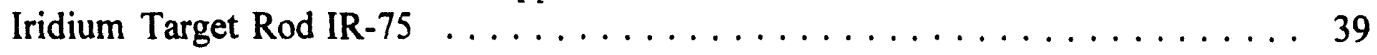

4.11 Photo of Upper End of Iridium Target Rod IR-75, Showing Whisker, Unusual Looking Portion of Weld, and Approximate Site of Leak . . . . . . . 40

4.12 Close-up View of Iridium Target Rod IR-75, Showing Lack of Swelling of the Sheath Opposite the Location of the Rupture . . . . . . . . . . . . . . 41

4.13 Cutting Sequence and Polishing Directions for Upper End

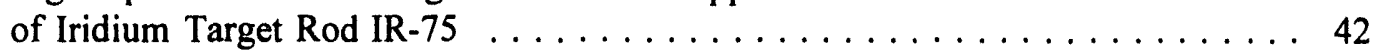

4.14 Close-up of Cut End of Cutoff Upper End of Iridium Target Rod IR-75 . . . . . 43

4.15 Polished Outer Surface of Upper End of Iridium Target Rod IR-75, Showing Cross Section of Leakage Path Close to Outer Surface (Polishing Depth $\sim 0.014$ in.) . . . . . . . . . . . . 44 
4.16 Second Step in Polishing of Outer Surface of Upper End of Iridium Target Rod IR-75, Showing Changing Pattern of Voids (holes)

Compared to that Revealed by First Step in Polishing (Fig. 4.15)

4.17 Final Step in Polishing of Outer Surface of Upper End of Iridium

Target Rod IR-75, Showing Triangular-Shaped Opening to Annulus

Between Sheath and Core (Polishing Depth $\sim 0.023$ in.)

4.18 Enlarged View Through Triangular Opening in Upper End of Iridium

Target Rod IR-75, Showing Fiberlike Foreign Material

4.19 Longitudinal Cross Section of Cutoff Upper End of Iridium Target Rod IR-75 ( $90^{\circ}$ from Leak Site), Showing Difference in Location of End of Clearance (Annulus) Between Sheath and Core in this Particular Plane

4.20 Enlarged View of Weld Area at End of Narrower Clearance Between Target Rod Sheath and Core (Mirror Image Enlargement of Fig. 4.19), Showing Porosity and Unfused Interface

4.21 Radiograph of Six Unirradiated Iridium Target Rods, Showing Nonbonds (Unfused Areas) at the Ends of Two Sheaths

D.1 Tensile Properties for 6061 Aluminum in the T0, T4, and T6

Conditions

D.2 Calculated Critical Temperatures Corresponding to Rupture of a HFIR Iridium Target Rod Containing Water

D.3 Saturation Pressure vs Temperature for Steam 70 
Members of the Investigation Board want to thank those in the Research Reactors, Chemical Technology, Metals and Ceramics, and Plant and Equipment Divisions for their cooperation and input to the Koard's investigation. The Board also wishes to acknowledge the contributions of Les Smith (United Energy Services Corporation), Dennis Heatherly (ORNL/ETD), Al Longest (ORNL/ETD), Ken Thoms (ORNL/ETD), who worked directly with the Board, and of Darlene Stratman (ORNL/ETD) and Lois Szluha (MMES/CEP) for their efforts in preparation of the manuscript. 


\section{ACRONYMS}

$\begin{array}{ll}\text { ALARA } & \text { As Low As Reasonably Achievable } \\ \text { CTD } & \text { Chemical Technology Division } \\ \text { DOE-ORO } & \text { Department of Energy, Oak Ridge Operations } \\ \text { DRD } & \text { Direct-reading Dosimeter } \\ \text { HFIR } & \text { High Flux Isotope Reactor } \\ \text { HP } & \text { Health Physics } \\ \text { I\&C } & \text { Instrumentation and Controls } \\ \text { INEL } & \text { Idaho National Engineering Laboratory } \\ \text { IPDP } & \text { Isotope Production and Distribution Program } \\ \text { M\&C } & \text { Metals and Ceramics Division } \\ \text { MORT } & \text { Management Oversight and Risk Tree } \\ \text { ORFS } & \text { Office of Operational Readiness and Facility Safety } \\ \text { ORNL } & \text { Oak Ridge National Laboratory } \\ \text { P\&E } & \text { Plant and Equipment Division } \\ \text { RRD } & \text { Research Reactors Division } \\ \text { RSS } & \text { Reactor Shift Supervisor } \\ \text { RWP } & \text { Radiation Work Permit } \\ \text { TLD } & \text { Thermoluminescent Dosimeter }\end{array}$




\section{SUMMARY}

On Tuesday, September 7, 1993, at the Oak Ridge National Laboratory (ORNL), area radiation alarms sounded during a routine transfer of a shielding cask from the High Flux Isotope Reactor (HFIR) pool side to a transport truck. The cask contained approximately 60,000 Curies of iridium-192, which was produced at HFIR for use as commercial and medical radiography sources.

The event resulted in small amounts of iridium being released from the cask onto the reactor-bay floor. The floor was cleaned, and the cask containing the iridium was shipped to a hot cell at Building 3047 on October 3, 1993.

The event was caused by rupture of one of the iridium target rods after it was loaded into the cask for normal transport operations. The rupture was the result of steam generation in the target rod soon after the target rod was placed in the cask. Water had entered the target rod through a tiny defect in a weld while the target rod was in the reactor under pressure $(\sim 500 \mathrm{psi})$.

While the target rods were in the reactor and reactor pool, there was sufficient cooling to remove the heat generated by radioactive decay of the iridium, and this prevented steam generation inside the target rod. When the target rod was loaded into the dry transport cask, the temperature increased sufficiently to result in boiling of the trapped water and produced high enough pressure to result in rupture. The escaping steam ejected some of the iridium pellets, making it possible for some of them to escape the shielding cask.

This event was reported as Occurrence Report Number ORO--MMES-X10HFIR-1993-0030, dated September 8, 1993 (Exhibit A).

Analysis of the circumstances related to the event indicates that the following conditions were probable causes:

1. Less than adequate welding procedures, practices, or techniques, material controls, or inspection methods, or some combination of these, could have led to weld defects such as those that adversely affected the integrity of target rod IR-75.

2. Less than adequate secondary containment in the cask allowed iridium "pellets" to escape. 
A Type B Investigation Board (Board) was appointed by the Manager of the Department of Energy, Oak Ridge Operations (DOE-ORO), to investigate the September 7, 1993, iridium contamination event at the HFIR site at ORNL. The Board was charged with three tasks: (1) determine the causes of the event; (2) prepare a report on the event (this document, DOE/OR-2004) in accordance with DOE Order 5484.1, Environmental Protection, Safety, and Health Protection Information Reporting Requirements; and (3) provide recommendations to prevent similar events. Formal memoranda of appointment are included in Appendix A.

The Board reviewed and analyzed physical evidence from the event, interviewed witnesses and involved personnel, and reviewed and evaluated documentation. The Board used methods prescribed in DOE accident-investigation protocols, including the Events and Causal Factors Chart (Appendix B), Barrier Analysis, Change Analysis, and Management Oversight and Risk Tree (MORT) techniques to ensure evaluation completeness.

The Board focused its review on management systems; procedures and practices; design, manufacture, and handling of the iridium target rods; the event; and the recovery of the cask and iridium product. Special emphasis was placed on the process for acceptance, control, and handling of target rods (from initial receipt through shipping); as-low-as-reasonably-achievable (ALARA) preplanning; and mockup training for recovery operations. 


\section{FACTS}

\subsection{BACKGROUND INFORMATION}

\subsubsection{General Description of the ORNL Site}

ORNL is one of the three major facilities in Oak Ridge, Tennessee, operated for DOE by Martin Marietta Energy Systems, Inc. (Energy Systems). Founded during World War II under the code name X-10, ORNL supported the mission of the Manhattan Project to produce materials for the world's first nuclear weapons. ORNL is now one of the nation's largest multidisciplinary national laboratories. A map of the Oak Ridge area and the HFIR site appears in Fig. 3.1. An organization chart for ORNL is presented in Appendix C.

\subsubsection{Activities at the ORNL Site}

Activities at ORNL are focused on basic research, technology development, and other technological challenges that are important to DOE and to the nation. ORNL also performs research and development for non-DOE sponsors when such activities complement DOE missions and address important national or international issues.

The mission of ORNL is to support DOE in six broad areas: energy production and conservation technologies, physical and life sciences, scientific and technological user facilities, environmental protection and waste management, science and technology transfer, and education.

Since its origin in 1942, ORNL has remained a major center for research, development, and production missions that involve the use of a wide variety of radioactive and hazardous materials. In support of these missions, special facilities and equipment were designed to manage these materials. Since startup in 1965, HFIR has been used to produce intense neutron beams for neutron diffraction experiments, materials irradiation studies, and radioisotope production.

\subsubsection{Iridium-192 Production}

Idaho National Engineering Laboratory (INEL) has primary responsibility for producing iridium-192. Iridium-192 is used as radiation sources for medical applications and industrial radiography and is produced by irradiating iridium with neutrons from a reactor core. The iridium is in the form of small discs, often called wafers or pellets, and herein referred to as pellets. Where it is not known if whole pellets or only portions of pellets existed, these are referred to as "particles."

The pellets are normally about $0.125 \mathrm{in}$. in diameter and $0.010 \mathrm{in}$. thick, but other shapes are also used. The pellets are loaded into machined recesses in the outer surface of a 
cylindrical core that is placed in a sheath and the ends welded, making a target rod that is then irradiated in a reactor. The irradiated target rods are loaded into a transfer can (hereafter referred to as the can) that is then loaded into a cask and transported to a hot cell, where the iridium is processed into a form suitable for use by the commercial customer.

The very high neutron fluxes in the Advanced Test Reactor at INEL and HFIR produce iridium-192 that has more radioactivity per unit mass than can be achieved in lower-flux reactors, and this makes a superior radiography source that is preferred by the commercial customer. Currently, all iridium-192 produced for the United States radiography industry is produced in these two reactors.

When the Advanced Test Reactor cannot irradiate enough iridium to meet the commercial demand or when INEL hot-cell process facilities cannot meet the commercial demand, INEL requests ORNL to make up the difference. The request from INEL normally comes to the ORNL Chemical Technology Division (CTD) Isotope Production and Distribution Program (IPDP) manager.

When the IPDP manager receives the request, it is passed to the Iridium Program manager who contacts the Research Reactors Division (RRD) experiment coordinator to determine the availability of HFIR to irradiate the iridium. Further, the Iridium Program manager contacts the Irradiated Fuels Examination Laboratory (Building 3525) staff, to determine if the iridium can be processed after it is irradiated in HFIR.

Once it is determined that ORNL can produce the iridium, the IPDP manager contacts INEL and requests that the target rods be delivered to ORNL in time for the necessary testing to be done before they go into HFIR. In addition to the target rods, INEL is to provide ORNL (1) a sample of each batch of aluminum material used to fabricate each target rod; (2) a letter certifying conformance to all requirements; and (3) the fabrication package for each target rod shipped.

\subsubsection{Organizational Relationships}

The iridium target rods that are irradiated in HFIR are designed, fabricated, welded, and inspected by INEL. CTD is responsible for the scheduling and planning of iridium production activities at ORNL. The target rods are inspected at ORNL by the Health and Safety Research Division Nuclear Medicine Group prior to irradiation, and RRD is responsible for irradiating the target rods and loading the irradiated target rods into the cask. Plant and Equipment Division (P\&E) rigging crews and personnel deliver the loaded cask to the Metals and Ceramics Division (M\&C) Irradiated Fuels Examination Laboratory for processing. The packaged product is certified for shipping by the Radioactive Material Shipping and Packing organization of CTD and is transported to the shipping and receiving facility for pickup by the customers. 
DOE has a site office at the HFIR site. This office is responsible for oversight of the reactors and the isotope program. The Office of Nuclear Energy (DOE Headquarters) has programmatic responsibilities for the facility. DOE site personnel were involved in all aspects of the recovery.

\subsection{SEQUENCE OF EVENTS}

To clearly present the large number of facts identified during the course of the investigation and to enable the reader to more easily understand this event, the facts are presented in four groups. The first group of facts, "RECEIPT, HANDLING, AND IRRADIATION," relates to the handling of the target rods at ORNL in preparing them to be irradiated, including testing of the target rods and the samples, placing them in the reactor, and removing them from the reactor after irradiation. The second group of facts, "EVENT," relates to the event and amelioration of the event. The third group of facts, "PLANNING, CLEANUP, AND CASK REMOVAL FROM HFIR," relates to the activities associated with removing the cask from the HFIR bay area to a hot cell where target rod IR-75 (the failed target rod) could be removed from the cask. The fourth group of facts, "TARGET ROD RETRIEVAL AND ANALYSIS AND CASK RECOVERY," relates to the investigation of the rupture of target rod IR-75, the cleanup of the cask, removal of the cask from the hot cell, and efforts to return the cask to use. Within each group of facts, an attempt is made to present the relevant facts in chronological order, but because different actions were taking place at the same time, a precise chronology cannot be illustrated.

A visit was made by two Board members to INEL to become familiar with the manufacture, inspection, and documentation related to the target rods. Observations by the board members indicate the potential for introducing problems into the weld process. These observations include: (1) all of the weld procedure requirements are not followed in the welding process, (2) the purity of the shielding gas could not be determined, (3) the actual flow rate of the shielding gas could not be determined, (4) the materials used in the welding process are not fully controlled, and (5) the inspection methods used did not include radiographs.

Personnel at INEL stated that two failures of iridium targets have occurred at INEL. At least one of these is documented in an occurrence report, and this failure released a small amount of contamination.

\subsection{RECEIPT, HANDLING, AND IRRADIATION}

3.3.1 A letter dated May 25, 1993, from the INEL experiment project manager to the ORNL Iridium Project manager (Exhibit B) stated that target rod IR-75 and others were shipped during the week of May 25, and that target rod IR-75 conformed to specified requirements. 
3.3.2 The receipt, storage, and transfer of the target rods at ORNL is not documented, and there is no requirement to document them.

3.3.3 The material sample was not sent with the batch of target rods containing target rod IR-75. It was given directly to the IPDP manager at a seminar. He said he thought the sample was for demonstration rather than a test sample.

3.3.4 Fabrication work packages were not ser: with the target rods as agreed to in a meeting between ORNL and INEL personnel and as required by HFIR Experiment Safety Assessment ESA-HFIR-92-1 (Exhibit C). There is no formal documentation of the agreements contained in Appendix D of ESA-HFIR-92-1.

3.3.5 Chemical analysis and hardness testing required by ESA-HFIR-92-1 were not performed until after the event.

3.3.6 On June 10, 1993, the RRD Experiment Coordinator sent a letter to HFIR operations (Exhibit D) specifying that target rod IR-75 be placed in reactor position VXF 9, beginning with cycle 319. A letter from the Iridium Program manager was attached to this letter, and the Iridium Program manager letter also specified that target rod IR75 be placed in position VXF 9.

3.3.7 On June 11, 1993, target rod IR-75 was helium leak tested before and after a hydrostatic pressure test and oven bake. The helium leak test involves pressurizing the outside of the target rod with helium ( 8 psig for $12 \mathrm{~h}$ ), removing the helium atmosphere, placing the target rod in a vacuum, and looking for helium as an indication of a leak. The pressure test involves pressurizing the outside of the target rod with water, cycling the pressure between 500 and 1000 psi ten times, and then holding at $1000 \mathrm{psi}$ for 15 minutes. Immediately thereafter, the target rod is baked in an oven at $430^{\circ} \mathrm{F}$ for 1 hour.

The pressure test and oven bake were not specified by RRD and thus had no acceptance criteria associated with them. CTD, which was responsible for the testing, included the pressure test and oven bake to provide additional assurance of leak tightness, relying on swelling/rupture during the oven bake as evidence of waterlogging. The final helium leak test provides a check on the possible development of a leak during the pressure test and oven bake that did not result in significant waterlogging.

Prior to the target rods being shipped to ORNL, and in accordance with RRD specifications, INEL subjects the target rods to 700 psig external pressure (HFIR rupture-disc upper limit) using helium, after which a helium leak test is performed.

In addition to the leak test, the target rod was dimensionally checked and straightness tested. The drawing shows the minimum diameter of the target rod to be 0.475 inches 
and the maximum diameter to be 0.480 inches, with a straightness within 0.005 inches. However, the straightness gage allows a tolerance of 0.015 inches. The diameter of the target rod was measured twice during this test sequence, once at 0.474 inches and once at 0.471 inches.

3.3.8 Target rod IR-75 was delivered to the HFIR shift supervisor on Friday, June 11, 1993. The target rod remained at the HFIR site until Monday morning, June 14, 1993, when it was prepared to be loaded into the reactor.

3.3.9 The exact storage location of target rod IR-75 at the HFIR site during this time is unknown. Two shift supervisors said that they normally would put the target rod on a desk or in a drawer until it went into the reactor. No one said he could remember specifically what was done with target rod IR-75 between June 11 and June 14 .

3.3.10 On June 14, 1993, target rod IR-75 was placed in the can, loaded from the can into the tri-holder, and placed in storage in a rack in the reactor pool. This was done on shift between 12:01 a.m. and 8:00 a.m. Nothing abnormal was identified when loading the target rod. The target rod sat in storage in the reactor pool until June 15, 1993.

3.3.11 On June 15, 1993, the tri-holder containing target rod IR-75 was removed from storage and placed in position VXF 9 in the reactor. This was done about 3:00 a.m. Target rod IR-75 remained in position VXF 9 until September 5, 1993.

3.3.12 On August 31, 1993, the can and cable to be used for loading the target rods into the cask were installed in the cask at Building 3525. The inside of the cask had removable beta gamma contamination levels ranging from $200 \mathrm{dpm} / 100 \mathrm{~cm}^{2}$ to 1500 $\mathrm{dpm} / 100 \mathrm{~cm}^{2}$. These levels were within ORNL allowable limits. No alpha contamination was detected.

3.3.13 On September 2, 1993, prior to moving the cask to the HFIR site for loading the target rods, the outside of the cask was surveyed. The removable beta gamma contamination levels were less than $200 \mathrm{dpm}$, and the removable alpha contamination levels were less than $20 \mathrm{dpm}$. The external radiation levels were less than $2 \mathrm{mR} / \mathrm{h}$. The cask was transported to the HFIR bay area later on September 3, 1993.

3.3.14 Target rod IR-75 had been in HFIR for fuel cycles 319, 320, and 321. Fuel cycle 321 was terminated at 1:23 a.m. on September 4, 1993.

3.3.15 On September 5, 1993, after 5681 MWd of irradiation, the tri-holder containing target rod IR-75 was removed from position VXF 9 in the reactor and placed in storage rack B 8 in the reactor pool at 5:35 a.m. It remained in this storage location until September 7, 1993. 
3.3.16 On September 7, 1993, target rod IR-75 was removed from the tri-holder in rack B 8 and placed in position number 5 in the can. Target rods $38,39,72,73,74$, and 108 , which also contain iridium pellets, were also placed in the same can.

3.3.17 The 72-hour decay time for the target rods shipped after fuel cycle 321 was shorter than usual. The Iridium Program manager verified that the activity limits were acceptable for this shorter period in a letter to an Office of Operational Readiness and Facility Safety (ORFS) representative (Exhibit E). The ORFS representative concurred on August 24, 1993. (If the decay time is too short, the target rods could melt after being placed in the dry shipping cask.)

3.3.18 On September 7, 1993, between 3:00 a.m. and 4:00 a.m., the process of loading the cask was begun. The cask was loaded from the bottom. The rotary valve in the bottom section of the cask was opened, and the cask was lowered so that the bottom end extended several inches into the reactor pool water. The can containing seven target rods (with target rod IR-75 in position 5) was pulled up into the upper part of the cask, out of the pool water, and into the dry cask cavity. The rotary valve was then closed and the cask raised above the pool water to allow water to drain from the cask.

3.3.19 Water in the can drained through holes directly beneath each target rod and through holes in the side of the can. Drainage from the annulus between the target rod and tubular target-rod holder tends to be relatively slow, because the bottom end of the target rod covers the drain hole, even when the target rod is in an extreme lateral position. The water then drained through the clearance between the rotary valve and the surrounding portion of the cask.

3.3.20 The cask was rinsed with deionized water while suspended over the pool and allowed to drain. Radiation level measurements were taken immediately after the cask was raised above the pool; the levels were about $2 \mathrm{mR} / \mathrm{h}$ at contact below the cask. These levels were within limits and typical of past experience.

3.3.21 The cask was moved to the poolside Contamination Area where it was wiped down, and a complete radiological survey was performed. No levels exceeding ORNL criteria or indicative of abnormal conditions were detected.

3.3.22 The cask was then moved from the Contamination Area and placed on blotter paper in the reactor-bay area to await loading on a truck for transporting to the hot cell. About 45 minutes elapsed from the time the cask was raised above the water until it was placed on the blotter paper.

3.3.23 At that point the cask was sitting in a vertical position, but the cask is transported in a horizontal position. The cask was designed with an additional set of lifting lugs near the center of gravity so that it could be lifted and rotated to the horizontal position. 
3.3.24 Although the drawings for the cask show the presence of a bolted flange for closing the lower cask port, HFIR personnel said the flange is not used. Procedure RRD-TP-25, Revision 5, HRLEL 6-1/2" Carrier HFIR Underwater Loading Procedure, does not require that the bottom cover flange be installed, and it was not.

\subsection{EVENT}

3.4.1 The Plant and Equipment Division (P\&E) rigging crew arrived about 5:00 p.m. on September 7, 1993, to rotate the cask to the horizontal position and lift the cask to the bed of the transport truck. About 5:25 p.m., rigging was completed, and the health physics (HP) technician on duty performed a prelift survey. No abnormal radiological readings were noted, but the survey did not include the bottom of the cask, because the bottom was not accessible.

3.4.2 Until the time of the lift on September 7, 1993, all radiation and contamination surveys made in relation to moving the cask, which contained the target rods, from the HFIR site to the Irradiated Fuels Examination Laboratory hot cells were within the ORNL acceptable limits and consistent with past experience.

3.4.3 About 5:28 p.m., the riggers began to lift the cask slowly off the floor. The rigging was conducted per RRD Procedure RRD-TP-25, HRLEL 6-1/2" Carrier HFIR Underwater Loading Procedure. RRD-TP-25 did not meet all requirements of the DOE Hoisting and Rigging Manual in that it did not require P\&E riggers to be a part of the pre-lift briefing. Guidance to the P\&E riggers is general in nature, rather than detailing specific actions to be taken. When the cask was about 2 feet above the floor, the riggers began to rotate the cask from the vertical to the horizontal position. When the cask was rotated about 30 degrees from the vertical, the radiation alarms in the bay sounded. This was approximately 5:30 p.m. The alarms are located about 60 feet from the cask and alarm when they detect radiation levels above $22.5 \mathrm{mR} / \mathrm{h}$. When the radiation alarm sounded, it also annunciated in the reactor control room.

3.4.4 At the time the radiation alarms sounded, 11 people were in the reactor-bay area: two operators, two instrumentation and controls (I\&C) technicians, one truck driver, two $\mathrm{HP}$ technicians, three riggers, and one ironworker (the foreman for the transport crew). The two I\&C technicians were performing work that was unrelated to loading the cask on the truck.

3.4.5 When the radiation alarms sounded, the HP technician had a survey instrument and continuously monitored radiation levels in the area of the cask. Based on this, the rigger, one HF technician, and one operator remained in the bay to lay the cask down in a horizontal position on the floor. The other eight people left the area immediately. After the cask was laid in the horizontal position on the floor, the operator and the rigger left the bay area. The HP technician remained in the reactor bay to survey the cask. 
As the cask reached the floor in the horizontal position, a reactor shift supervisor (RSS) and another HP technician entered the bay area. The RSS determined that the horizontal position was unsafe, because radiation was possibly streaming from the bottom of the cask. The two HP technicians and the RSS moved the rigging cables from the middle lifting lugs and placed them on the top lifting lugs. The RSS used the crane to tilt the cask, keeping one edge of the cask on the floor, into a vertical position on the floor. The cask came to rest on blotter paper and one rigging cable that had been used earlier to allow access to the cable that raised and lowered the can in the cask. The HP technicians worked under the guidance of the RSS, who was fully trained and qualified to make the lift.

3.4.6 One HP technician took radiation readings and noted the following levels: about $5 \mathrm{R} / \mathrm{h}$ on contact at the center of the east side of the bottom portion of the cask; $3 \mathrm{R} / \mathrm{h}$ on the north side of the cask about 12 feet from the cask bottom; $3 \mathrm{R} / \mathrm{h}$ on contact at the top of the square bottom portion of the cask, and 1 to $2 \mathrm{R} / \mathrm{h}$ on contact at the top of the cask.

3.4.7 At 5:31 p.m., the HFIR operations manager activated the building evacuation alarm, and the RSS announced the evacuation of the building. When the building evacuation alarm was sounded, a signal was simultaneously sent to the laboratory shift superintendent and the emergency response plan was initiated.

The evacuation procedure requires that the building search team conduct a search of the building anytime the evacuation horn sounds. The search team consisted of the RSS and the three HP technicians. The RSS searched the bay area, one HP technician searched a heat exchanger cell where work was being done, one HP technician checked the hallways and area outside the reactor bay, and one HP technician searched the third-floor area of the building. No one was found in the building during the search.

3.4.8 The building was evacuated, and a personnel accountability survey was made. Two people were unaccounted for. Members of the local response emergency team reentered the HFIR building and searched the experiment room and adjacent office area for the two unaccounted for people. No one was found in the building during these searches.

The two people unaccounted for were contacted at their homes. One person had forgotten to "badge out" of the building, and the other person stated that the badge reader did not function properly upon badging out, but he did not report this to building operations personnel. General User Training requires that personnel "badge in" and "badge out". 
All personnel evacuated from the building were surveyed for contamination, and no contamination was detected. The results of this survey were not documented nor entered into the HP log.

3.4.9 The HFIR building evacuation and the personnel accountability activities were completed about 6:30 p.m.

3.4.10 The first action in trying to determine the scope of the situation was to verify the position of the latch handle on the rotary valve in the bottom of the cask. It was speculated that, if the latch handle had loosened, the rotary valve could rotate to an open position, allowing radiation to stream from the bottom of the cask.

The rotary valve in the bottom of the cask consists of a rotating cylinder that provides shielding when closed and has a transverse hole that can be aligned with the cask cavity to allow loading and unloading of a can. The valve is positioned by rotating a latch handle at the side of the cask. The latch handle can be rotated 90 degrees from the fully closed position (about 8 o'clock) to the fully open position (about 4 o'clock).

In 1992, the cask was modified to add a pin to lock the latch handle in the closed position to ensure the rotary valve would not rotate toward the open position while the cask was being handled.

About 7:00 p.m., several attempts were made to verify the position of the latch handle by using a remote camera. The position of the latch handle could not be conclusively determined.

3.4.11 At 7:45 p.m., an event critique was held. Notes from the critique are included as Exhibit F.

3.4.12 At 9:00 p.m., the RSS entered the control room with a hand-held radiation monitoring instrument. The RSS reviewed the status of plant systems and the instruments reading the radiation levels in the plant. Radiation levels were normal throughout the building except in the reactor-bay area and at the east window in the third-floor hallway outside the control room, where the readings were $3 \mathrm{mR} / \mathrm{h}$.

3.4.13 The DOE headquarters alternate for the primary contact was on site when the event occurred. This DOE representative was asked shortly after the event occurred (before 6:00 p.m. on September 7, 1993) how he wanted the initial phone report to be made. This DOE representative said the primary contact was not available until after 8:00 p.m. and to wait until then to initiate the phone bridge. The phone bridge was initiated at 8:15 p.m. and completed at 9:00 p.m. 
3.4.14 About 10:30 p.m., as a result of the critique, an HP technician entered the reactor-bay area with a survey meter and visually verified that the latch handle on the cask was in the closed position.

3.4.15 On September 8, 1993, at about 11:30 a.m., a radiation survey of some areas around the cask was conducted using a robot. This survey identified radiation levels of 500 $\mathrm{R} / \mathrm{h}$ on contact at one spot near the cask. As the distance from the cask increased to 3 feet, the radiation levels dropped to $0.5 \mathrm{R} / \mathrm{h}$. It was determined from the robot survey that personnel could enter the area to perform more detailed surveys.

One wheel on the robot was contaminated during the survey to a level of about 60,000 $\mathrm{dpm} / 100 \mathrm{~cm}^{2}$. One "particle" was removed using tape. The "particle" was analyzed and was determined to be iridium-192.

3.4.16 On September 8, 1993, at about 2:30 p.m., the radiation fields in the bay area were evaluated. Surveys were made with extended-probe radiation detectors to identify the sources and locations of these fields. High radiation levels that dropped off quickly were found, indicating that small, highly radioactive "particles" were present. The radiation levels near the "particles" changed with movement of the instrument so rapidly that it was difficult to determine their exact location and size.

3.4.17 About 5:00 p.m. on September 10, 1993, the truck that had been parked in the bay area to haul the loaded cask from the HFIR site to the hot cell was moved because it was in the radiation field and interfered with investigation and recovery efforts. The truck was equipped with air brakes, and it had to be moved before the air pressure bled off and locked the brakes. The truck brakes were released and the truck was towed out of the bay area using a tow motor. The truck was surveyed and returned to service.

3.4.18 On September 10,1993, at about 9:20 p.m., a thermal imaging camera was used to try to identify the number of sources and locations of the radiation readings. One discrete radioactive "particle" was located near one corner of the cask using the thermal imaging camera technique.

3.4.19 On September 11, 1993, at about 1:00 a.m., the "particle" was recovered by placing duct seal on the end of a tool about 10 feet long, moving the end around the area of the source, and picking the source up in the duct seal. The "particle" was then placed in a shielded container. The "particle" had a radiation reading of about $450 \mathrm{R} / \mathrm{h}$ at contact while it was lying on the floor. The actual recovery of the highest reading iridium "particles" resulted in 0.042 person-rem.

3.4.20 On September 11, 1993, at about 3:45 a.m., after the radiation field had been reduced by removing the radioactive "particle", the ventilation recirculation system in the reactor-bay area was shut off, the filters in both stationary air monitors located in the 
bay area were removed and replaced with new filters, and the radiation alarms were reset. The ventilation was not returned to service until the area was decontaminated.

Radioactivity was detected on filters from both stationary air monitors in the HFIR bay. The maximum amount was approximately $0.010 \mu \mathrm{Ci}$ and was analyzed to be iridium. The actual release mechanism and estimated concentration in air could not be determined. No radioactivity above background levels was detected from air samplers placed near the cask during recovery operations.

3.4.21 On September 11, 1993, at about 3:00 p.m., one equipment operator, one reactor operator, and two HP technicians went into the bay area to vacuum around and underneath the cask to remove as many loose "particles" as possible. The vacuum was located in a shielded box .

3.4.22 On September 11 and 12, 1993, a lead-lined pan was fabricated to fit on the bottom of the cask to provide shielding and thus minimize exposure during the recovery operations. Since the cask would now have to be transported in the vertical position, Building 3525 could not accommodate it. Therefore, it would be taken to Building 3047.

3.4.23 On September 13, 1993, at about 5:15 p.m., the cask was lifted up and placed in the lead-lined pan. As the cask was lifted, radiation levels in excess of $1000 \mathrm{R} / \mathrm{h}$ were measured underneath the cask. The floor area that had been underneath the cask was immediately vacuumed, and a forklift was used to place a piece of lead shielding on top of the area.

3.4.24 On September 14, 1993, at about 7:45 p.m., the lead shield was lifted using the forklift, and the area where the cask had been sitting was vacuumed by a technician. The blotter paper and choker were placed in a shielded box by the robot, and the lead shield was replaced.

3.4.25 On September 15, 1993, at about 3:00 a.m., a survey to locate the remaining sources of radiation was done. A highly collimated gamma detector with an aligned laser attached to the collimator was used. This survey was made from the third floor, the floor above the bay, and no entry into the bay radiation fields was required. When the maximum count rate on the spectrometer was obtained, the laser was turned on and the location of the radiation source was identified.

The lead shielding on the forklift that had been placed on the floor over the area where the cask had been sitting was lifted. The radioactive "particles" not picked up by the vacuuming done earlier were picked up with a vacuum cleaner and placed in the shielded container. 
3.4.26 Twenty Radiation Work Permits (RWP) were written to control work performed at the HFIR site after the initial evacuation. Thirty-seven persons made 70 entries under these RWPs.

The following table summarizes the personnel radiation exposures for the iridium contamination event. The term "release" means activities up to and including the reentry by the HP technician to verify the latch position. The term "recovery" means all those activities covered by RWPs at the HFIR site and the transportation of the cask to the Building 3047 hot cells. The term "3047" applies to all events at Building 3047 until the cask was placed in the hot cell. The units of collective exposure are person-rem, the other units are rem.

Table 3.1

$\begin{array}{lclc} & \text { collective } & \text { high } & \text { average } \\ \text { release } & 0.198 & 0.055 & 0.013 \\ \text { recovery } & 0.512 & 0.240^{*} & 0.014 \\ 3047 & 0.011 & 0.002 & 0.001\end{array}$

TOTAL*

$1.144^{*}$

*NOTE: Entries marked with an asterisk are established using thermoluminescent dosimeter (TLD) readings and taking supplemental dosimetry into account, so the total is not necessarily a sum of the other entries, which were obtained from direct-reading dosimeter (DRD) readings.

Most of the collective exposure during the "recovery" was incurred by two persons during one operation: removing the blotter paper and choker from the cask area. These two persons incurred a collective exposure of 0.305 person-rem according to DRD readings. (A robot was also used during this work.) All workers were within laboratory administrative limits and met ALARA goals. The collective exposure was about 20 percent of the DOE annual limit for ai. . idividual, and about half the ORNL annual ALARA goal for an individual.

3.4.27 Thirteen individuals received whole-body counts in an attempt to detect internally deposited iridium. All results were less than the minimum detectable activity for iridium. Administrative approvals existed for all recovery operations.

3.4.28 Daily planning sessions wee held with health physics personnel, managers, ALARA staff, engineers, and DOE personnel. These planning sessions determined what the 
next day's activities were to be, the physical and administrative controls, and the exposure limits.

3.4.29 During the event, information supplied to DOE Headquarters personnel was often supplied outside of the normal channels of communication. Information was requested by many different people. Because conditions were constantly changing, as "informal" updated information was supplied, the "formally" transmitted information sometimes appeared erroneous. This precipitated even nore "informal" information requests, resulting in almost a total breakdown of the "formal" communications channel.

\subsection{PLANNING, CLEANUP, AND CASK REMOVAL FROM HFIR}

3.5.1 An ALARA plan (Exhibit G) to remove the cask from the HFIR bay and transport it to a hot cell was approved on September 30,1993. The plan included dosimetry requirements, expected dose rates and exposures, and access controls to maintain the exposures within the plan estimates. The estimated collective exposure was 0.216 person-rem. The actual collective exposure was 0.011 person-rem, or about 5 percent of the plan estimate.

3.5.2 Mockups were used to simulate a transportation "dry-run" prior to the transport of the cask. A "dry-run" document (Exhibit H) was generated on September 28, 1993, and a similar empty cask was used to approximate unloading and placing the cask in the hot cell. This allowed the specially-built trolley and other special tools to be tested prior to handling the actual cask.

3.5.3 On October 3, 1993, the cask and the lead-lined pan were moved to the hot cell at Building 3047 for removal of the target rods and cask recovery.

3.5.4 The air sample taken during Building 3047 operations had no detectable radioactivity levels above background detected.

\subsection{TARGET ROD RETRIEVAL AND ANALYSIS AND CASK RECOVERY}

3.6.1 At Building 3047, the shield plug was removed from the cask to reveal the upper end of the can containing seven target rods.

3.6.2 Several iridium pellets and small pieces of dark fluffy material were on top of the can.

3.6.3 After removing the locking ring from the top of the can, more pellets were found on top of the can.

3.6.4 Smears were taken from the upper end of the can at the location of each target rod, and the activities indicated that position 5 contained a ruptured target rod. Position 5 contained target rod IR-75. 
3.6.5 Removal of the seven target rods from the can revealed a rupture in target rod IR-75 but not in any of the others. The rupture was oriented longitudinally. It was about 1 inch long, and the center was about 1.5 inches from the upper end of the target rod. The maximum lateral opening was about 0.2 inches.

3.6.6 Visual inspection revealed that at least ten pellets were missing from target rod IR-75, and more were deliberately shaken out during the recovery process. Further, a white, powdery deposit was on the inside surfaces of the target rod.

3.6.7 A portion of the weld on the upper end of target rod IR-75 appeared to have a "whisker" embedded in it. The weld area varied in color from black to shiny, and there was a depression near the leak site.

3.6.8 A leakage path through the upper-end weld was discovered by pressurizing the interior void space in the target rod with nitrogen gas through the rupture and submerging the target rod in water. With 15-psi differential pressure, there were no bubbles, but with $30 \mathrm{psi}$, bubbles emanated from a location in the weld at the upper end. There were no other indications of leaks, even at 60 psi.

3.6.9 The leak was in the vicinity of the "whisker." It could not be determined whether the "whisker" contributed to the development of the leakage path.

3.6.10 The swelling of the sheath in the vicinity of the rupture was not uniform around the sheath but increased going from the backside of the target rod to the longitudinal centerline of the rupture.

3.6.11 After the leak site was located, target rod IR-75 was moved to a hot cell in Building 3525 , where metallographic analysis was performed.

3.6.12 Radiographs of six unirradiated target rods revealed lack of fusion in the welds on two of the target rods. Radiographs of the cutoff ends of target rod IR-75 were of relatively poor quality and were inconclusive. 

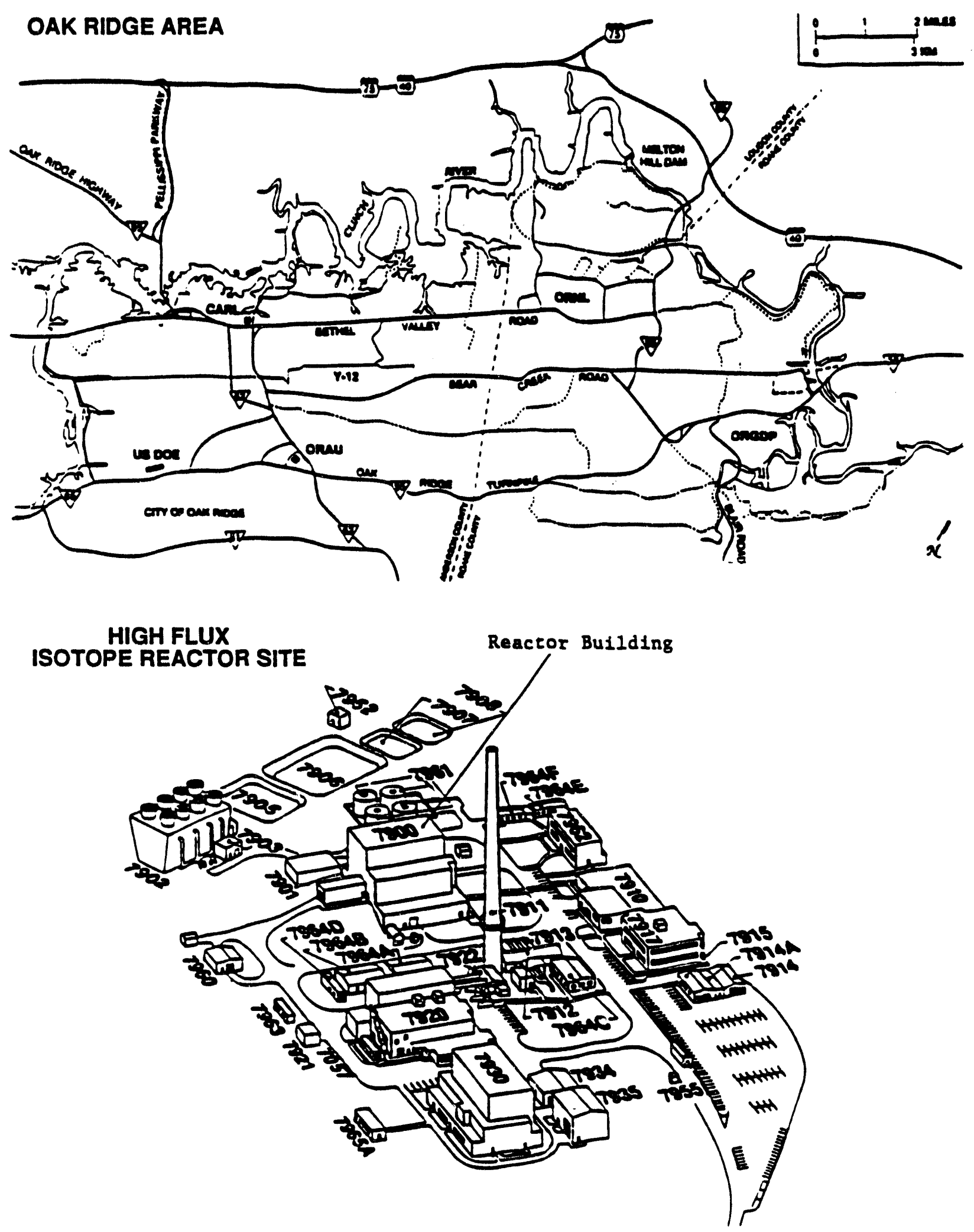

Fig. 3.1. Map of Oak Ridge area and the HFIR site. 


\section{ANALYSIS}

\subsection{SUMMARY}

On September 7, 1993, at about 4:30 a.m., seven iridium target rods, located in a can, were placed in a cask at the HFIR site. Subsequently, the cask was moved to the reactorbay floor beside the pool. About 13 hours later, the cask was raised and tilted in preparation for loading on a transfer truck. During the tilting operation, the building area radiation alarms sounded, indicating that radioactive material had been released from the cask and thus that one or more target rods had failed. Subsequently, more precise measurements of activity indicated that one or more iridium "particles" had escaped the cask, further indicating failure of one or more target rods.

The cask was transferred to a hot cell, and it was eventually determined that one of the target rods had experienced rupture of the sheath (Fig. 4.1), and that several iridium pellets had been ejected through the rupture. The investigation revealed that the rupture was the result of expansion of water and steam in the void space in the target rod. The water entered the target rod through a defect in the weld at the upper end of the target rod while the target rod was being subjected to external water pressure in the reactor. The rupture occurred after the target rod was placed in the cask, where the complete absence of cooling water resulted in calculated target rod temperatures high enough to cause sufficient internal steam pressure to result in rupture. While the target rod was in the reactor and reactor pool, the calculated temperatures of the target rod were low enough to prevent rupture.

Problems noted in the target-rod manufacturing process could have reasonably affected weld quality, but none of these problems could definitely be established as a direct cause of the weld failure.

The Events and Causal Factors Chart is shown in Appendix B.

\subsection{RECEIPT, HANDLING, AND IRRADIATION}

This portion of the analysis addresses the management systems that control the Iridium Program at ORNL. Requirements for the Iridium Program are generated by INEL, the Chemical Technology Division, and the Research Reactors Division. Additionally, testing of the target rods is done by the Health and Safety Research Division's Nuclear Medicine Group.

The lack of written instructions and detailed documentation describing management of the target rods resulted in some difficulty in determining the events in the life of target rod IR-75 at ORNL. There are no instructions pertaining to the receipt of target rods, no documentation of the receipt of target rods, and no requirement to have these instructions. There are no procedures that describe the storage of target rods at the HFIR site prior to 
irradiation. The exact location of target rod IR-75 between June 11 and June 14, 1993, could not be determined, but target rods are normally kept on a desk or in a drawer until they are placed in the reactor.

Additionally, operating procedures for handling the target rods and tri-holders and for positioning them in HFIR did not specifically address the target rods and tri-holders used. A procedure for removable beryllium (a position in the reactor) quadholders is used, but these are not the same target rods and not the same position in the reactor.

Narrative logs kept at the HFIR site contained entries such as "Completed iridium moves" and "completed target rod bundle work per shutdown schedule" but do not describe what was actually done.

Documents defining requirements for the program were not always signed in the indicated places before use to document management awareness and acceptance of those requirements. Experiment Safety Assessment, ESA-HFIR-92-1 was not signed by the Office of Operational Readiness and Facility Safety representative. However, a letter was issued by this office approving the assessment. Additionally, Attachment D of this same assessment, "Fabrication Requirements for Iridium Irradiation Capsules Fabricated at INEL and Irradiated at ORNL," was not signed as accepted by any of the eight reviewers. The handwritten version was signed.

Fabrication work packages, which include material manufacturer's heat numbers and material samples for each batch of material, were to be shipped with the target rods, but this was not done for target rod IR-75. The sample was given to the IPDP manager at a seminar rather than shipped with the target rod. The manager thought the test sample was for demonstration, and thus the sample was not tested for hardness and chemical composition as required until after the event. When tested, the sample passed the required tests.

ORNL target-rod test criteria were compared with test documentation. Target rod IR-75 was required to have a minimum diameter of 0.475 inches. Target rod IR-75 was actually measured twice at 0.474 and 0.471 inches, both less than the minimum acceptable diameter. Acceptance of target rod IR-75 was on the basis of acceptable helium leak-test results.

The specification for making measurements of the diameter of the target rod does not include the weld areas. These areas are the most likely to be undersized because they are hand filed to remove excess weld material. Typical cross sections of the ends of target rods indicate the ends are tapered after filing, resulting in an undersized diameter in the weld area at the end of the sheath. This increases the chances of a defect in the weld extending from the annulus between the sheath and the core to the outer surface of the target rod and becoming a leakage path. 
During early discussions between ORNL and INEL about processing iridium at ORNL, INEL offered the use of a sealed can to hold the target rods inside the cask, but ORNL declined this offer. Experiment Safety Assessment ESA-HFIR-92-1, Irradiation of INEL Iridium Targets in the HFIR SVXF, was performed prior to the iridium program returning to ORNL. However, no specific document exists that rejects the INEL sealed target-rod container. The reusable INEL container was not used because there was a concern that a reusable container could be a potential source of contamination (from the hot cells) of the HFIR pool. Because the rotary valve is designed with a clearance between the valve and the cask, this decision left the target-rod sheath and weld as the only barriers between the iridium pellets and the outside of the cask. Target-rod failures have occurred, and that is one reason INEL used the sealed can.

\subsection{EVENT}

The event was initiated when area radiation alarms sounded during the attempt to load the cask on a truck for transport to the hot cells. When the radiation alarms sounded, all personnel in the HFIR bay immediately evacuated except one rigger, one HP technician, and one reactor operator who remained long enough to lower the cask to the floor in a horizontal position. The rigger and reactor operator then left the bay area. As the cask reached the floor, the RSS and a different HP technician entered the bay. The RSS was concerned that the rotary valve in the bottom of the cask had partially opened, reducing the shielding and allowing radiation to stream out of the cask. The RSS and two HP technicians then moved the cask to the vertical position keeping it close to the floor, so the beams of radiation would be shielded by the floor. Then they evacuated the bay.

The next actions were to evacuate the building and account for personnel. When the reactor-bay radiation alarms sounded, the operations manager was in a room adjacent to the control room and was working on other aspects of reactor operations. He noted that personnel radiation monitors stored in the control room were sounding, noted personnel evacuating the bay, and sounded the building evacuation alarm within one minute of the reactor-bay alarms. This action automatically initiated the HFIR emergency response plan. The building was searched. No one was found, and personnel assembled at the assembly point and were surveyed for radioactive contamination; none was detected.

Two personnel were unaccounted for after the building was evacuated, and the areas where these personnel had been were searched; no one was found. One person was located at home almost immediately, and one was located at home about 45 minutes later. One person said he had forgotten to "badge out" of the personnel accountability system when leaving as required. The other said iils badge did not work in the badge reader, but he did not report this to build. $1 \mathrm{~g}$ operations personnel. 
The collective exposure for the event listed in Table 3.1 consists of 0.138 person-rem for the evacuation and an additional 0.060 person-rem for searching the building. There was a truck driver in the bay at the time of the initial alarm who did not have a DRD, but his TLD was read, and his exposure was zero. These exposure levels indicate that the emergency plan and actions of personnel were effective in minimizing exposure.

The Board made extensive efforts to determine if there were indications prior to the event that could or should have alerted personnel to abnormal conditions. It was determined that there were no indications that could have reasonably alerted personnel to the target-rod rupture in the cask. An additional radiological survey, which was not required, was done immediately prior to lifting the cask, although the bottom was not accessible. This survey detected no abnormal conditions.

\subsection{TECHNICAL EVALUATION}

\subsubsection{Description of Target Rod}

The target rod that failed is designated IR-75. As indicated in Fig. 4.2, it is made up of two pieces of 6061-T6 aluminum tubing: the core, which has the pellets inset in shallow recesses in the outer surface, and an outer sheath that retains the pellets and is attached to the core by circumferential welds at either end. As a result of the welding process, the T6 high-strength condition is not retained over the full length of the assembly. The strength is less toward the welds, and this reduced strength may extend as much as 2 inches from the weld (based on calculated temperatures during welding), which is where the rupture occurred.

\subsubsection{Inspection}

Target rod IR-75 was inspected on three separate occasions for leakage using a helium leak-test procedure. One test was made at INEL following fabrication, and two tests were done at ORNL. The two tests at ORNL were done during the same testing sequence in preparation for placing the target rod in HFIR. The target rod was helium leak-tested, pressure-tested, and again helium leak-tested during the test sequence. The target rod passed the helium leak tests.

\subsubsection{Irradiation History}

Target rod IR-75 was irradiated in HFIR for three consecutive fuel cycles (cycles 319 , 320, and 321); the last cycle ended on September 4, 1993. It was then stored in the pool until September 7, 1993, when it was moved into the shipping cask. 
The cask (Figs. 4.3 and 4.4) was loaded from the bottom, after the rotary valve in the bottom section of the cask was opened, and after the cask was lowered so that the bottom end extended several inches into the reactor pool water. The can (Fig. 4.5), containing seven target rods, with target rod IR-75 in position 5 (Fig. 4.6), was pulled up into the upper part of the cask (Fig. 4.4) into a dry cavity. Water in the can drained through holes directly beneath each target rod and through holes in the side of the can. Drainage from the annulus between the target rod and tubular target-rod holder (Fig. 4.5) tends to be relatively slow because the bottom end of the target rod covers the drain hole even when the target rod is in an extreme lateral position. If the target rod is tilted or the end of the target rod is uneven (weld variability), the drainage rate tends to be enhanced. The drainage time is also influenced by the time required to raise the can out of the pool up into the dry cavity in the cask.

The rate at which the can drains is a factor because it influences the local heat-up rate of the target rod and thus the longitudinal variation in temperature and thus strength of the target-rod sheath. Because the upper portion of the target rod dries out first, it will be at the highest temperature during the drainage process.

After, and as, the water level recedes, natural convection of air tends to maintain a higher temperature in the upper portion of the target rod. However, the longitudinal cosine distribution of the decay-heat power distribution tends to result in a maximum temperature at midlength. The net result is a maximum temperature somewhat above midlength.

Calculation of the target rod temperatures while the target rod is in the cask is difficult because of the complex geometry and the uncertainty in the heat generation rate and heat transfer coefficients. Heat is transferred to the cask mainly by radiation, and the emissivities of the several different surfaces are not known very well. A best-estimate analysis (Ref. 1) indicates a maximum target-rod temperature of $\sim 840^{\circ} \mathrm{F}$, while a $+2 \sigma$ (two standard deviations) value is close to the melting point (there is no physical evidence that melting took place). The time for the target rod to achieve the maximum temperature is $\sim 10$ minutes (Ref. 2), which is substantially longer than the drainage time but less than the time that the cask remained suspended over the reactor pool ( $\sim 15$ minutes). Thus, timewise, it is possible that rupture of target rod IR-75 took place while the cask was over the pool. There is no indication that pellets fell into the pool. However, it cannot be totally ruled out.

There was no indication of unusual radiation dose rates associated with the target rods before and shortly after they were placed in the cask. After the cask was loaded and the cask valve closed, the cask was moved to the reactor-bay floor adjacent to the pool. There was still no indication of unusual radiation dose rates on the outside of the cask. In preparation for loading the cask on the transfer truck, the cask was raised off the floor and tilted to a horizontal position. During the tilting operation, the radiation monitors alarmed. The cask was returned to an upright position, and subsequent local monitoring indicated that one or more iridium "particles" had been released from the cask. From this, it was apparent that one or more target rods had failed. 
Eventually, the cask was placed in a lead-lined pan and taken to a hot cell in Building 3047.

\subsubsection{Hot-Cell Examinations (Building 3047)}

Upon opening the top of the cask, several pellets and small pieces of a dark fluffy material were found on top of the can (Fig. 4.7). After removing the can from the cask and then removing the locking ring at the top of the can, several more pellets were found. Smears were taken from the upper end of each target-rod holder tube and counted for radioactivity. The count rates indicated that the target rod in position 5 (Fig. 4.6) had ruptured. The target rod in this position was IR-75. Subsequent removal of the target rods from the can, and a close visual inspection, confirmed that target rod IR-75 was the only target rod that had failed.

The specific failure of target rod IR-75 was a 1-inch-long, longitudinally oriented rupture of the target-rod sheath, with the center of the rupture being $\sim 1.5$ inches from the weld at the upper end (Figs. 4.1 and 4.8). The maximum opening in the sheath was $\sim 0.2$ inches, large enough to observe that at least ten pellets were missing (Fig. 4.8).

The large size of the rupture in the target-rod sheath indicated that the rupture was the result of high internal pressure and the expansion of steam. A search was made for a leak that would allow water to enter the void space in the target rod.

A visual inspection of the target rod did not positively reveal a leak site, although there was_suspect porosity on the surface of the welds. Thus, internal pressure was applied with nitrogen gas, through a fitting applied over the rupture (Fig. 4.9) with the exposed areas of the target rod placed under water. With 15-psi differential pressure, there were no bubbles, but with 30 psi, bubbles emanated from a location in the weld at the upper end (Fig. 4.10). There were no additional indications of leaks, even at $60 \mathrm{psi}$.

The visual inspection of the target rod did reveal some interesting features: (1) a "whisker" appeared to be embedded in the weld at the upper end close to the location of the leak site (Fig. 4.11); (2) the weld area varied in color from black to shiny, and there was a depression near the leak site (Fig. 4.11); and (3) the swelling of the sheath in the vicinity of the rupture was not uniform around the sheath but increased going from the backside of the target rod to the longitudinal centerline of the rupture (Fig. 4.12). This latter feature is the consequence of azimuthal variations in dimensions or properties that result in local necking down of the wall, followed by reduced local resistance to swelling as the wall thins further and the radius of curvature increases locally. 
Another observation was that there was a white, powdery material inside the target rod [observed through rupture opening in the sheath, (Fig. 4.8)].

Following these observations and tests, the target rods were moved to a hot cell in Building 3525 , where additional operations and observations could be made. See Section 4.4 .7 for radiography results.

\subsubsection{Hot-Cell Examinations (Building 3525)}

The first major operation in Building 3525 was to cut off both ends of the target rod at the usual cutoff location [ 0.4 inches from the end, (Figs. 4.2 and 4.13)]. The cut surface (plane A, Fig. 4.13) was polished, and then the wall thickness of the sheath was checked (Fig. 4.14). The wall thickness appeared to be reasonably uniform. (The design drawing does not specify tolerances on concentricity of inner and outer surfaces. The dimensional tolerance on wall thickness, assuming concentricity, is \pm 0.005 in.)

After the ends of the target rod were removed, the sheath over the remaining section was removed and the remaining pellets recovered. It was observed that all interior surfaces, including the pellet surfaces, had a light coating of a tightly adhering, white, powdery material. A sample large enough to identify the material could not be obtained, but a visual examination and knowledge of temperatures and materials indicated that the white powdery material was aluminum oxide generated in the presence of water and at elevated temperature (Ref. 3). There was no indication that the dark, fluffy material observed on the upper end of the can had been inside the target rod (none was found inside the target rod), and thus no attempt was made to identify it.

In an effort to learn more about the apparent leakage path and the whisker in the weld, the cutoff end from the upper end of the target rod was cut in half, using a longitudinal cut (Fig. 4.13, second cut), with the leakage site at $\sim 90^{\circ}$ to the cutting plane (plane B). The two pieces were potted, and the outer surface (opposite from cutting plane $B$ ) of the piece with the leak site was polished in a direction normal to cutting plane B (Fig. 4.13). This was done in an effort to trace the whisker and leakage path. Polishing revealed a small hole (Fig. 4.15) that extended radially inward from the outer surface to the annulus between the core and sheath.

As polishing proceeded, some indications of holes vanished and new ones appeared (comparison of Figs. 4.15 and 4.16). Finally, a relatively large triangular opening developed (Fig. 4.17). The triangular shape indicated that a rather large cavity beneath the outer surface was connected with the annulus and created a thin spot in the sheath or weld where the leakage path extended to the outer surface. 
The view through the triangular hole is of the outer surface of the core (circumferential machining marks are visible), indicating that the weld metal directly above, containing the large cavity and leakage path, was not fused to the core at this location. It is possible that thermal expansion of trapped air in the annulus or outgassing of a foreign substance in this area during welding resulted in the large cavity and prevented fusion with the core. It is also possible that the triangular opening is the result of a chamfer on the inside corner of the end of the sheath (the result of deburring). This latter feature would be consistent with the existence of the unfused area but requires that the leakage path be at least partially in a location that should contain base material.

The view through the triangular hole also revealed a fiberlike foreign material in the cavity or annulus (Figs. 4.17 and 4.18). It is not known what this material is, but it could be one or more of the following: (1) an extension of the whisker (Fig. 4.11); (2) something introduced with the potting material (the cavity and annulus are full of potting material, which contains some bubbles); or (3) a foreign material, aside from the whisker, that was introduced during fabrication. No further efforts to identify the fiberlike material and whisker are planned.

Following the above evaluation of the leakage path, a recent report (Ref. 4) became available that contained evidence of similar large subsurface cavities in other iridium target rods. Thus, target rod IR-75 does not represent an isolated case.

Cutting plane B (Fig. 4.13) on the potted piece without the leak site was polished to show the cross section of the weld (Fig. 4.19). Some porosity was detected (Fig. 4.20 ), but at this particular location ( $90^{\circ}$ from leak site) there is no evidence of a nonbond or cavity at the end of the sheath or of a chamfer on the inner corner of the sheath. There is, however, an unfused interface between the inner surface of the sheath and outer surface of the core at the end of the narrower of the two clearances shown (Fig. 4.19).

\subsubsection{Radiographs of Typical Target Rods}

Radiographs of the target rods are made routinely to check on the number of pellets prior to welding. These radiographs do not, however, reveal useful information about the welds, and no other radiographs are specified because the design of the weld joint presumably does not lend itself well to radiography. Even so, as a part of this investigation, radiographs were made of six typical unirradiated target rods and also of the cutoff ends of target rod IR-75, with the intent of looking for defects in the welds. Unbonded interfaces were found at the ends of the sheaths of two of the typical target rods (Fig. 4.21), but apparently the nonbond did not extend completely through the welds because the target rods passed the helium leak tests. Radiographs of target rod IR-75 were not of sufficient quality to reveal any porosity or nonbonds. 


\subsubsection{Cause of Failure}

The failure of the target rod appears, on the basis of the foregoing information, to be the result of water leakage into the target rod through a high-resistance flow path, followed by heating of the target rod to a high enough temperature to result in internal pressure sufficient to rupture the sheath. The more important pieces of evidence that support this conclusion are

1. a high-resistance leakage path;

2. a coating of what is presumed to be aluminum oxide on the pellets, indicating the presence of water;

3. high calculated temperatures in the target rod while in the shipping cask; and

4. the large opening of the rupture, which indicates a substantial expansion of a fluid, such as water.

The pressure required for failure of the target-rod sheath can be estimated from (see Appendix D)

$$
p=\frac{t \sigma}{a},
$$

where

$$
\begin{aligned}
& a=\text { radius of sheath }=0.215 \mathrm{in} . \\
& \mathrm{t}=\text { wall thickness }=0.0275 \mathrm{in} . \\
& \sigma=\text { ultimate strength. }
\end{aligned}
$$

The ultimate strength of the material depends on the temperature, radiation effects, and the temperature achieved in the sheath during the welding process (annealing effect). Above $400^{\circ} \mathrm{F}$, the ultimate strength of 6061 is about the same for the T6 and T4 conditions (Ref. 5). If it is assumed that radiation effects compensate for annealing effects associated with the welding process, then the critical temperature for failure of the target-rod sheath is $\sim 600^{\circ} \mathrm{F}$. The corresponding pressure and stress are $1500 \mathrm{psi}$ and 10,000 psi, respectively. (If radiation does not compensate for annealing, the calculated critical temperature is less.) The calculated best-estimate, maximum temperature of the target rod while in the cask is $\sim 840^{\circ} \mathrm{F}$, and this would be achieved in about 10 minutes after the can containing the target rods is pulled up into the cask. This indicates, with adequate margin for error, that the critical temperature was achieved, and that the failure occurred well before the detected release of radioactive material from the cask.

The location of the rupture along the length of the target rod is not a critical item for this investigation, but it is of some interest. While the target rod is in the cask, the upper end of the target rod tends to be at a higher temperature than the bottom. This 
is because of the time required for water to drain from the can shortly after the can is pulled into the cask and because of the natural convection of air in the can during and after the drainage. Counteracting this to some extent is the cosine distribution of the neutron flux during irradiation of the target rods, which tends to result in a maximum power density and thus temperature at midlength. The net effect is a maximum temperature above midlength.

As mentioned previously, temperature affects the strength of the material both directly and indirectly. The indirect effect is associated with annealing, and some annealing could take place during welding and also during the temperature transient while the target rod is in the cask. Calculations indicate that during welding, temperatures above $1000^{\circ} \mathrm{F}$ extend at least 2 inches from the end of the target rod (see Appendix E). Significant annealing takes place above $775^{\circ} \mathrm{F}$ (Ref. 5), but the time at temperature is important. The time during welding is short relative to normal annealing times. Even so, it is expected that significant annealing takes place, but the amount tapers off along the length of the target rod (Ref. 6).

Another factor affecting the location of the failure is the mechanical constraint at the weld, but according to calculations, this effect extends only about 0.3 inches from the weld (see Appendix F).

The net calculated effect of temperature, radiation, annealing, and constraint gradients indicates a failure location closer to the end of the target rod than observed, although there is considerable uncertainty in the estimate. In this regard, it is of interest to note that unirradiated target rods hydro tested to failure at uniform temperature $\left(\sim 70^{\circ} \mathrm{F}\right)$ failed in about the same location (Ref. 2). This indicates that the competing effects of constraint and annealing during welding dictate the location, but it is not known why the location is so far from the end where annealing presumably has its greatest effect.

\subsubsection{Summary}

All of the data and the analyses indicate that target rod IR-75 had a small leakage path in the weld at the upper end while being irradiated in HFIR. The elevated pressure $(\sim 500 \mathrm{psi})$ in HFIR forced water into the void space within the target rod. After transfer of the target rods to the shipping cask, the elevated temperature $\left(\sim 840^{\circ} \mathrm{F}\right.$ max $)$ of the target rod resulted in generation of high-pressure steam within the target rod. Rupture of the target-rod sheath occurred at a pressure of $1500 \mathrm{psi}$ or less. The steam-driven rupture caused a large enough opening in the sheath for ejection of several pellets. One or more of the ejected pellets fell through the clearance between the can and cask to the top of the rotary valve in the bottom of the cask. Upon tilting of the cask, the "particles" passed through the clearance between the rotary valve and the surrounding portion of the cask, exiting the cask. 
According to inspection records, target rod IR-75 was subjected to three helium leak tests without indications of a leak. Therefore, it must be that the leakage path was completed following the final helium leak test, perhaps as a result of thermal loading in HFIR.

\subsection{HFIR RECOVERY}

The recovery consisted of retrieving and shielding the iridium "particles" that fell out of the cask, decontaminating the bay area, and transporting the cask to Building 3047. The retrieval and shielding of the "particles" was controlled by Radiation Work Permits and detailed work instruction sheets. Collective radiation exposure of 1.13) person-rem for HFIR operations is considered acceptable and is evidence that work planning and radiological controls were also acceptable. Exposure-reducing techniques, such as remote handling techniques, thermal imaging, and collimated radiation detectors to locate the iridium "particles," were used.

Robotics were also used, and personnel were interviewed concerning the effectiveness of the robotics in reducing exposures. Most health physics personnel were of the opinion that the robot was ineffective in reducing exposures, but no precise determination could be made, because there is no similar operation available for comparison.

\subsection{CASK RECOVERY}

A transportation plan was generated for moving the cask from the HFIR site to the Building 3047 hot-cell facility. This plan included a transportation plan, a tie-down plan, a critical lift plan, personnel access controls along the route while the cask was being transported, and a safety assessment for an event in which radioactive material is released.

Mockups for the transportation plan were used to test the plan, equipment, and special tools built for handling the cask. A similar cask was used to simulate the lift at the hot cells, to test the specially-built trolley used to load the cask into the cells, and to trouble-shoot the procedures. No significant problems were encountered during the actual handling of the loaded cask, and collective personnel radiation exposures were only 0.011 person-rem.

An ALARA plan was generated to manage the cask at Buildir. 3047 . This plan described personnel access controls, estimated exposure times and radiation exposure rates, specified dosimetry requirements, and established exposure goals. The personnel exposures were well within these goals, indicating the adequacy of the plan.

The recovery of the cask, the only major piece of equipment, continues at the time of this report. The personnel radiation exposures, time, and technical difficulties in 
restoring the cask to service are likely to be comparable to the operations involved in recovering the loose "particles" and placing the cask in the cell. A few pellets from target rod IR-75 are still in the cask, and these pellets must be recovered before the cask can be used.

\subsection{PRODUCT RECOVERY}

The pellets in the six intact target rods and most of those in target rod IR-75 were processed and accepted by the customers. The total number of pellets loaded into target rod IR-75 was 726, and the number thus far recovered is 713. One or more are in a shielded container at Building 7910 , and some remain in the shipping cask. The latter are scheduled for recovery by March 31, 1994.

\section{References}

1. A. L. Longest, ORNL, Thermal Analysis for Iridium Transport Cask after Removal from HFIR Pool on September 7, 1993, letter to R. D. Cheverton, ORNL, November 10, 1993.

2. Personal communication with J. Brasier, INEL, regarding measurement of target-rod temperature and hydro-testing of unirradiated target rods.

3. Personal communication with G. L. Copeland, ORNL, December 3, 1993.

4. J. C. Downey, Fusion-Weld-Joint Design Modification for 6061-T6 Aluminum Thin-to-Thick-Walled Tubing in Irradiated Capsules, EG\&G Idaho Inc., Internal Technical Report PG-T-93-027, November 15, 1993.

5. Aerospace Structural Metals Handbook, AFML-TR-68-115, 1979

6. Personal communication with K. Farrell, ORNL. 


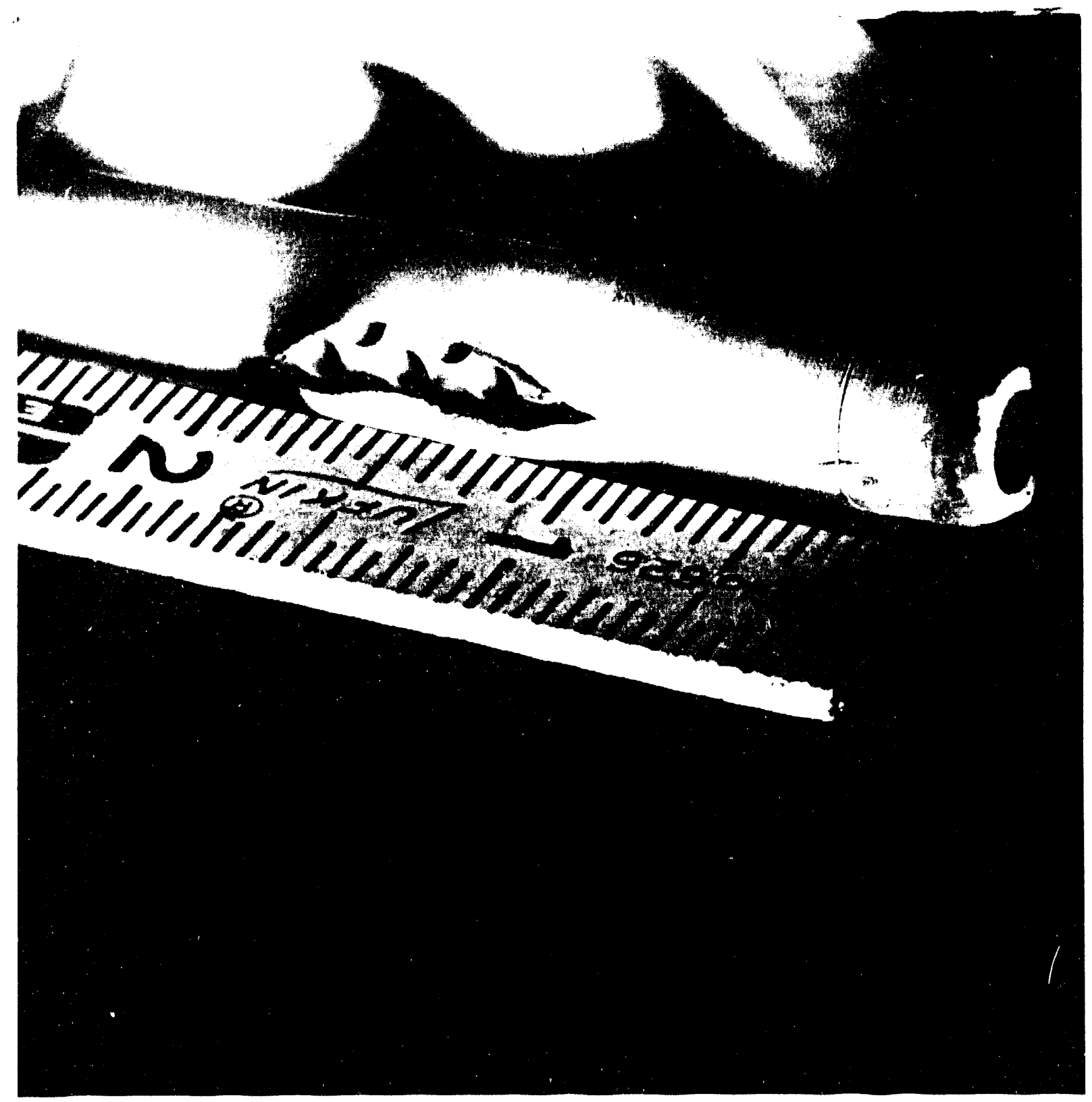

Fig. 4.1. Rupture in upper end of iridium target rod IR-75. 


\section{○}

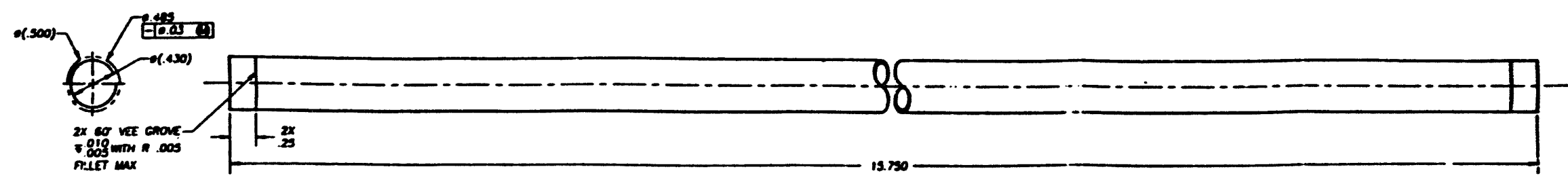

Sheath

(G) оетан $\triangle$
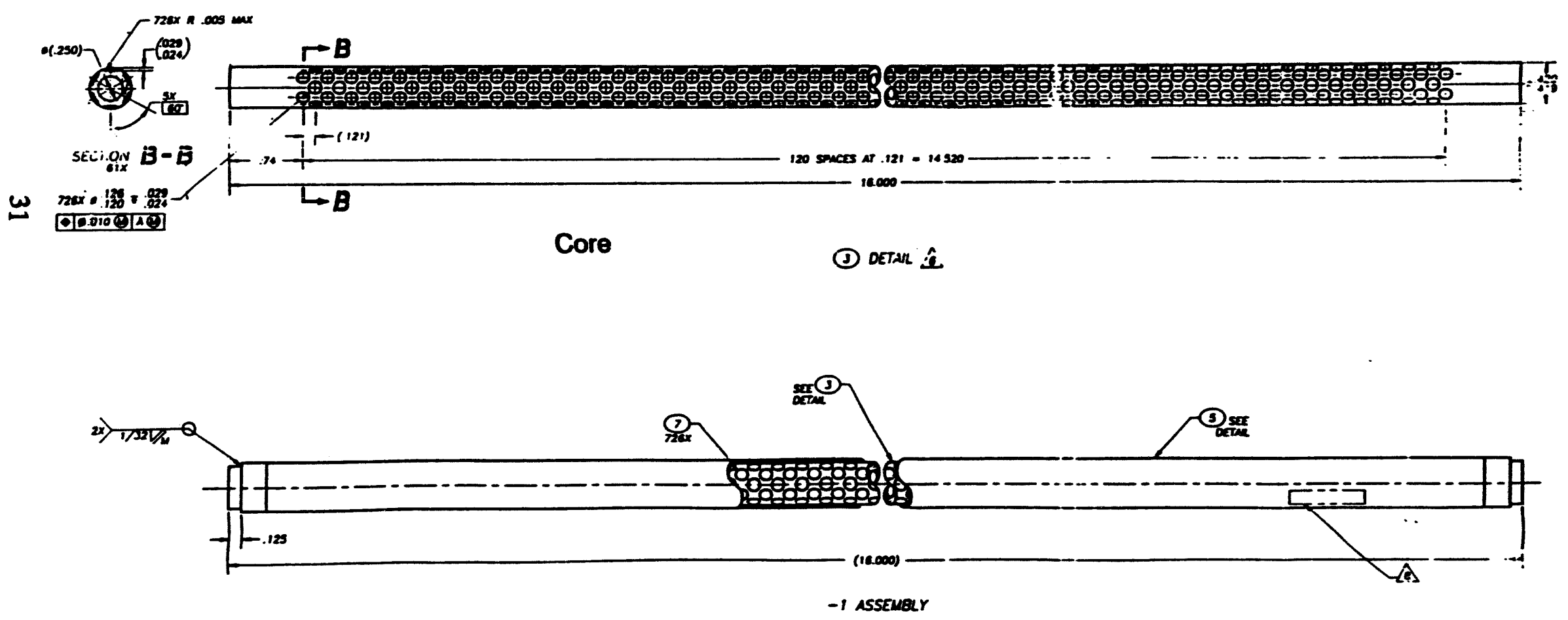

Fig. 4.2. Iridium-target design details. 


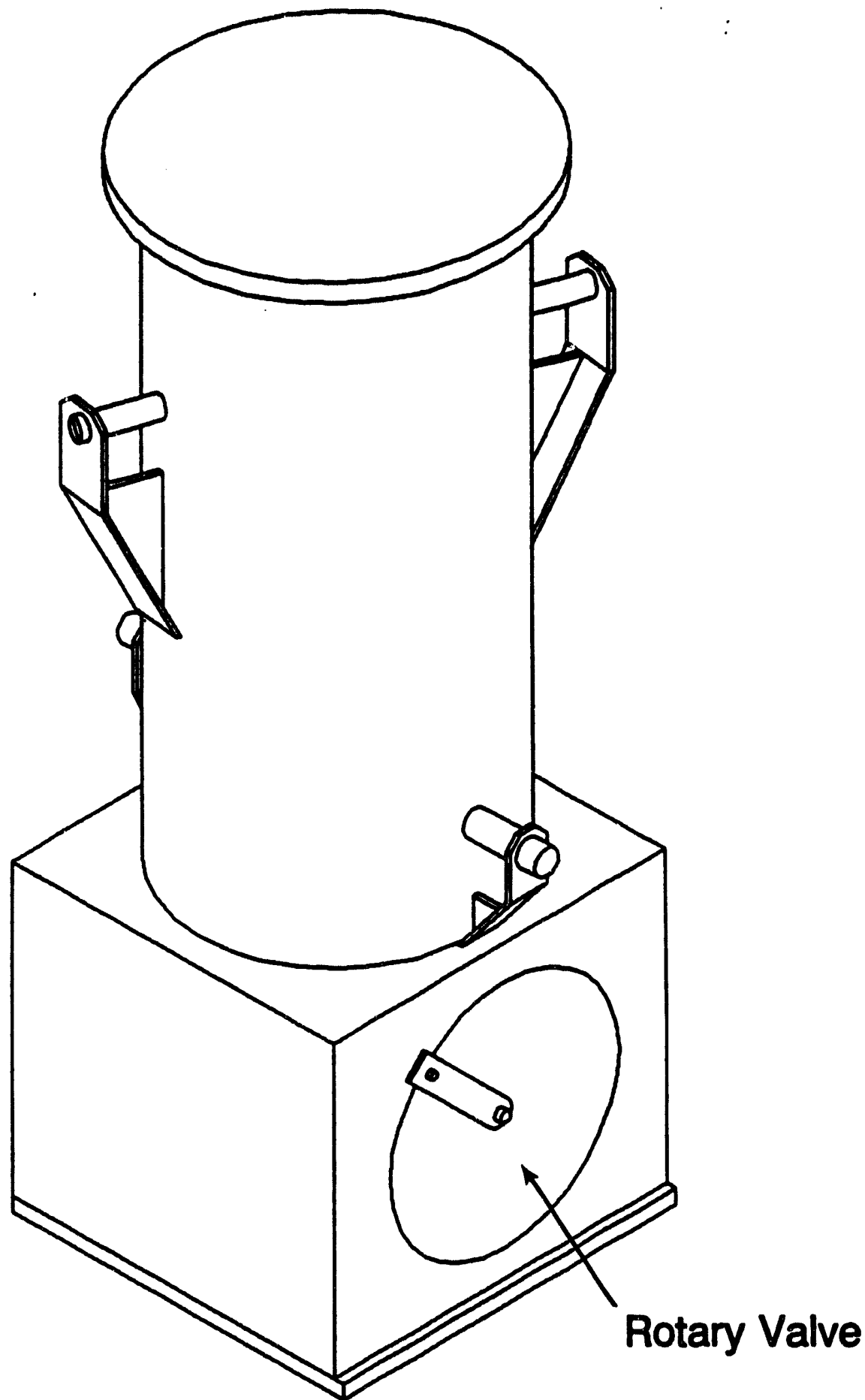

Fig. 4.3. Iridium target-rod shipping cask (HRLEL carrier). 


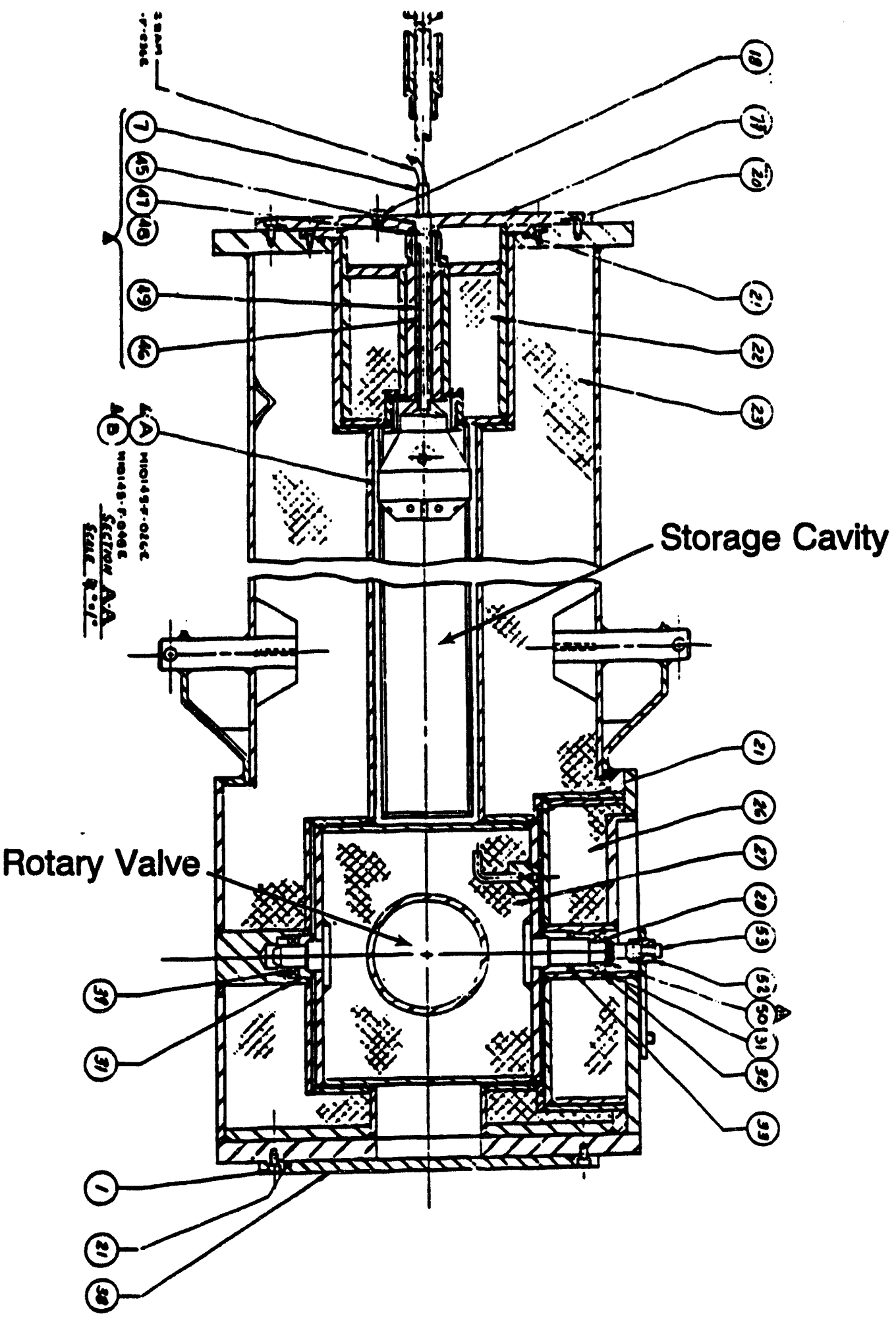
carrier).

Fig. 4.4. Vertical cross section of iridium target-rod shipping cask (HRLEL 

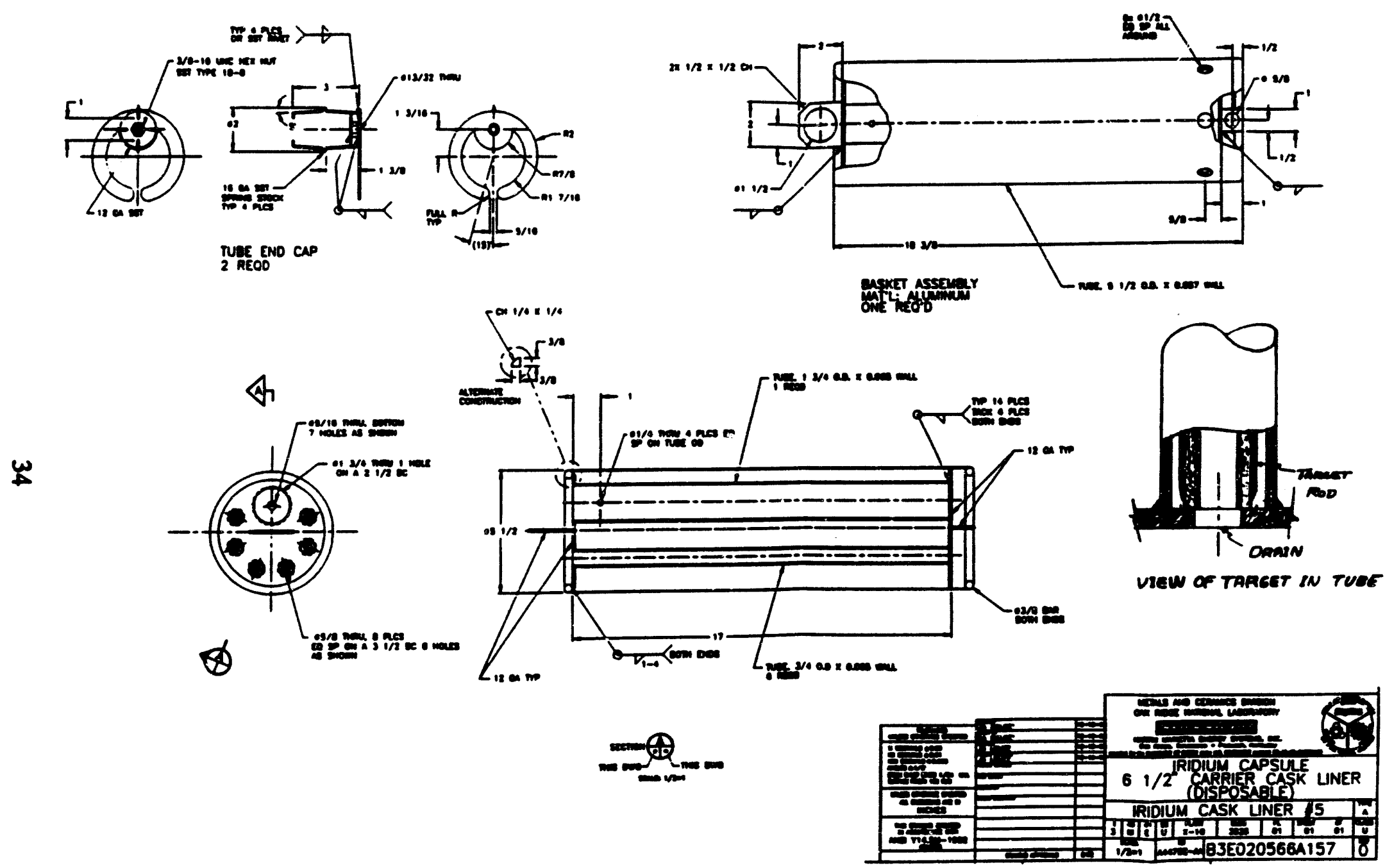

Fig. 4.5. Transfer can for iridium target rods. 


\section{Iridium Target Transfer Sheet}

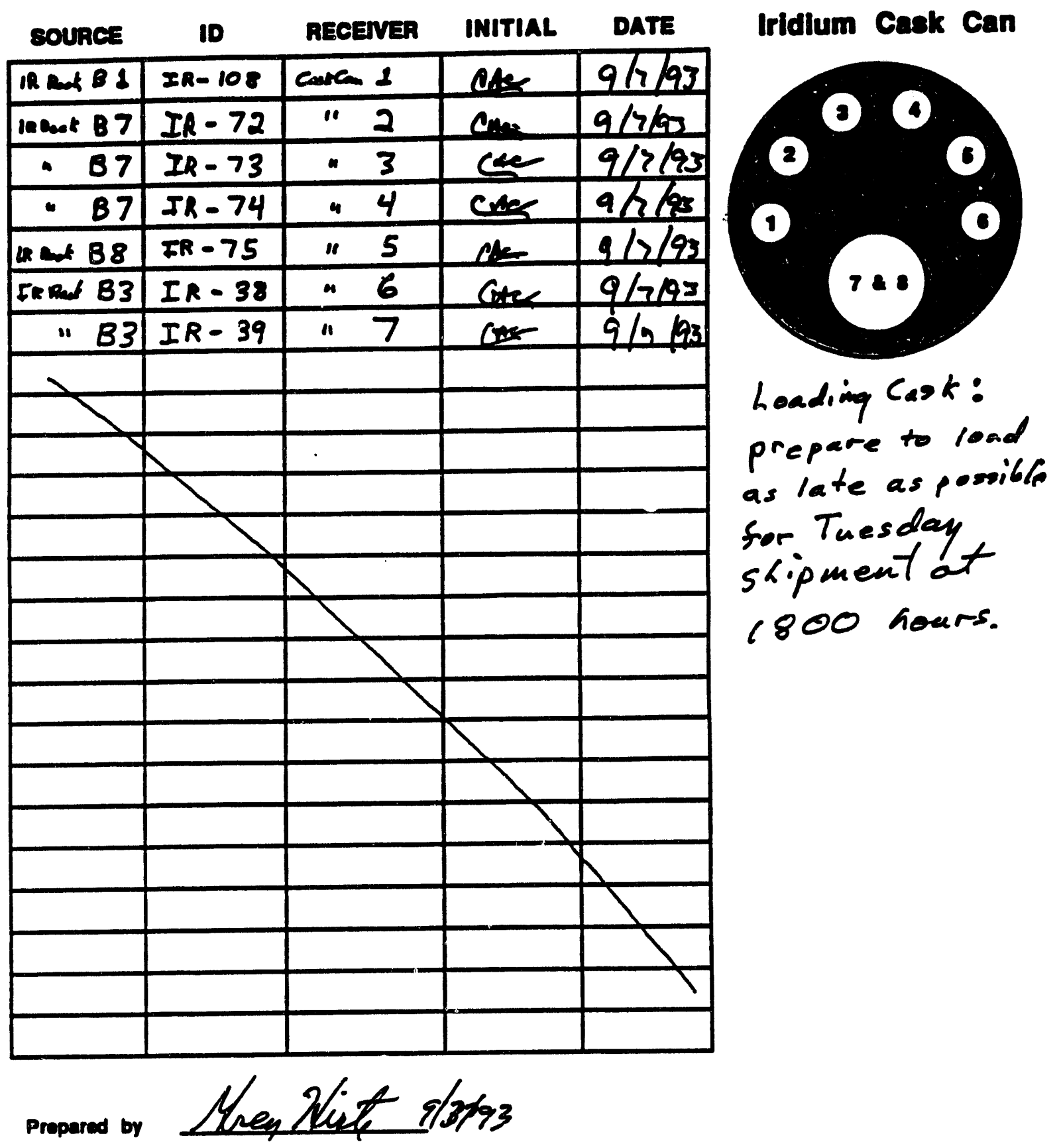

Fig. 4.6. Record of locations of iridium target rods in transfer can. 


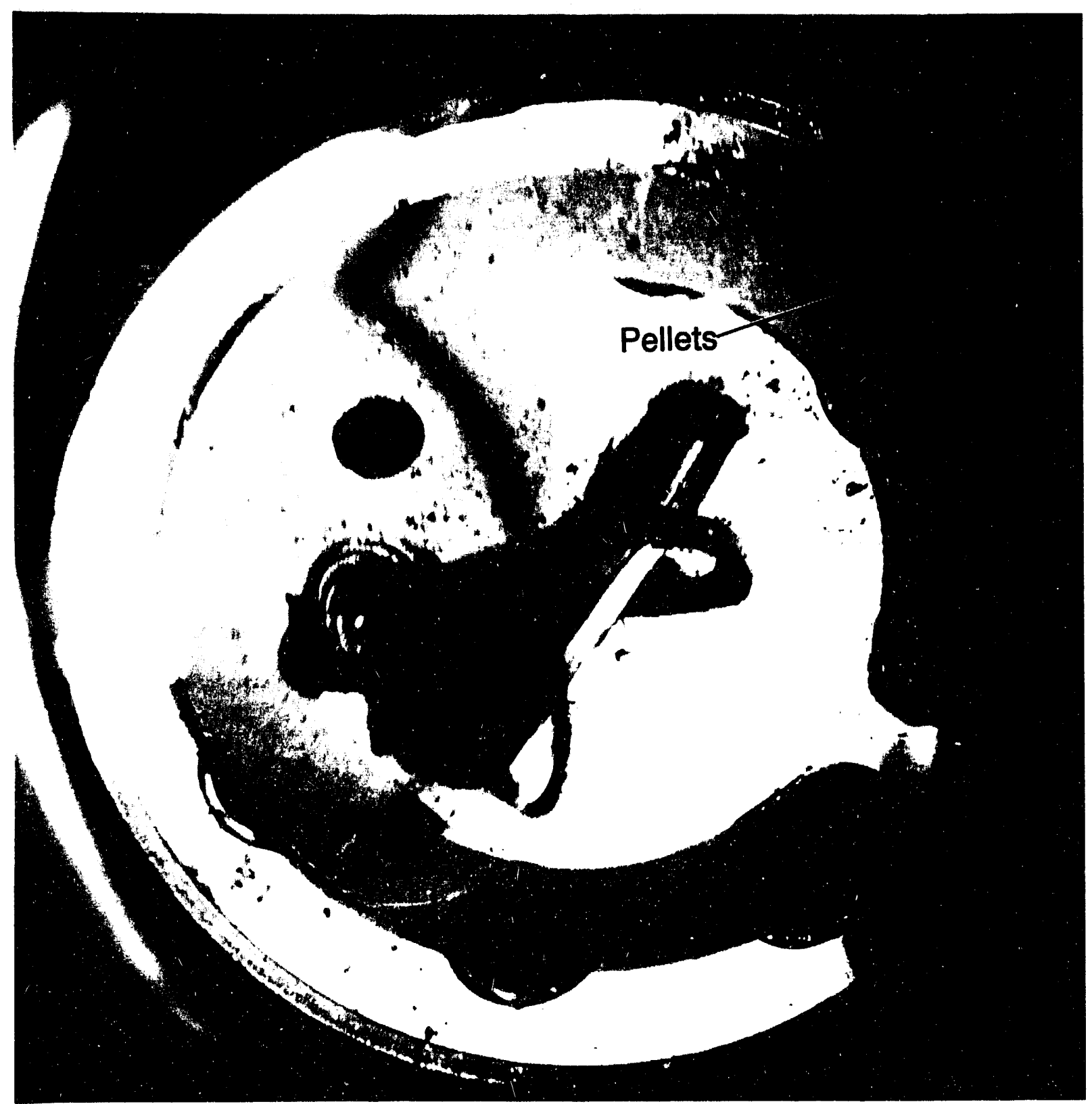

Fig. 4.7. Photo of top of iridium target-rod transfer can showing several iridium pellets and a dark fluffy material. 


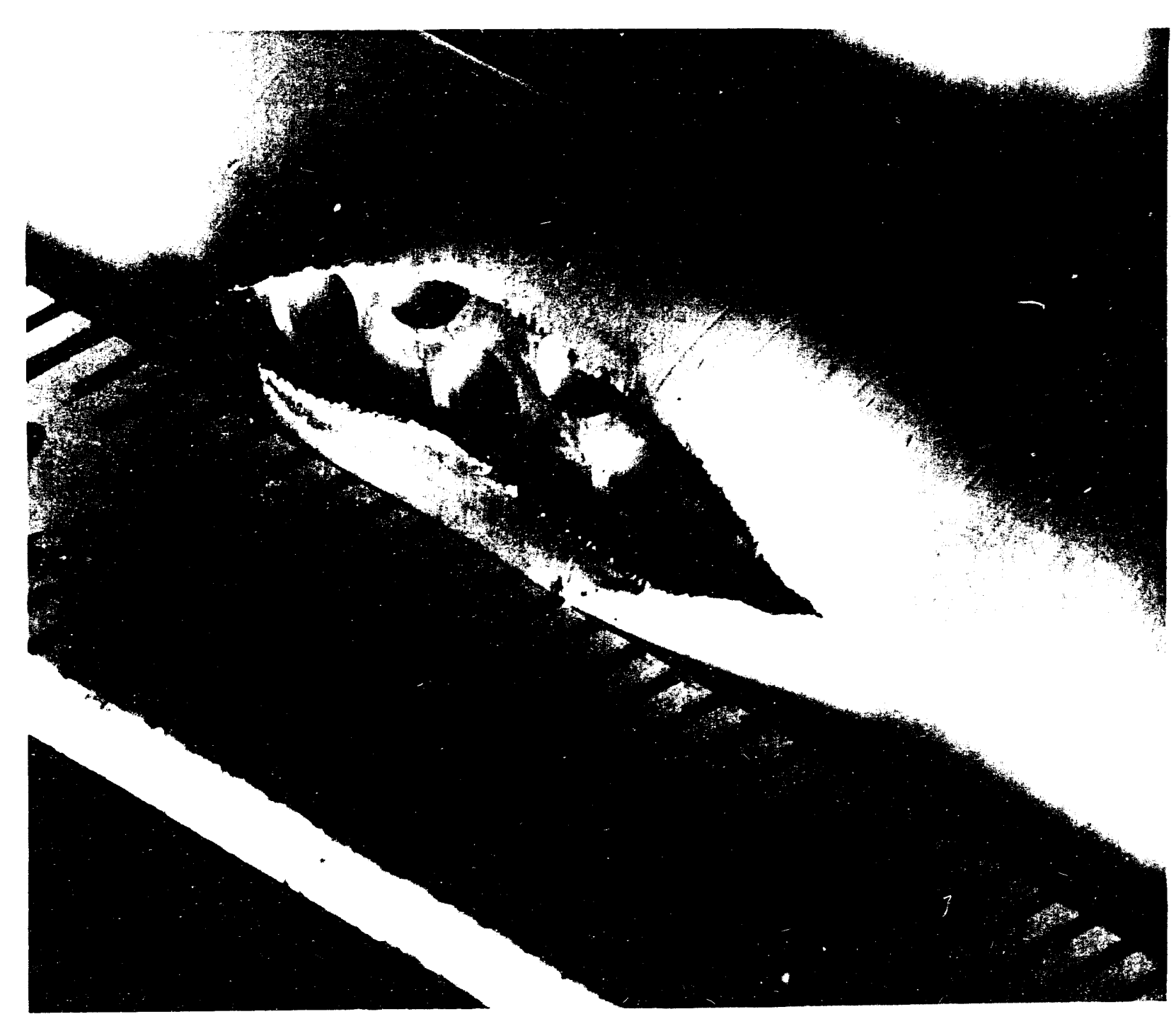

Fig. 4.8. Closeup view of rupture in iridium target rod IR-75, showing vacant iridium-pellet recesses and discoloration of interior surfaces. 


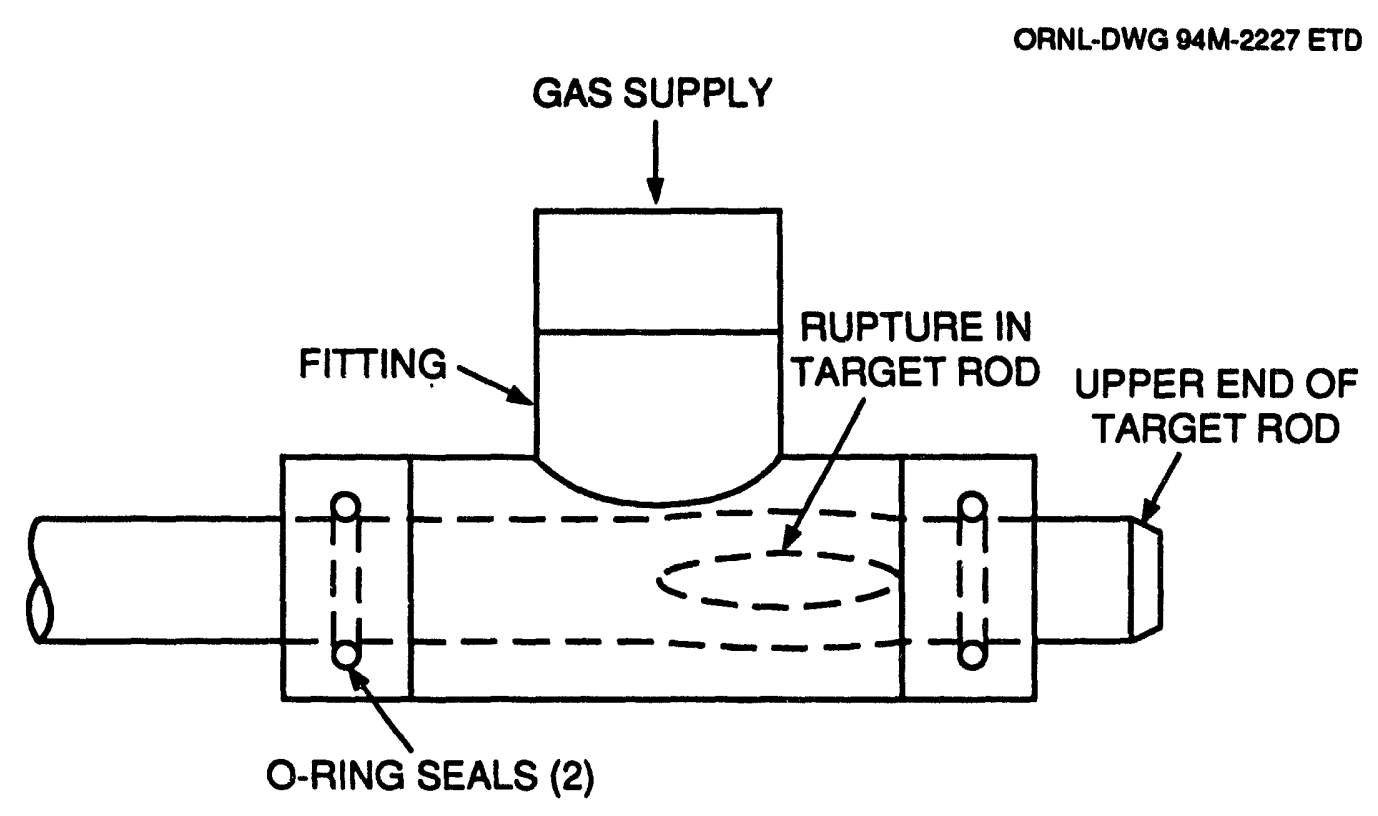

Fig. 4.9. Schematic of assembly for pressurizing void space in ruptured target rod IR-75. 


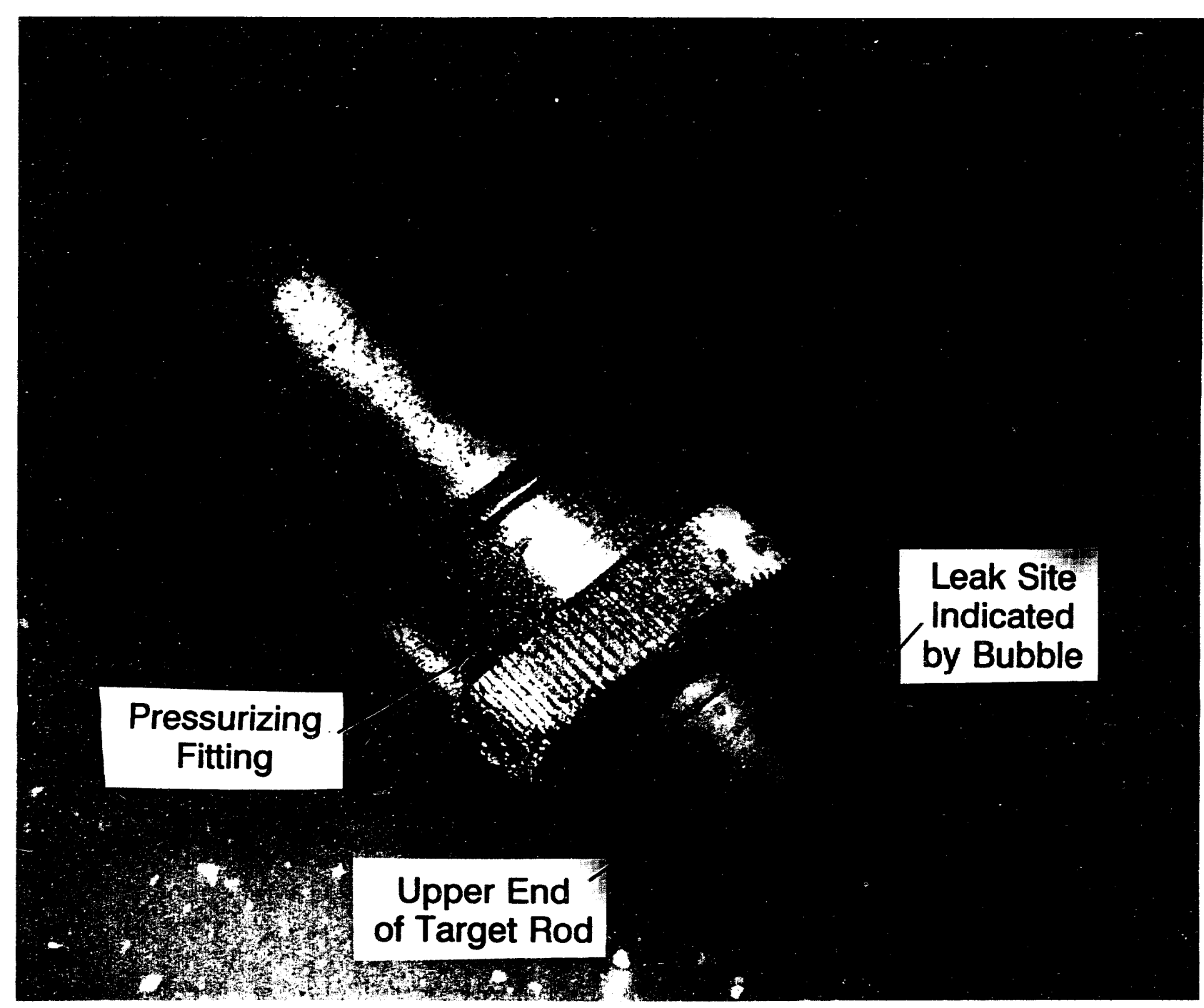

Fig. 4.10. Evidence and location of leak in upper end of iridium target rod IR-75. 


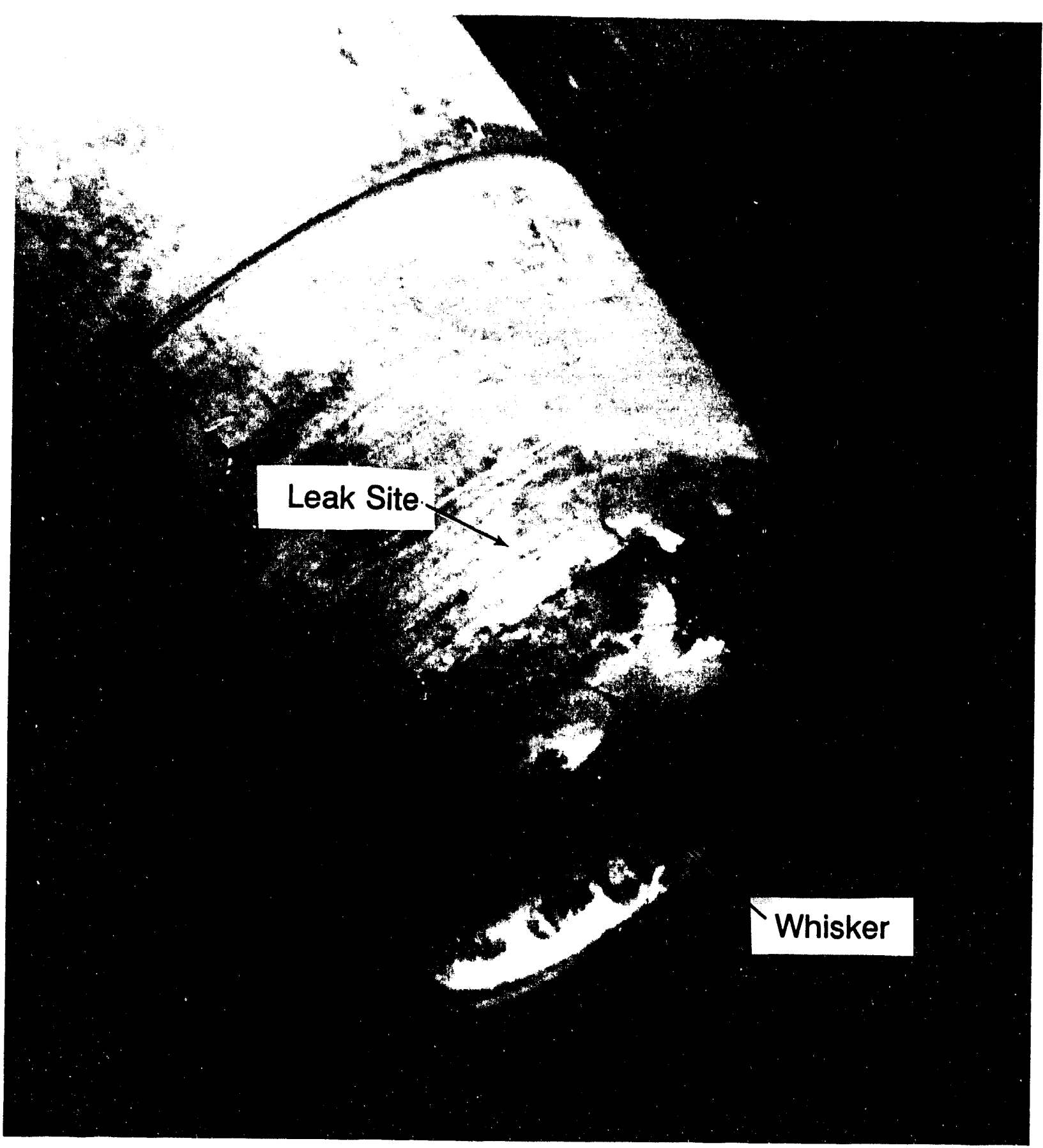

Fig. 4.11. Photo of upper end of iridium target rod IR-75, showing whisker, unusual looking portion of weld, and approximate site of leak. 


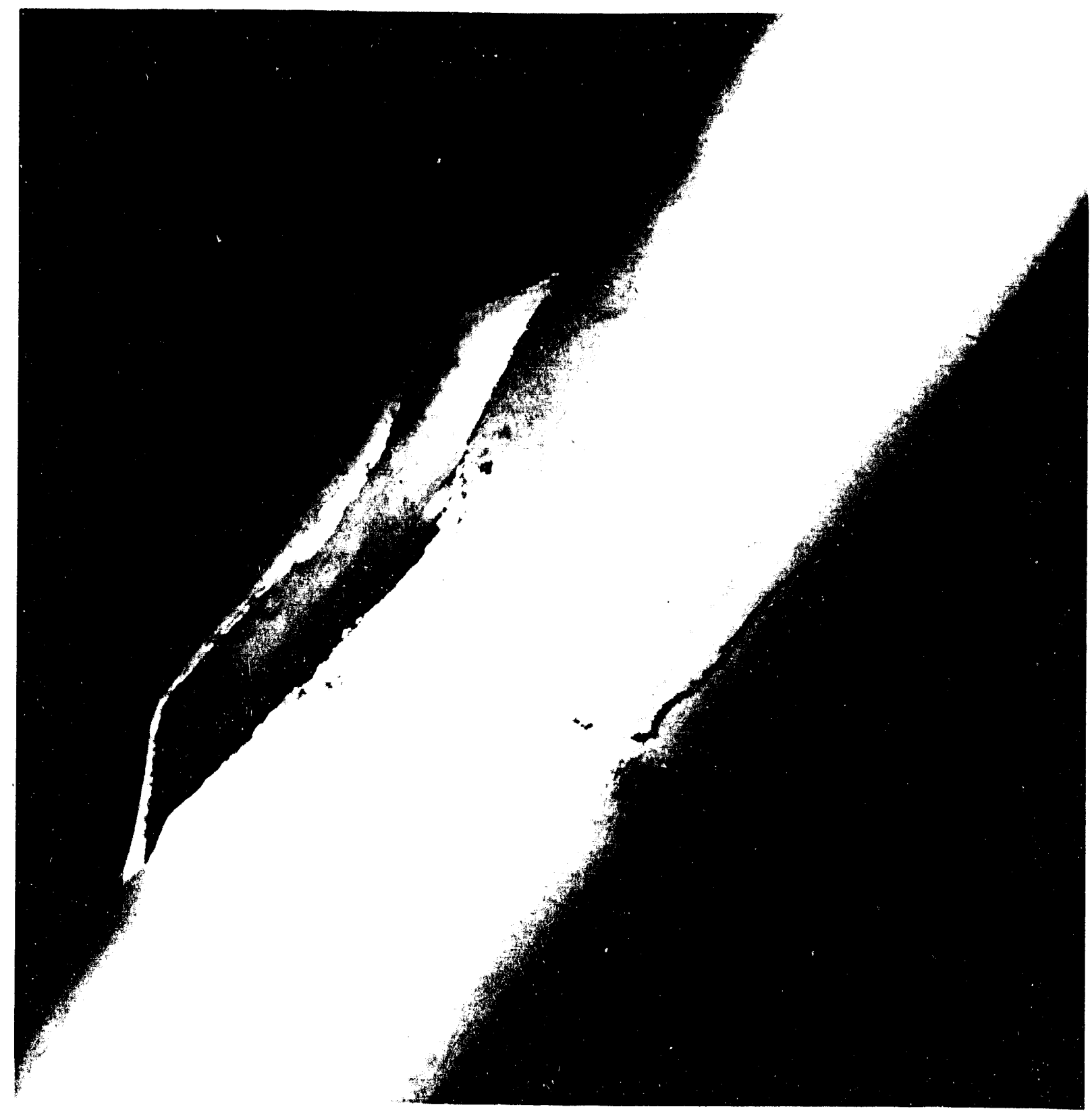

Fig. 4.12. Closeup view of iridium target rod IR-75, showing lack of swelling of the sheath opposite the location of the rupture. 


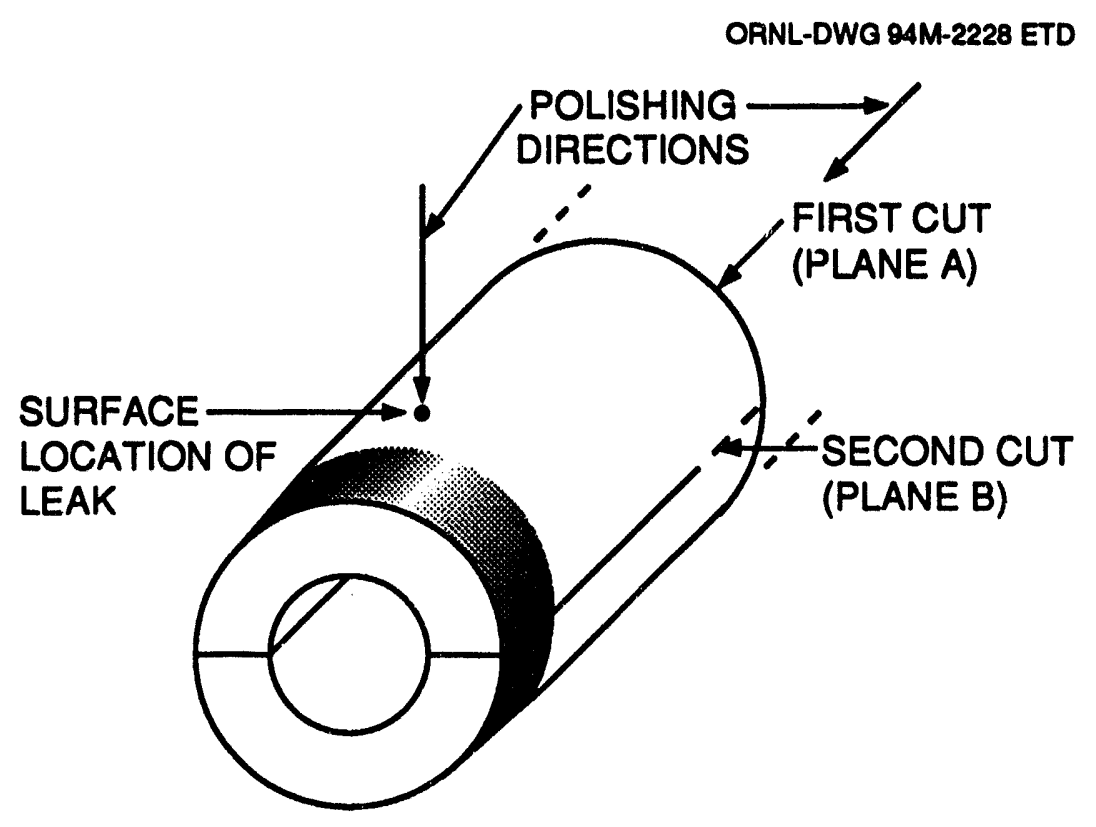

Fig. 4.13. Cutting sequence and polishing directions for upper end of iridium target rod IR-75. 


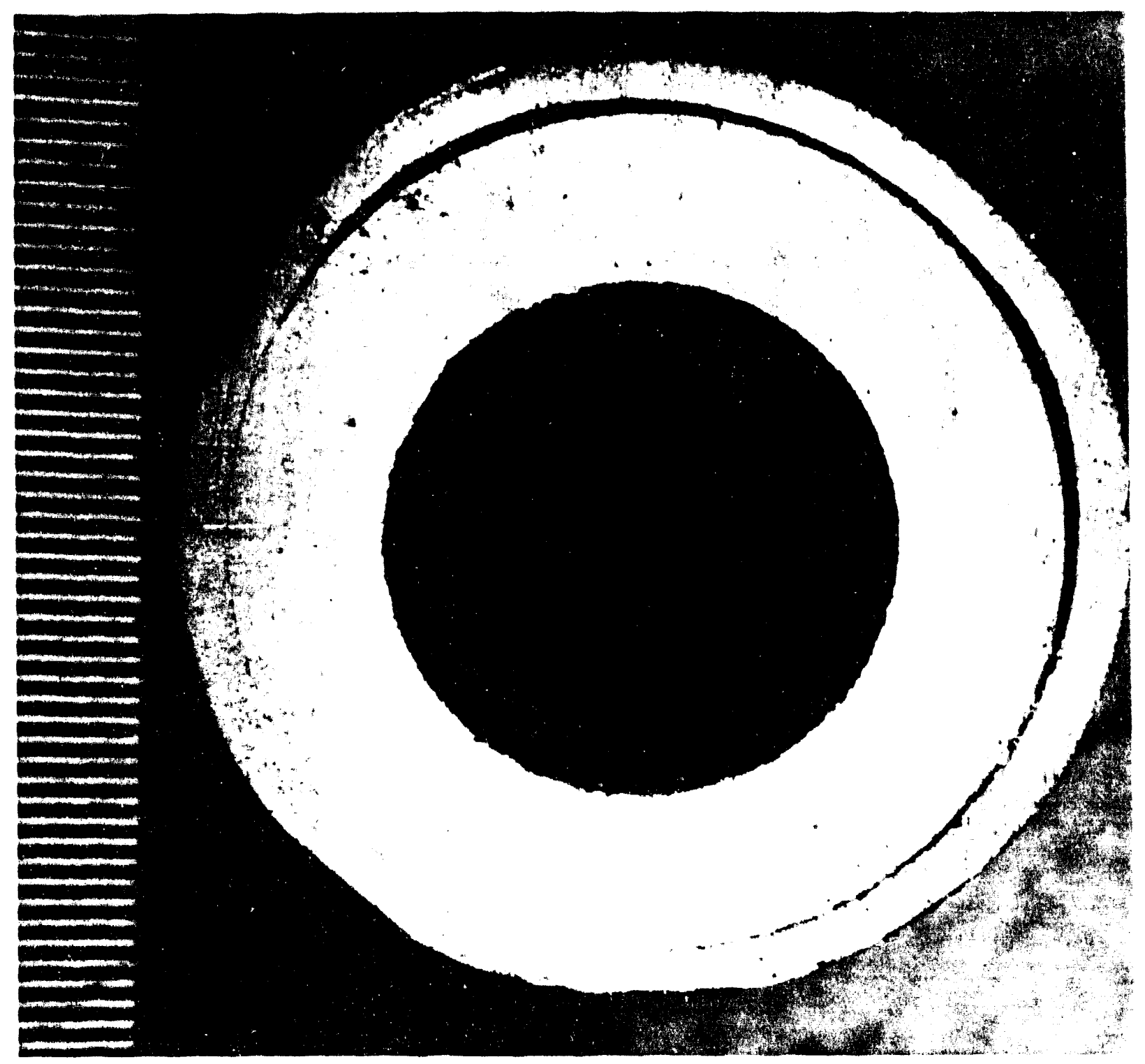

Fig. 4.14. Closeup of cut end of cutoff upper end of iridium target rod IR-75. 


\section{End of}

Target Rod

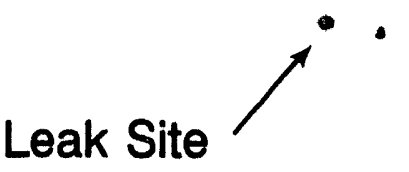

\section{Polished}

Area

Fig. 4.15. Polished outer surface of upper end of iridium target rod IR-75, showing cross section of leakage path close to outer surface (polishing depth $\sim 0.014$ in.). 


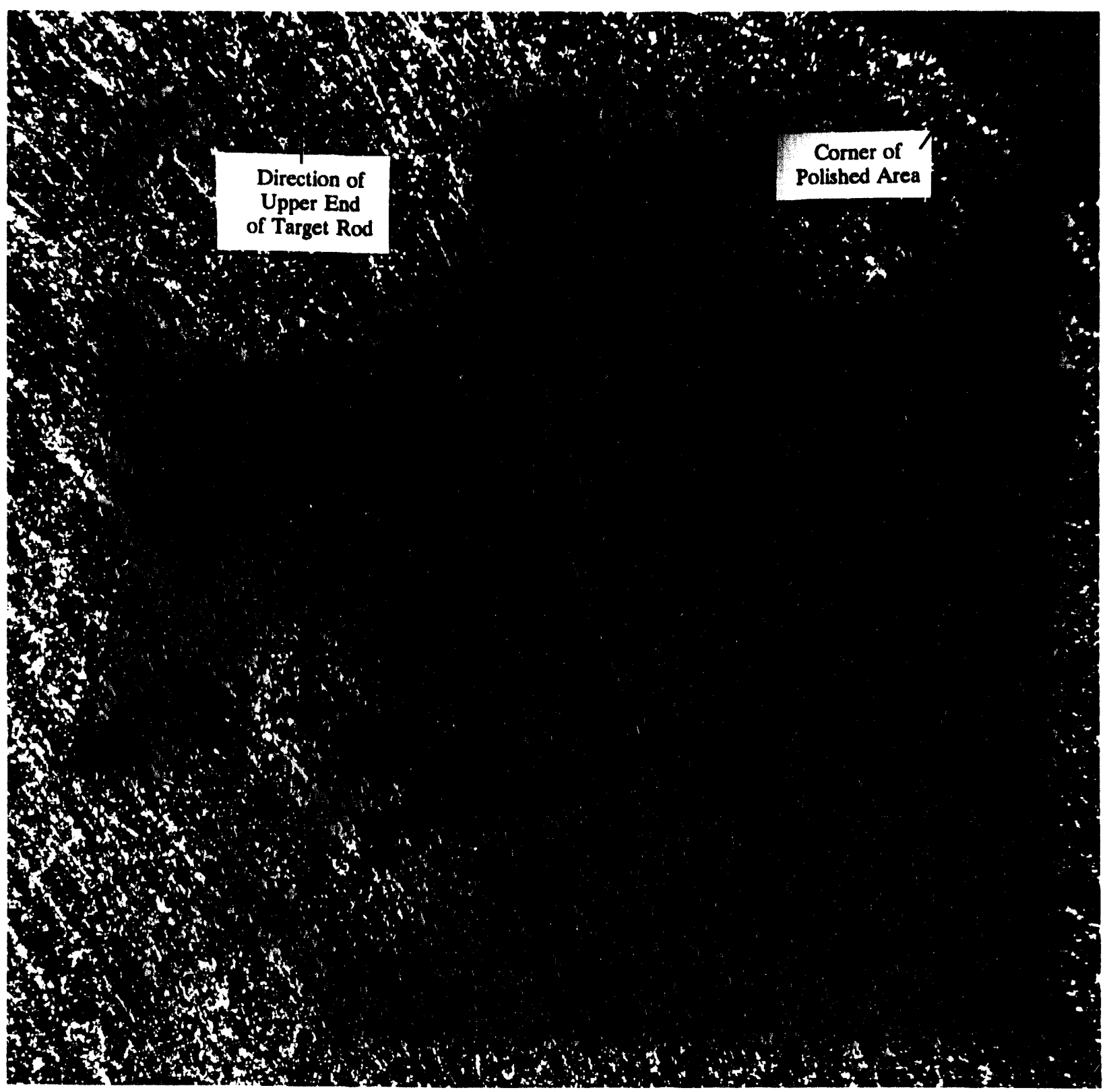

Fig. 4.16. Second step in polishing of outer surface of upper end of iridium target rod IR-75, showing changing pattern of voids (holes) compared to that revealed by first step in polishing (Fig. 15). 


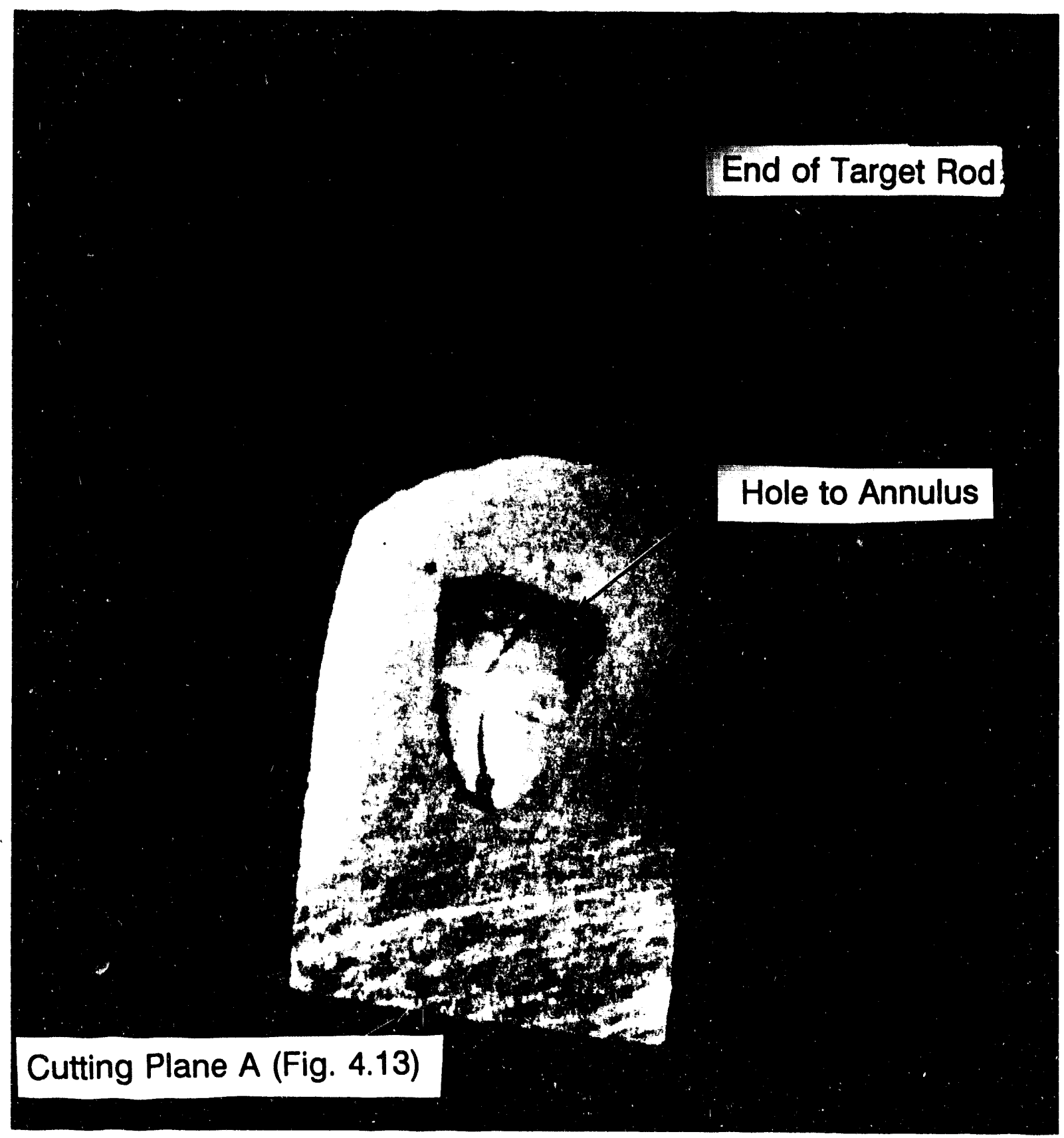

Fig. 4.17. Final step in polishing of outer surface of upper end of iridium target rod IR-75, showing triangular-shaped opening to annulus between sheath and core (polishing depth $\sim 0.023$ in.). 


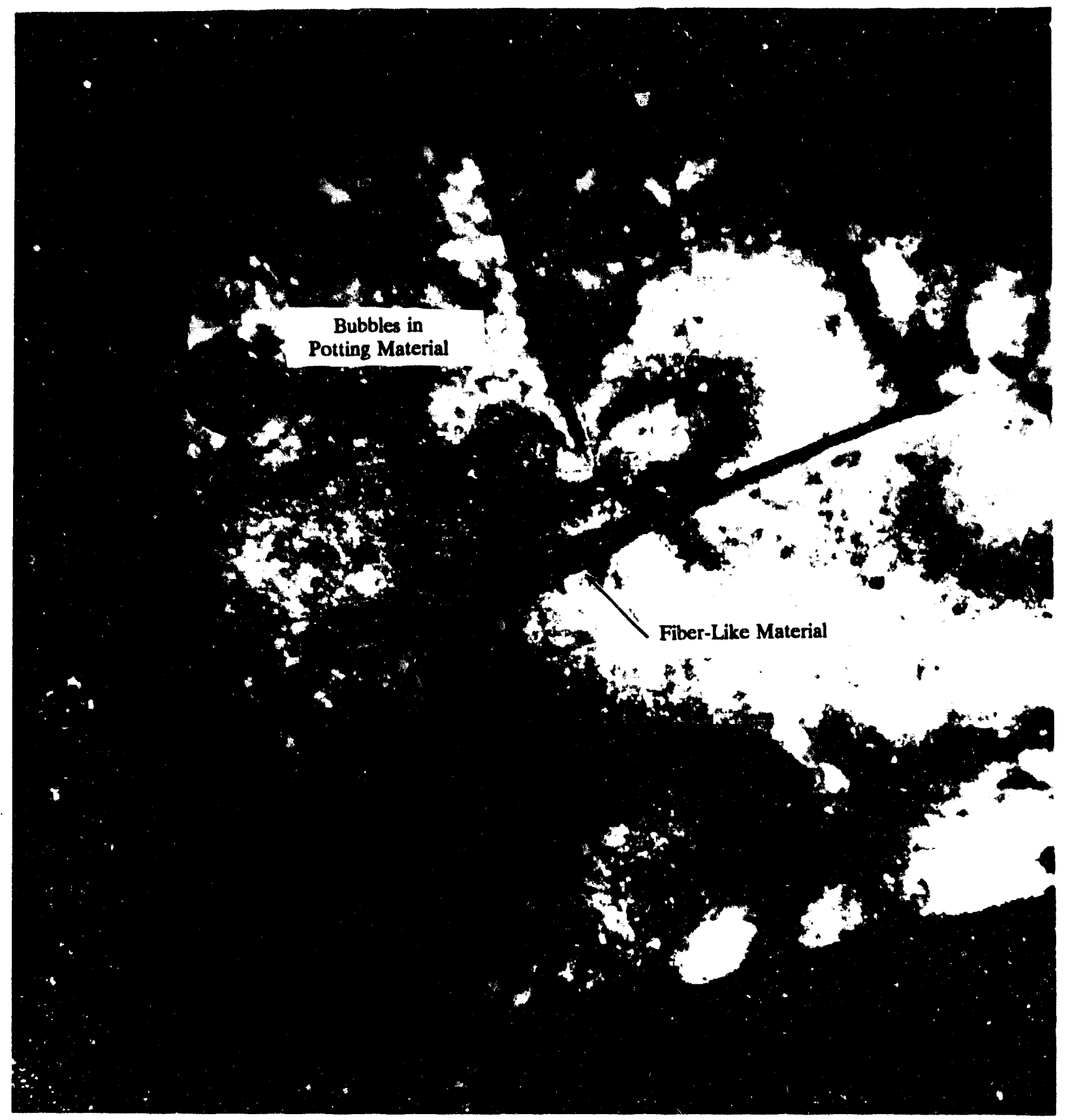

Fig. 4.18. Enlarged view through triangular opening in upper end of iridium target rod IR-75, showing fiber-like foreign material. 


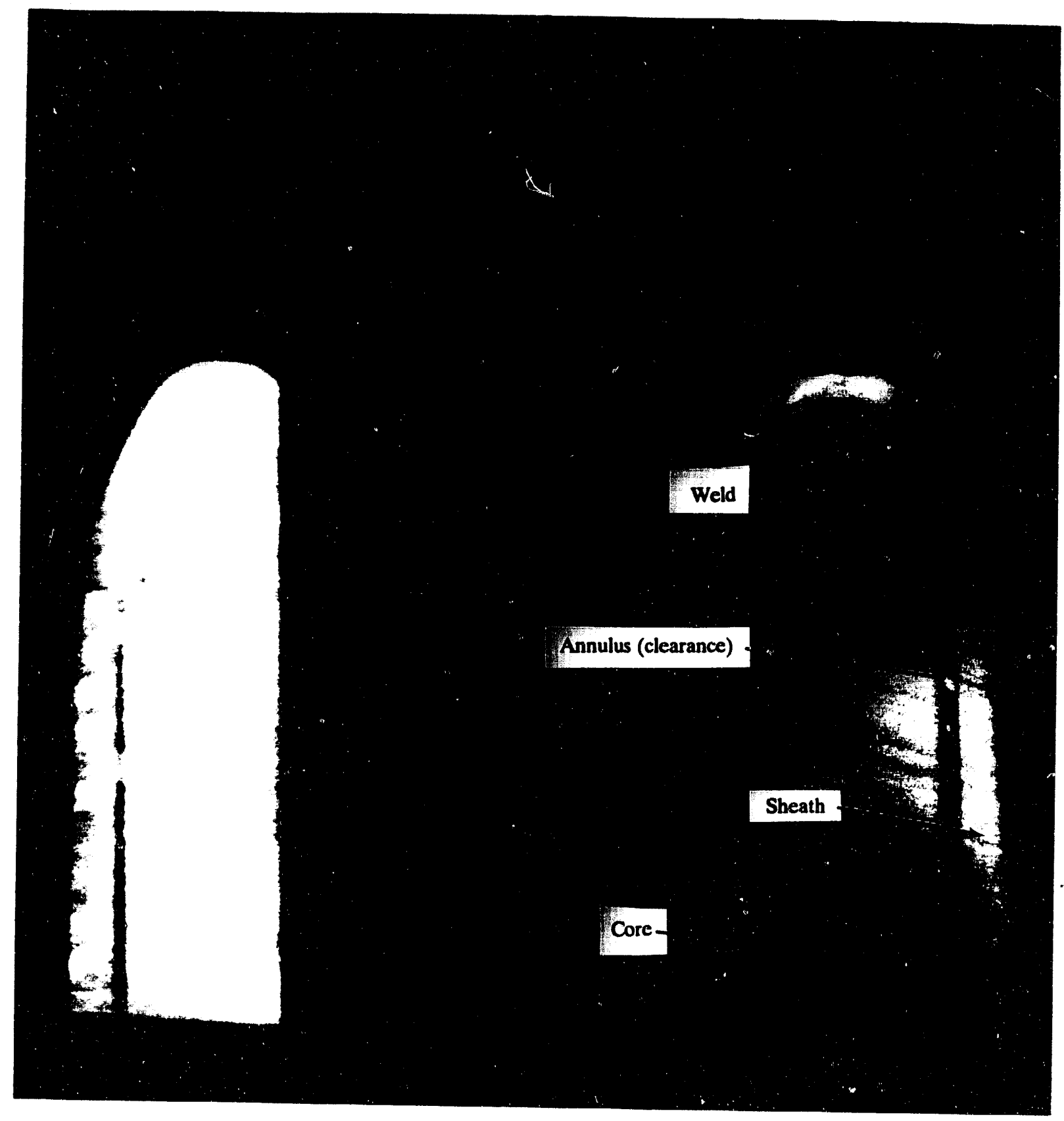

Fig. 4.19. Longitudinal cross section of cut-off upper end of iridium target rod IR-75 ( $90^{\circ}$ from leak site) showing difference in location of end of clearance (annulus) between sheath and core in this particular plane. 


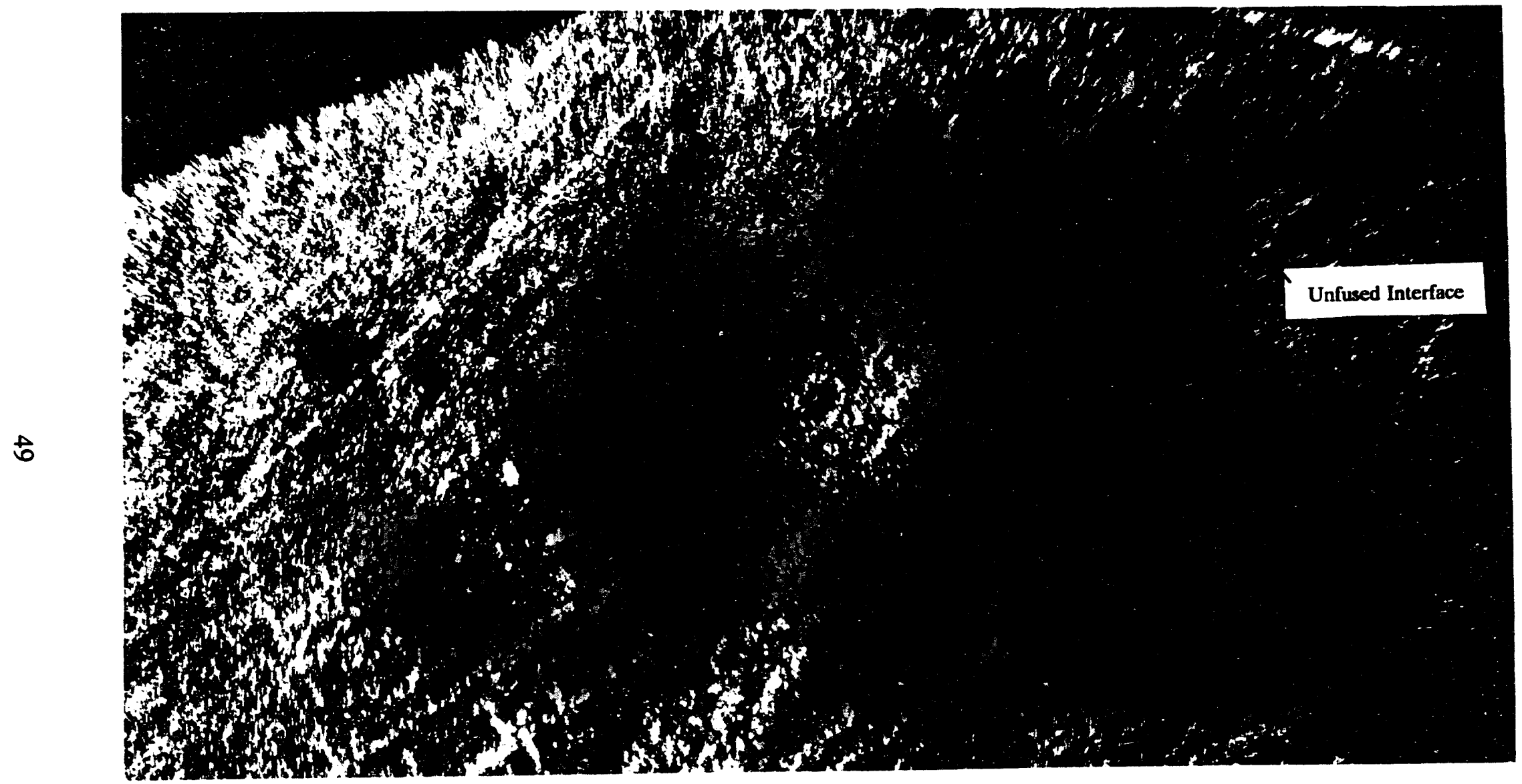

Fig. 4.20. Enlarged view of weld area at end of narrower clearance between target-rod sheath and core (mirror image enlargement of Fig. 19) showing porosity and unfused interface. 


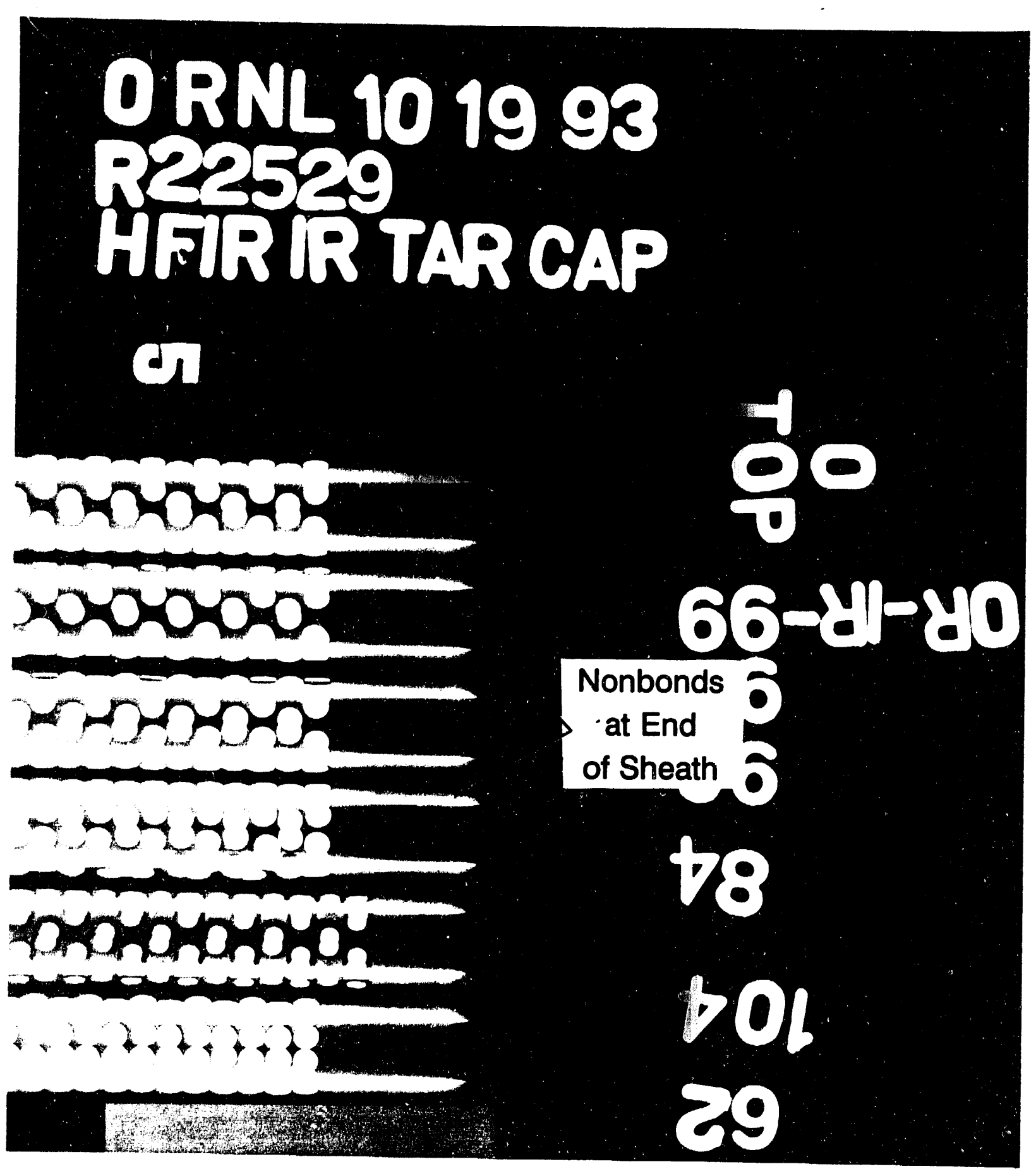

Fig. 4.21. Radiograph of six unirradiated iridium target rods, showing nonbonds (unfused areas) at the ends of two sheaths. 


\section{CONCLUSIONS}

\subsection{FINDINGS}

5.1.1 On September 7, 1993, target rod IR-75 ruptured and released pellets into the interior of the cask. The rupture was caused by radioactive decay heating of water that had been trapped in the target rod. Water entered the target rod through a defect in one of the welds while the target rod was subjected to the reactor operating pressure of about 500 psi during three reactor fuel cycles.

5.1.2 On September 7, 1993, one or more of the pellets, or pieces of pellets, that were released into the cask made their way through passageways in the cask to the floor of the HFIR bay. The cask configuration used to hold the target rods during transport could have included a bottom flange or a sealed can that would have contained the "pellets" inside the cask during transport. Neither was a requirement, and neither was used.

5.1.3 All of the INEL weld procedure requirements were not followed in the welding process.

5.1.4 The purity of the shielding gas used during welding at INEL could not be determined.

5.1.5 The actual flow rate of the shielding gas used during welding at INEL could not be determined.

5.1.6 The material used to fabricate the targets at INEL were not fully controlled.

5.1.7 INEL target inspection methods did not include radiography.

5.1.8 The receipt, storage, and transfer of the target rods at ORNL was not documented and there was no requirement to document them.

5.1.9 Target material samples and fabrication work packages were not sent with the target rod.

5.1.10 ORNL did not perform required chemical analysis and hardness testing of the target rod until after the event.

5.1.11 There were no procedures written to specifically test the INEL iridium target rods.

5.1.12 The target rod was accepted at ORNL based upon the helium leak test results only. There were not requirements to review other test results and no procedure for doing so. 
5.1.13 The exact storage of the target rod at the HFIR site could not be determined.

5.1.14 All requirements of the DOE Hoisting and Rigging Manual for pre-engineered production lifts were not met.

5.1.15 During the event, two people could not be immediately accounted for.

5.1.16 Results of surveys of personnel for contamination after evacuation were not entered into the HP log.

5.1.17 "Informal" communications between HFIR and DOE personnel on-site resulted in conflicting information being supplied to a variety of DOE headquarters personnel.

5.1.18 Operating procedures for handling the target rods and tri-holders and for positioning them in HFIR did not specifically address the target rods and tri-holders being used.

5.1.19 Narrative logs at the HFIR site did not contain sufficient information to totally reconstruct the event.

5.1.20 Documents defining requirements for the program were not always signed in the indicated places prior to use.

5.1.21 One individual entered a posted radiation area without the required direct-reading dosimetry.

5.1.22 Not all iridium pellets have been accounted for.

5.1.23 The HFIR emergency plan was followed and proved to be adequate to address the scope and nature of the event. Actions by HFIR site personnel were timely and applicable to the circumstances. The radiation doses received during the event and cleanup of the event were very low. The only property damaged was the target rod, but iridium pellets still remain in the cask. No environmental impact resulted from this event.

5.1.24 An ALARA plan was established and implemented for the cask-recovery operations to ensure minimum exposure to personnel. A transportation plan, including a safety assessment of this type of event, had been written, approved, and implemented. A mockup was built and used for training purposes to prepare to move the cask from the HFIR site to the hot cells. These plans addressed the hazards and contributed to the success of the recovery operations, including very low exposure to personnel who worked with the highly radioactive materials during the cleanup and recovery activities. 
5.2.1 Less than adequate welding procedures, practices, techniques, material controls, or inspection methods, or some combination of these, could have led to weld defects such as those that affected target rod IR-75.

5.2.2 Less than adequate secondary containment in the cask allowed iridium "pellets" to escape.

\subsection{JUDGEMENT OF NEEDS}

5.3.1 A secondary container is needed to ensure that iridium pellets that are released from a failed target rod are contained in the cask.

5.3.2 The target fabrication process needs to be improved to ensure the following:

- Procedural requirements are followed during target fabrication.

- The purity of the shielding gas is appropriate during welding of the targets and is documented.

- Shielding gas flow is appropriate during welding of the targets and is documented.

5.3.3 Quality control of target material needs to be improved.

5.3.4 The INEL method of target inspection needs to be improved.

5.3.5 Target material samples and fabrication work packages need to be supplied to ORNL when targets are delivered.

5.3.6 ORNL procedures need to be revised or developed to specifically address the following:

- receipt, storage, handling, and transfer of target rods

- testing of the target rods prior to introduction into HFIR

5.3.7 All future cask hoisting and rigging operations need to comply with the requirements of the DOE Hoisting and Rigging Manual.

5.3.8 Mechanism for ensuring personnel accountability during an emergency needs to be improved.

5.3.9 HP log keeping practices need improvement. 
5.3.10 HFIR narrative log keeping practices need to be improved.

5.3.11 Requirements for communications between local personnel and DOE headquarters need to be better defined.

5.3.12 All personnel need to wear direct reading dosimetry where required.

5.3.13 All iridium pellets need to be accounted for, processed, or disposed of. 


\section{SIGNATURES OF BOARD MEMBERS}

This investigation was conducted and this document prepared by the following investigation board members.

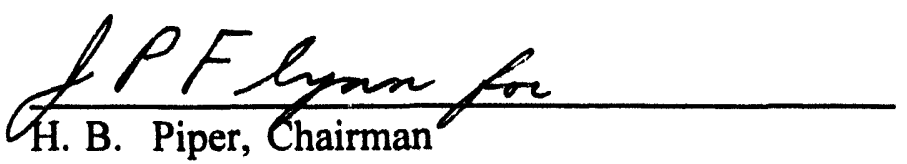

Energy Systems

Evaluations Manager

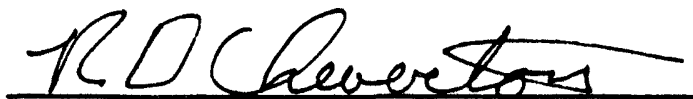

R. D. Cheverton

Energy Systems, ORNL

Section Manager, Engineering Technology Division

S. A. Hamley *

Energy Systems, ORNE

Conduct of Operations Officer, Office of Radiation Protection

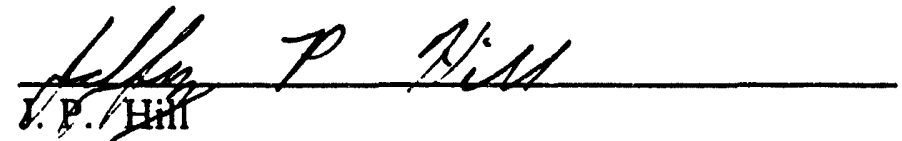

Energy Systems, ORNL

Safety Representative, Atomic Trades and Labor Council

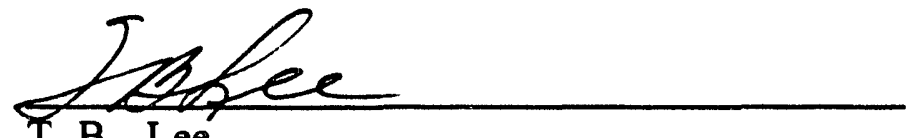

T. B. Lee

United Energy Services Corporation

Consultant

$\sum_{\text {J. A. West * Weat }}$

Energy Systems, Y-12 Plant

Assessments Manager, Quality Department

*These Board members are certified Accident/Incident Investigators. 
APPENDIX A

MEMORANDA OF APPOINTMENT

56 


\section{Department of Energy}

Oak Ridge Operations

P.O. Box 2001

Oak Ridge. Tennesese 37831-

September 9, 1993

Mr. Henry B. Piper

Mart in Marietta Energy Systems, Inc.

Evaluations Program Manager

701 Scarboro Road

Oak Ridge, Tennessee 37831-8241

Dear Mr. Piper:

INVESTIGATION OF IRIOIUH CONTAMINATION IMCIDENT AT THE HIGH FLUX ISOTOPE REACTOR (HFIR), OAK RIDEE MATIOMAL LABORATORY

You are hereby appointed Chairman of the Investigation Board to investigate the subject incident which occurred on September 7, 1993. Your assignment is to determine the cause of this incident and provide recommendations for corrective action.

You are to perform a Type B Investigation of this incident and to prepare an investigation report. The report shall conform to the requirements detailed in DOE Order 5484.1. The scope of the investigation is to include all of the factors which contributed to the cause and extent of the incident. Special emphasis should be placed on the process for acceptance, control and handling of the targets (from initial receipt through shipping) and as low as

reasonably achievable (ALARA) preplanning, mock-up training, and other related activities performed before major operations were initiated.

If additional resources are required to assist you in completing this task, please let me know and they will be provided. You and members of the Board are relieved of your other duties until this assignment is completed. The Board shall brief representatives of the Oak Ridge Operations Office on a weekly basis as to the status of the investigation. The point of contact for ORO will be Bob Edlund, Advanced Neutron Source Project.

The following employees have been appointed to serve as members of the Board:

Richard D. Cheverton, Section Head, ORNL Engineering Technology Division Tormy Lee, Senior Consultant, United Energy Services Corporation Jeff Hill, ORNL ATLC Environment, Safety and Health Representative Steve Hamiey, ORNL Conduct of Operations Officer, Office of Radiation Protection

Janice West, Assessments Manager, Y-12 Quality Organization, Trained Investigator

Enclosed is a draft copy of Oak Ridge Implementation Guidance (ORIG)

5484.1.2A. which outlines responsibilities of the Investigation Board and

covers the accident investigation process. Also included as Enclosure 2 is a 
copy of a DOE Headquarters booklet entitled, "Practical Guidance for Accident Investigation and Reporting," dated May 1993.

A copy of the draft investigation report should be submitted to me by October 25, 1993.

\section{Sincerely,}

SE-331:Mullins

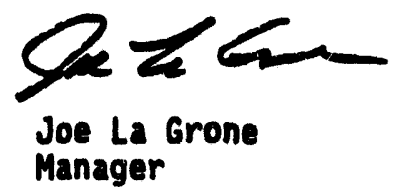

Enclosures:

1. Draft ORIG 5484.1.2A

2. May 1993 Booklet

cc $w / 0$ enclosures:

R. L. Egli, ER-10

H. W. Hibbitts, SE-30

J. T. Alexander, $M-4$

J. D. Rothrock, SE-33

W. F. Manning, ER-12

G. G. Fee, MMESS

M. A. COX, MAES

Fred Mynatt, MMES

Jeff Bostock, $Y-12$, MMES

Trivelpiece, ORNL, MMES

Bob Edlund, ANS 


\section{Department of Energy}

Oak Ridge Operations

P.O. Box 2001

Oak Ridge. Tenneasee 37831-

September 9, 1993

Mr. Gordon G. Fee, President

Martin Marietta Energy Systems, Inc.

Post Office Box 2009

Oak Ridge, Tennessee 37831-8002

Mr. Fee:

INVESTIGATION OF IRIOIUN CONTAMINATION INCIDENT AT THE HIEH FLUX ISOTOPE REACTOR (HFIR), OAK RIDGE MATIONAL LABORATORY

As a result of the subject incident on September $7,1993,1$ an requesting that a Type B Investigation be performed. The following Martin Marictta Energy Systems, Inc. (MMES), emplujees have been appointed to the board:

Henry Piper, MMES Ejaluations Program Manager, Chairman

Rich:=ru D. Chevertc?, Sec:ion Head, ORNL Engineering Technoiogy Division

Touny Lee, Senior Consuitant, United Energy Services Corporation

Jeff Hill, ORNL ATLC Environment, Safety and Heilth Representative

Steve Hamiey, OPNL Corduct of Operations Cfficer, Office oi Radiation Protection

Janice West, Assessmerics Manager, Y-12 Quality Organization, irained Investigator

The investigation and preparacicr of the resulting report will cunforn to DCE Order 5484.1 requirements. The scese of the investigation is to inciude all of the factors which contribuzed significantly to the cause and effect of the incident. Special emphasis will be placed on the process for acceptance, control and handling of the targets (from initial receipt through shipjing) and as low as reasoriably achievable ALARÁ) preplenning, mock-up training, and oth?r related activities periormed b: fore major operations were initiated. The Board will brief the Oak Ridẹe (IF rations Office on a weekly bas is as to the statis of the investigation. The ORO point of contact is Bob Edlund, Advanced lieutron Source Project. 
Mr. Gordon G. Fee $\quad-2$ -

A copy of the draft investigation report should be submitted to me by October 25, 1993.

Sincerely,

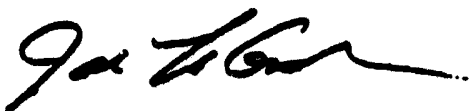

SE-331:Mullins

Joe La Grone

Manager

Cc:

R. L. Egli, ER-10

H. W. Hibbitts, SE-30

J. T. Alexander, $M-4$

J. D. Rothrock, SE-33

A. W. Trivelpiece, MMES

Fred Mynatt, MMES

M. A. COX, MMES

Bob Edlund, ANS 


\section{APPENDIX B}

\section{EVENTS AND CAUSAL FACTORS}


Iridium Spill Events Causal Factors Chart
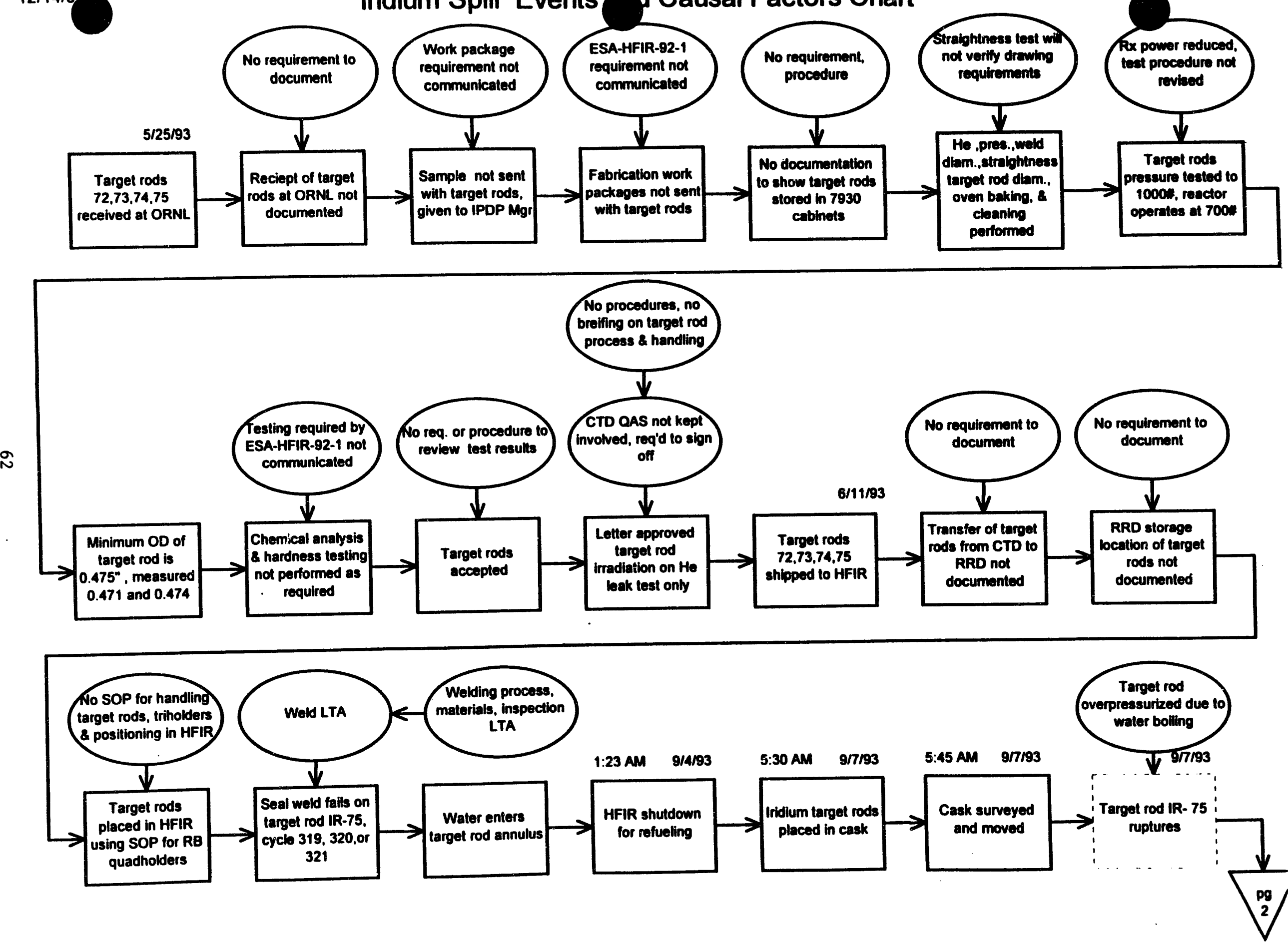


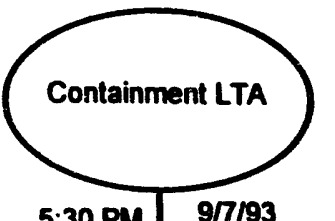

977/93

5:25 PM 9/7/93

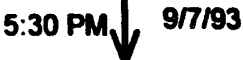

5:30 PM 9/7/93

5:30 PM 9/7/93

5:31 PM 9/7/93

5:32 PM

97/93 HP performs
prelift radiation

Riggers begin HRLEL cask lift,

Iridium released

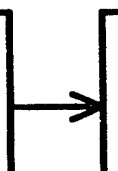
Radiation
monitors in bay
alarm $\geqslant$ Porsonnel begin Ops Manager activates RRD crnorgency survey
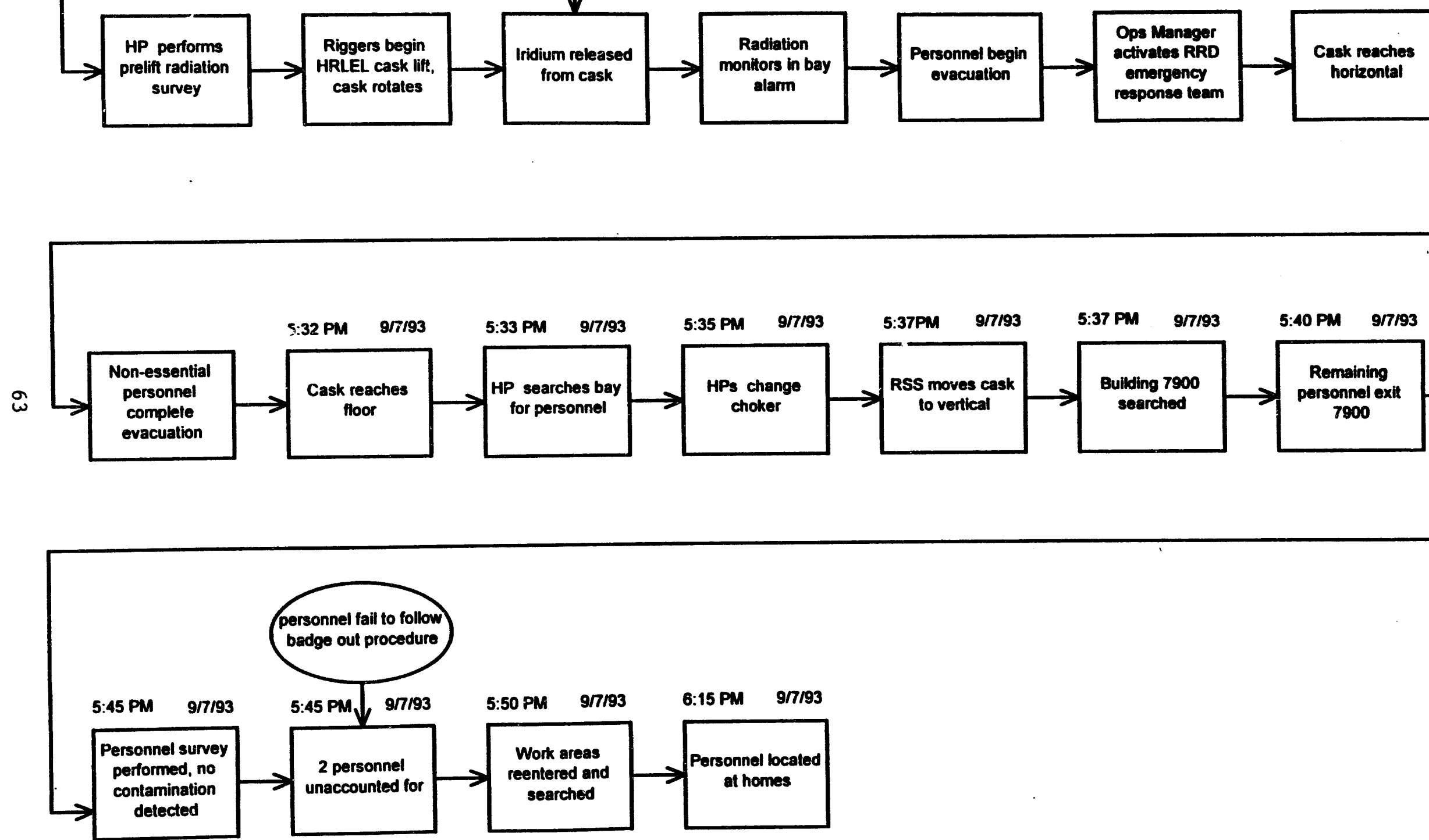
APPENDIX C

ORNL ORGANIZATION CHART

64 
0
$\frac{5}{2}$
$\frac{5}{0}$
$\frac{1}{2}$
$\frac{1}{8}$
0
$\frac{0}{0}$
$\frac{0}{0}$
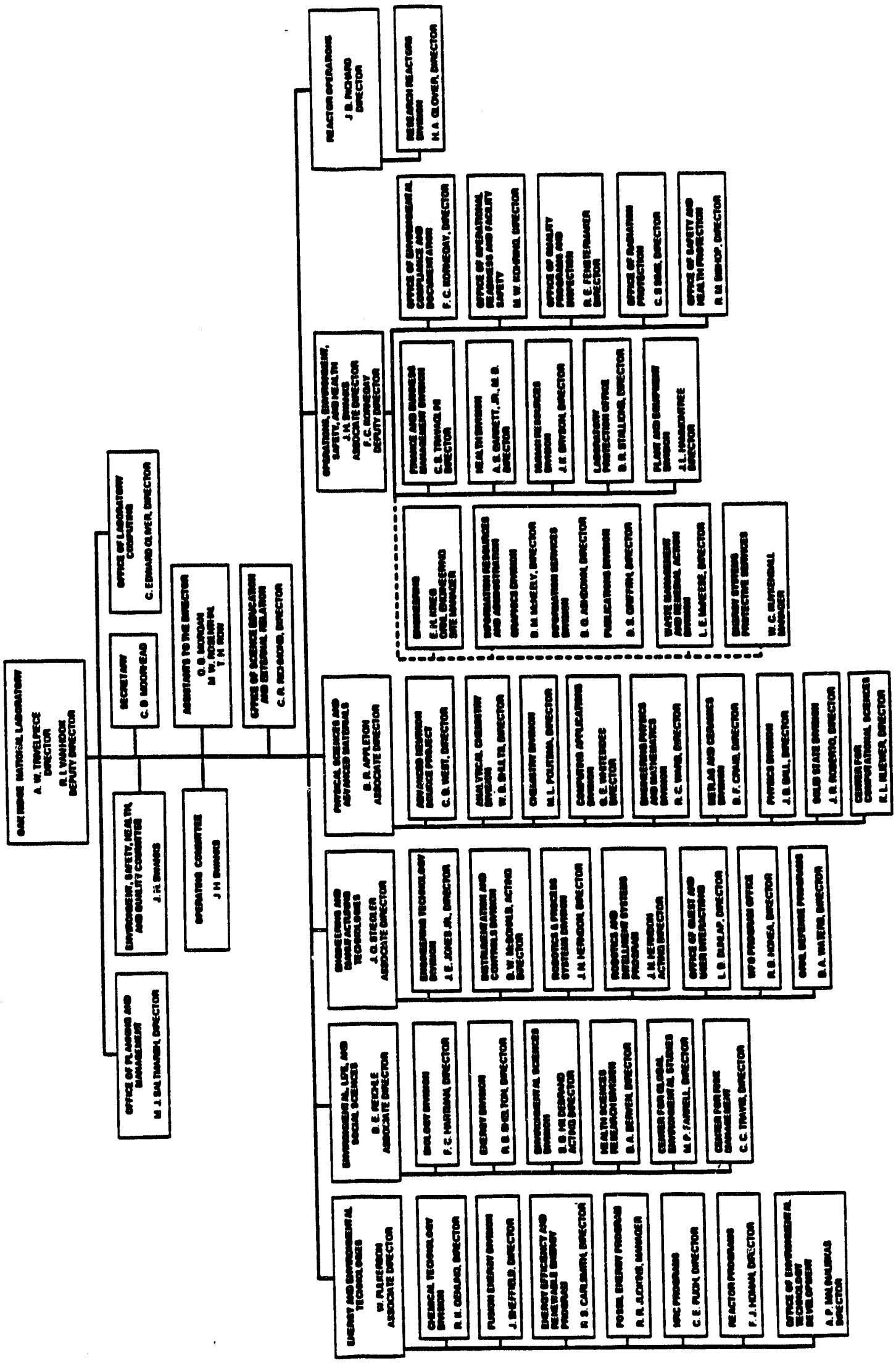


\section{APPENDIX D}

\section{CALCULATION OF CRITICAL TEMPERATURE \\ OF IRIDIUM TARGET ROD, CORRESPONDING \\ TO RUPTURE OF TARGET-ROD SHEATH}

It is assumed for this calculation that failure of the target-rod sheath takes place when the hoop stress equals the ultimate strength of the material, ignoring dimensional changes. The properties of the material (6061 aluminum) are uncertain because of annealing effects during fabrication (welding of ends) and heatup in the cask. Radiation damage is expected to be negligible (Ref. 1). Before welding, the material is in the T6 condition. Reference 2 indicates that above $400^{\circ} \mathrm{F}$ the ultimate strength is about the same for the T6 and T4 conditions but is much less for the T0 condition (Fig. D.1)

The hoop stress is the result of steam generation inside the target rod. The pressure stress is calculated from

$$
\sigma=\frac{\mathrm{pa}}{\mathrm{t}}
$$

where

$$
\begin{aligned}
& \sigma=\text { hoop stress, } \\
& p=\text { internal pressure, } \\
& a=\text { radius of sheath }=0.215 \mathrm{in} . \\
& t=\text { wall thickness of sheath }=0.0275 \mathrm{in} .
\end{aligned}
$$

It is assumed that at the time of rupture there is still some liquid phase in the target rod, and thus saturation conditions exist. The corresponding relationship between temperature and pressureinduced stress [Eq. (D.1)] is shown in Fig. D.2 and the relationship between pressure and temperature for saturated conditions is shown in Fig. D.3 (data taken from steam tables).

The ultimate strength is also a function of temperature, and the corresponding relationships (Ref. 2) for the T6/T4 and T0 conditions are also included in Fig. D.2.

The intersections of $t:$ applied-load vs temperature curve and the two ultimate-stress vs temperature curves represent the extremes of the possible failure points, and the corresponding critical values of temperature, pressure, and stress are $600^{\circ} \mathrm{F}, 1500 \mathrm{psi}$, and $10,000 \mathrm{psi}$, respectively, for the T6/T4 condition and $470^{\circ} \mathrm{F}, 500 \mathrm{psi}$, and $4000 \mathrm{psi}$ for the $\mathrm{T} 0$ condition.

The end welds were made without chill blocks, which could have prevented substantial heating of the target rods away from the ends and thus prevented annealing. A simplified calculation (see 
Appendix E) indicates that during the welding process and without the chill blocks, the temperature 2 inches from the end would reach $\sim 1000^{\circ} \mathrm{F}$. Although the time at this temperature would be short, it is expected that the amount of annealing would be substantial (Ref. 2). Thus, it is likely that the critical temperature was of the order of $500^{\circ} \mathrm{F}$, rather than $600^{\circ} \mathrm{F}$.

A precise determination of the critical temperature is not important for this investigation. It is only necessary to show that the critical temperature is achievable. Calculations included in Ref. 3 indicate that when target rod IR-75 was in the cask, its peak temperature was $\sim 840^{\circ} \mathrm{F}$. Thus, the calculations indicate, with substantial margin for error, that the critical temperature was achieved while target rod IR-75 was in the cask.

\section{References}

1. Personal communication with K. Farrell, ORNL

2. Aerospace Structural Materials Handbook, AFML-TR-68-115, 1979.

3. A. L. Longest, ORNL, "Thermal Analysis for Iridium Transport Cask After Removal from HFIR Pool on September 7, 1993," letter to R. D. Cheverton, ORNL, November 10, 1993. 


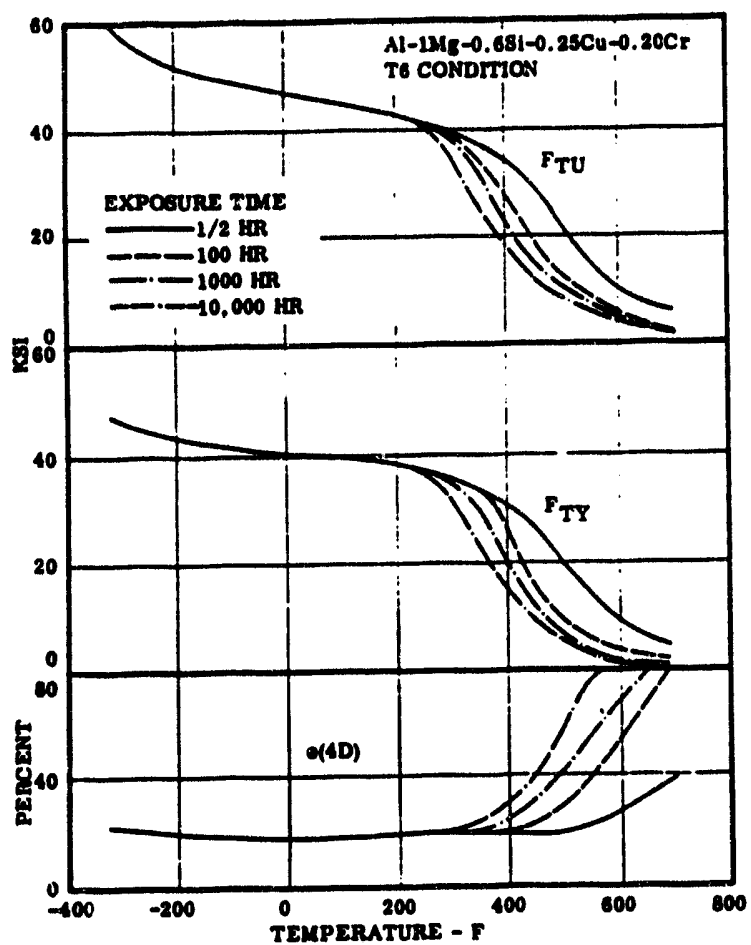

FW. 3.0315 EFrECT OF EXPOSURE AND TEST TEMPERATURE ON TENBILE PROPE RTES OF ALLOY DN T6 CONDITLN. (0)

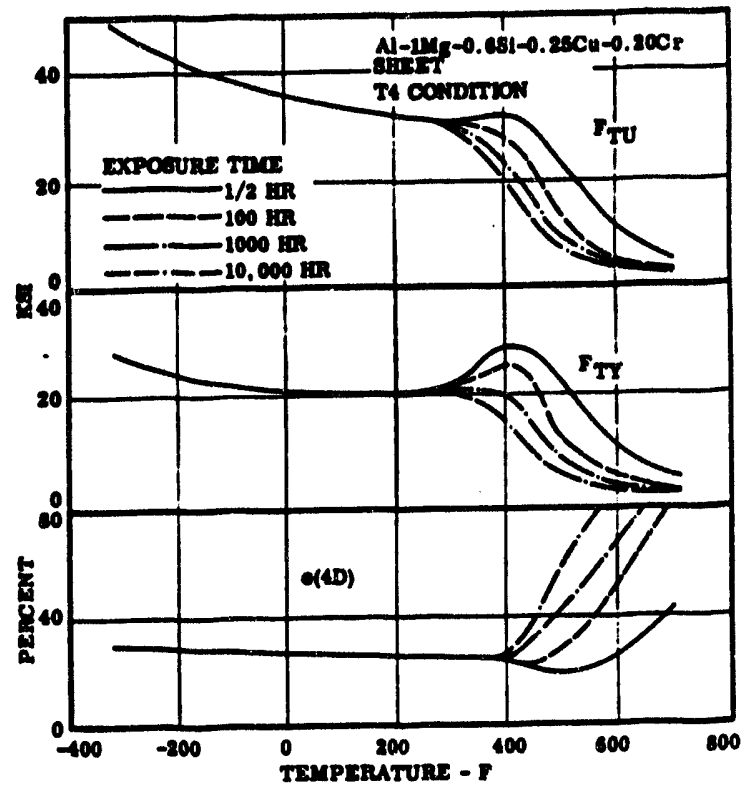

FT. 3.0914 EPTECT OF EXPOSURE AND TEST TEMPERATURE ON

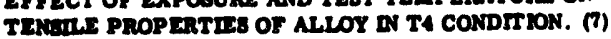

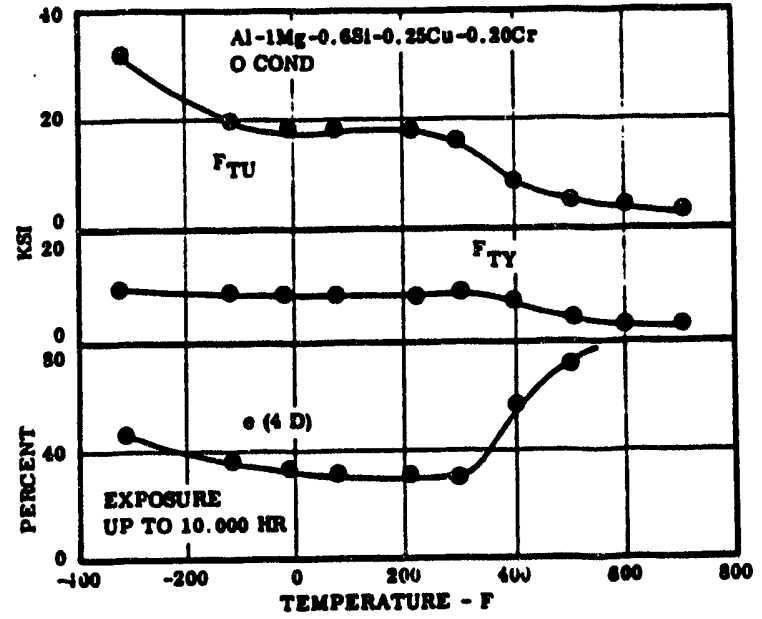

Fx. 3.012 EFTECT OF Exposune AND TEST TEMPERATUR ON TENALE PROPERTLE OF ALLO $\mathrm{n}$ O CONDTTION.

Fig. D.1. Tensile properties for 6061 aluminum in the T0, T4, and T6 conditions (Ref. 2). 


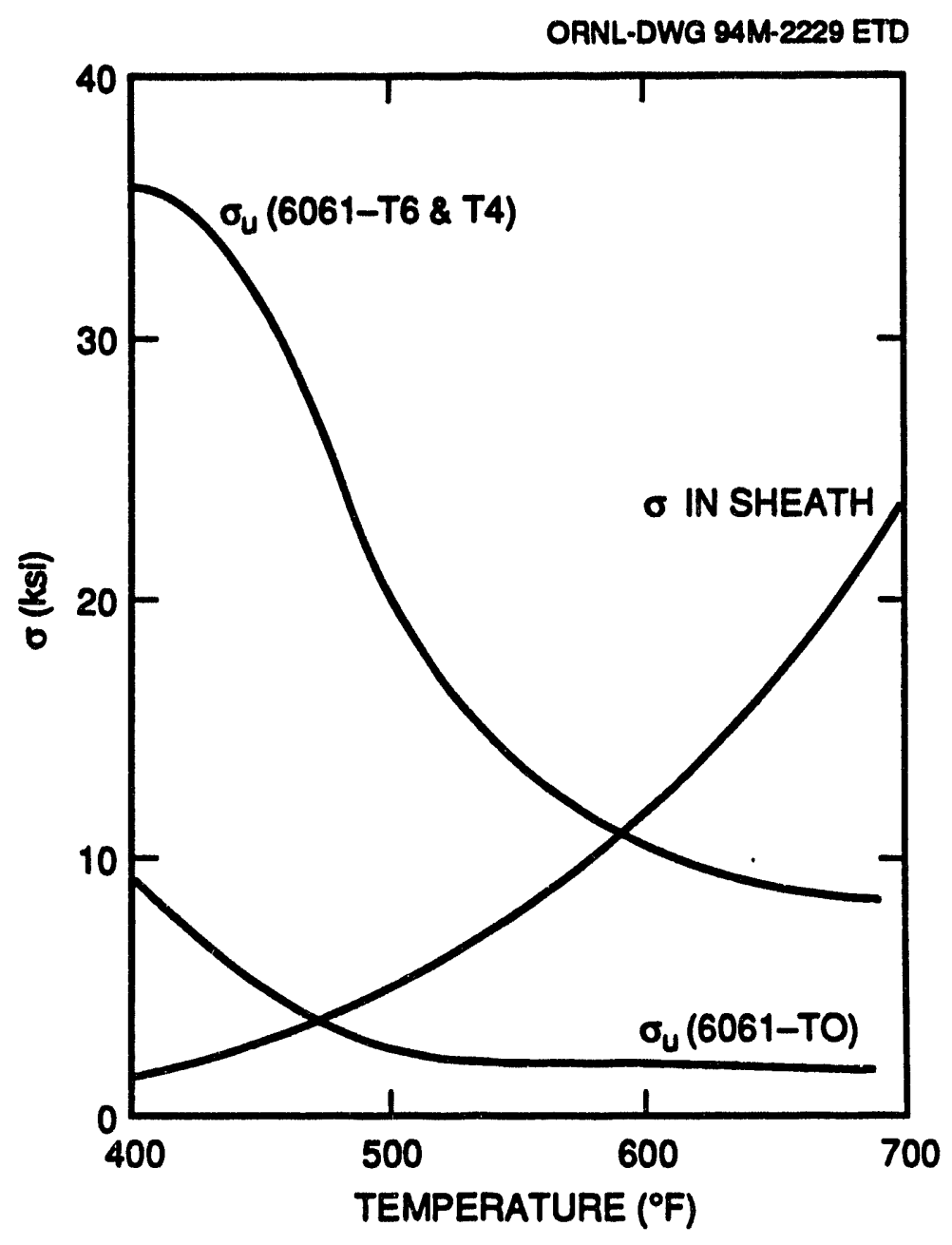

Fig. D.2. Calculated critical temperatures corresponding to rupture of a HFIR iridium target rod containing water. 


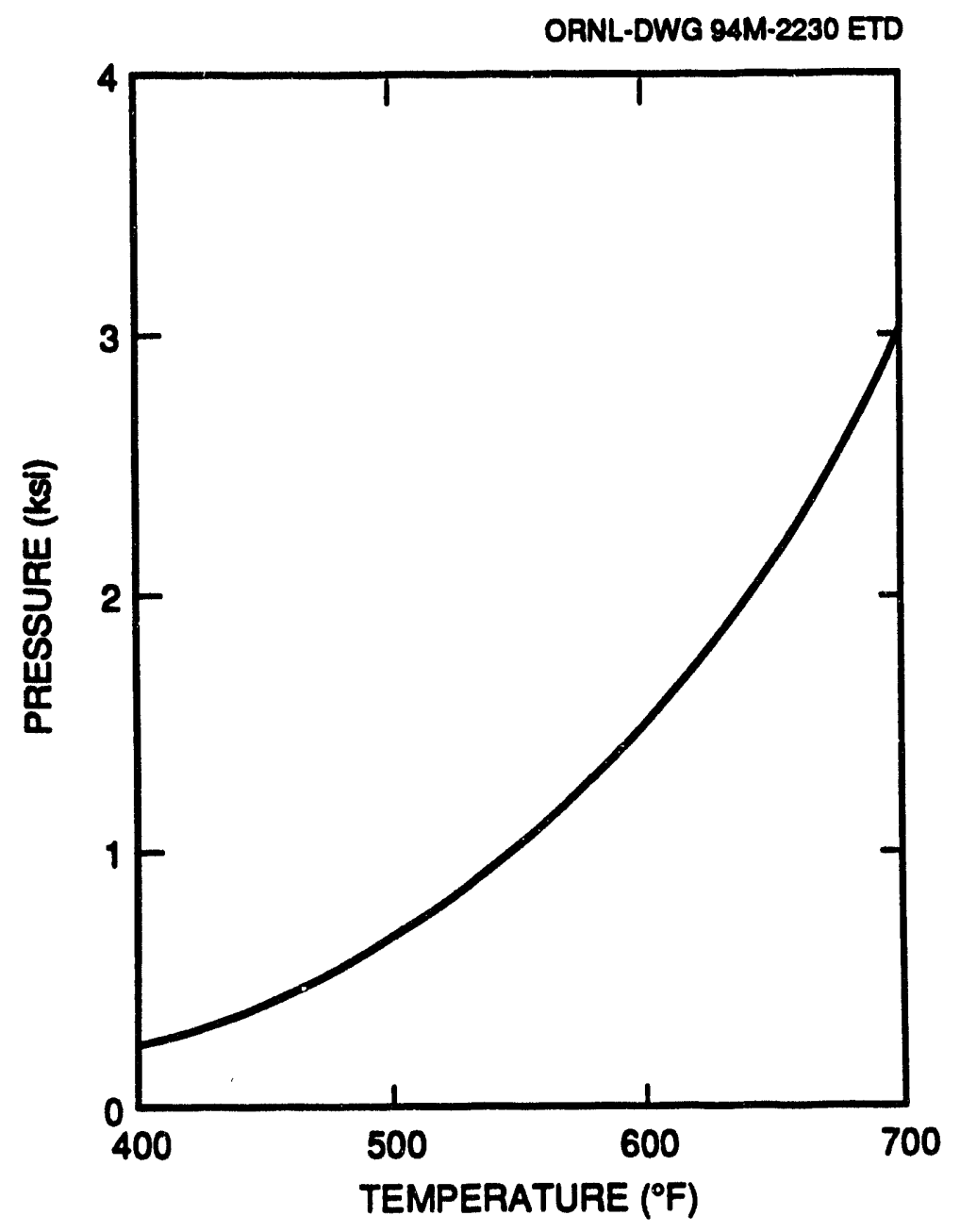

Fig. D.3. Saturation pressure vs temperature for steam. 


\section{APPENDIX E}

\section{CALCULATION OF TEMPERATURE ALONG LENGTH OF IRIDIUM TARGET ROD WHILE END WELD IS BEING MADE}

Fabrication of the target rods includes welds at either end that attach the sheath to the core. The welds are made without the use of chill blocks, which could have reduced the temperature increase in the portions of the rod beyond the chill blocks and which are often used for similar situations. The question that arises as a part of this investigation is whether the temperature at the location of the rupture ( 2 inches from the end) was high enough during welding to substantially anneal the material, reducing the material's strength well below that associated with the $\mathrm{T} 6$ condition.

A simplified analysis is made using a semi-infinite body (no radial heat transfer from the target rod), with the temperature on the end of the target rod maintained at $1300^{\circ} \mathrm{F}$ (slightly above the melting temperature). The initial temperature of the target rod is assumed to be $\sim 200^{\circ} \mathrm{F}$ (welded soon after removal from drying oven). The method of analysis is that in Ref. 1 , in which the following parameters are defined:

$$
\begin{gathered}
\mathrm{X}=\frac{k \theta}{p c_{p} x^{2}}, \\
\mathrm{~m}=\frac{\mathrm{k}}{\mathrm{hx}}, \\
\mathrm{y}=\frac{\mathrm{t}^{\prime}-\mathrm{t}}{\mathrm{t}^{\prime}-\mathrm{t}_{\mathrm{b}}}, \text { or } \mathrm{t}=\mathrm{t}^{\prime}-\mathrm{y}\left(\mathrm{t}^{\prime}-\mathrm{t}_{\mathrm{b}}\right),
\end{gathered}
$$

where

$$
\begin{aligned}
& \mathrm{k}=\text { thermal conductivity }=125 \frac{\mathrm{Btu} \cdot \mathrm{ft}}{\mathrm{hr} \cdot \mathrm{ft}^{2} \cdot{ }^{\circ} \mathrm{F}}, \\
& \mathrm{p}=\text { density }=168 \mathrm{lb} / \mathrm{ft}^{3}, \\
& \mathrm{c}_{\mathrm{p}}=\text { specific heat }=0.2 \frac{\mathrm{Btu}}{\mathrm{lb} \cdot{ }^{\circ} \mathrm{F}}, \\
& \mathrm{h}=\text { heat transfer coefficient at end of target rod }=\infty, \\
& \mathrm{x}=\text { distance along length of target rod }=2.0 \mathrm{in} .,
\end{aligned}
$$




$$
\begin{aligned}
& t=\text { temperature at position } x, \\
& t^{\prime}=\text { temperature at end of target } \operatorname{rod}=1300^{\circ} \mathrm{F}, \\
& t_{b}=\text { initial temperature }=200^{\circ} \mathrm{F} .
\end{aligned}
$$

Note: values of $y$, corresponding to values of $X$ and $m$, are obtained from Ref. 1 .

$$
\begin{aligned}
\therefore \quad X & =2.23 \theta \mathrm{min}^{-1} \\
m & =0 \\
t & =1300^{\circ} F(1-0.846 y) .
\end{aligned}
$$

The time to make a weld is about 2 minutes. Thus, temperatures were calculated for 1,2 , and 3 minutes and are included in Table E.1.

Table E.1 Calculated temperature in target rod during welding ( 2 inches from end)

\begin{tabular}{cccc}
\hline $\begin{array}{c}\theta \\
(\mathrm{min})\end{array}$ & $\mathrm{X}$ & $\mathrm{y}$ & $\begin{array}{c}\mathrm{t} \\
\left({ }^{\circ} \mathrm{F}\right)\end{array}$ \\
\hline 1 & 2.23 & 0.36 & 904 \\
2 & 4.46 & 0.25 & 1025 \\
3 & 6.69 & 0.18 & 1102 \\
\hline
\end{tabular}

Actual temperatures may be somewhat less because of heat loss from the target rod that was not accounted for. However, it is likely that the initial temperature and the welding temperature are higher than assumed, and this would tend to make the temperature higher. At any rate, it is reasonably clear that the temperature would be above $775^{\circ} \mathrm{F}$, which is the specified minimum value for annealing (Ref. 2). Even though the material would not be at the elevated temperature for more than a few minutes, it is expected that substantial annealing (loss of strength) would take place (Ref. 3).

\section{References}

1. W. H. McAdams, Heat Transmission, 2nd ed., McGraw-Hill Book Company, New York, 1942, p. 37.

2. Aerospace Structural Materials Handbook, AFML-TR-68-115, 1979.

3. Personal communication with K. Farrell, ORNL. 


\section{APPENDIX F}

\section{CALCULATION OF LONGITUDINAL EXTENT OF END CONSTRAINT PERTAINING TO SHEATH PORTION OF IRIDIUM TARGET ROD}

The location of the rupture in the target-rod sheath is influenced by the longitudinal gradients in material strength and mechanical constraint. The mechanical constraint is manifest in the attachment (weld) of the end of the sheath to the core, and this constraint locally resists displacement of the sheath while the sheath is being pressurized. The constraint effect dampens out along the length of the sheath and is essentially zero at a location described by Ref. 1:

$$
x>\frac{\pi}{\beta} \text {, }
$$

where

$$
\begin{aligned}
& \beta^{4}=\frac{3\left(1-v^{2}\right)}{a^{2} h^{2}} \\
& a=\text { radius of the sheath }=0.215 \text { in., } \\
& h=\text { wall thickness of the sheath }=0.0275 \text { in., } \\
& v=\text { Poisson's ratio, } \\
& \frac{\pi}{\beta}=0.19 \mathrm{in} .
\end{aligned}
$$

This distance is too short to have had a significant effect on the location of the rupture, the midlength of which was 1.5 inches from the end.

\section{Reference}

1. S. Timoshenko, Theory of Plates and Shells, 1st ed., McGraw-Hill Book Co., New York, 1940, p. 395. 
EXHIBIT A

OCCURRENCE REPORT ORO--MMES-X10HFIR-1993-0030 
ORO-MMES-X1OHFIR-1993-0030

OCCURRENCE REPORT

XIOHFIR

- High Flux Isotope Reactor

(Name of Facility)

Category "A" Reactors

(Facility Function)

Oak Ridge National Laboratory

Name:

Title:

(Name of Laboratory site or Organization)

HFIR PLANT MANAGER

Telephone No. (615) 574-8288

Name:

Title:

M B FARRAR

(Facility Manager/Designee)

Telephone No. (615) 576-5009

1. OCCURRENCE REPORT NUMBER: MMES Occurrence Number:

(ORIGINATOR)

ORO--MAES-X1OHFIR-1993-0030

MVES-93-001009 X10 -93-00173

(I0011444)

2. REPORT TYPE AND DATE:

Date

Time

[] Notification Report

[X] 10 Day Report

[ ] 10 Day Update (latest)

$09 / 08 / 1993$

$1 /$

$14: 00$

[ ] Final Report

3. OCCURRENCE CATEGORY:

[ ] Emergency

[X] Unusual

[ ] Off-Normal

[ ] Non-Routine

[ ] Void

4. DIVISION OR PROJECT:

Research Reactors

5. DOE PROGRAM OFFICE:

NE - Nuclear Energy 
6. SYSTEY, BLDG., OR EQUIPMENT: 7900

7. UCNI?
NO

8. PIANT AREA:

Reactor Bay

9. DATE AND TIME DISCOVERED: 09/07/1993 17:30

10. DATE AND TIME CATEGORIZED: 09/07/1993 18:30

11. DATE AND TIME OF DOE NOTIFICATION:

09/07/1993 20:15 R A HONTER / DOE-HQ

12. DATE AND TIME OF OTHER NOTIFICATIONS:

09/07/1993 20:15 D D AUSMUS / LAB. PRO

09/07/1993 20:15 R E DANIELS / DOE

09/07/1993 20:15 J CANNON / DOE-HO

09/07/1993 20:15 B WIITIS / DOE

09/07/1993 20:15 E REEVES / DOE-HQ

13. SUBJECT OR TITIE OF OCCURRENCE:

Radiation Alarm Initiated a Building Evacuation

14. NATURE OF OCCURRENCE:

II Facility Condition - Operational Occurrence

15. DESCRIPTION OF OCCURRENCE:

on September 7, 1993, ten people, including reactor operators, riggers, and health physics personnel were in the reactor bay placing a loaded transfer carrier (HRIEI) on a truck. The carrier contained seven irradiated iridium rods that were being sent to another facility for processing. The transfer carrier had been decontaminated and surveyed, with no abnormal radiation fields found. While lifting the carrier onto the truck, the carrier was being intentionally tilted to a horizontal position. When the carrier reached approximately 60 degrees from the horizontal, the southeast reactor bay monitron (radiation monitor) alarmed on high level shortly followed by a Facility Radiation Monitoring System (FRMS)-initiated building evacuation horn, causing a building evacuation. At the same time, individual "chirpers" (personal audible pocket radiation monitors) indicated suddenly increasing radiation levels. The carrier was returned to a vertical position.

At 1330 on september 8, 1993, after its exit from the reactor bay, contamination was found on the robot that had been used 
for dose measurements around the HRLEL carrier. A 60,000 dpm particle was found on the front left tire and was identified as iridium-192. Other fixed particles ranging from 4,000 to $12,000 \mathrm{dpm}$ were also found on the tires and were identified as iridium-192.

16. OPERATING CONDITIONS OF FACIIITY AT TIME OF OCCURRENCE:

The reactor was in a normal, end-of-cycle refueling outage.

17. ACTIVITY CATEGORY:

Transportation

18. IMMEDIATE ACTIONS TAKEN AND RESUITS:

The reactor building was evacuated. A building search was directed by the local emergency supervisor. The Research Reactors Division emergency response team was activated and the Laboratory Shift superintendent was notified. All evacuated personnel at the assembly point were surveyed by health physics. All personnel were accounted for. No personnel contamination was found. The maximum estimated individual exposure was $55 \mathrm{mrem}$ (based on pocket dosimetry). All activities in the building were secured. A critique was initiated. The Tennessee Department of Environment and Conservation (TDEC) and the Director, Division of Environmental Epidemiology of the Tennessee Department of Health were notified. The office of Nuclear safety was notified.

The 60,000 dpm particle found on the robot tire was easily removed. The other fixed particles on the robot tires were removed except one that was covered $(4,000 \mathrm{dpm})$.

19. DIRECT CAUSE:

20. CONTRIBUTING CAUSE(S):

21. ROOT CAUSE:

\section{DESCRIPTION OF CAUSE:}

The iridium-192 contamination found on the robot tires indicates a breach in an iridium target capsule and icicium contamination on the floor in the reactor bay. 
ORO--MAES-X1OHFIR-1993-0030

Ten-day Report

OCCURRENCE REPORT

Page 4 of 6

Robot and personnel entries into the reactor bay indicate approximately $5 \mathrm{R} / \mathrm{h}$ radiation field around the transfer carrier with a hot spot of approximately $450 \mathrm{R} / \mathrm{h}$ at the southmost bottom corner of the carrier.

A multi-disciplined situation management task team has been formed and is evaluating the situation. The team will be responsible for determining the course of action and for coordinating all the associated activities.

Operating crews were able to return to the reactor building late September 7, 1993.

23. EVALUATION: (by Facility Manager/Designee) COST EVALUATION:

The task team will carefully evaluate the situation and determine the best course of action. Further details will be provided as they are available.

24. IS FURTHER EVALUATION REQUIRED:

IF YES, BEFORE FURTHER OPERATION:

IF YES, BY WHOM?HA GLOVIER

BY WHEN? 10/22/1993

25. CORRECTIVE ACTIONS:

26. IMPACT ON ENVIRONMENT, SAFETY, AND HEALTH:

27. PROGRAMMATIC IMPACT:

28. IMPACT UPON CODES AND STANDARDS:

29. FINAL EVAIUATION AND LESSONS IEARNED:

30. SIMIIAR OCCURRENCE REPORT NUMBERS: 
ORO--MAES-XIOHFIR-1993-0030

Ten-day Report

OCCURRENCE REPORT

Page 5 of 6

31. DOE FACIIITY REPRESENTATIVE INPUT:

Entered by:

Date: 
ORO--MYES-X1OHFIR-1993-0030

Ten-day Report

OCCURRENCE REPORT

Page 6 of 6

32. SIGNATURES :

Facility Manager

(Name, Position)

Date:

DOE Facility Representative (Name, Position)

Date:

DOE Program Manager

(Name, Position)

Date: 


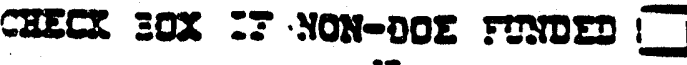

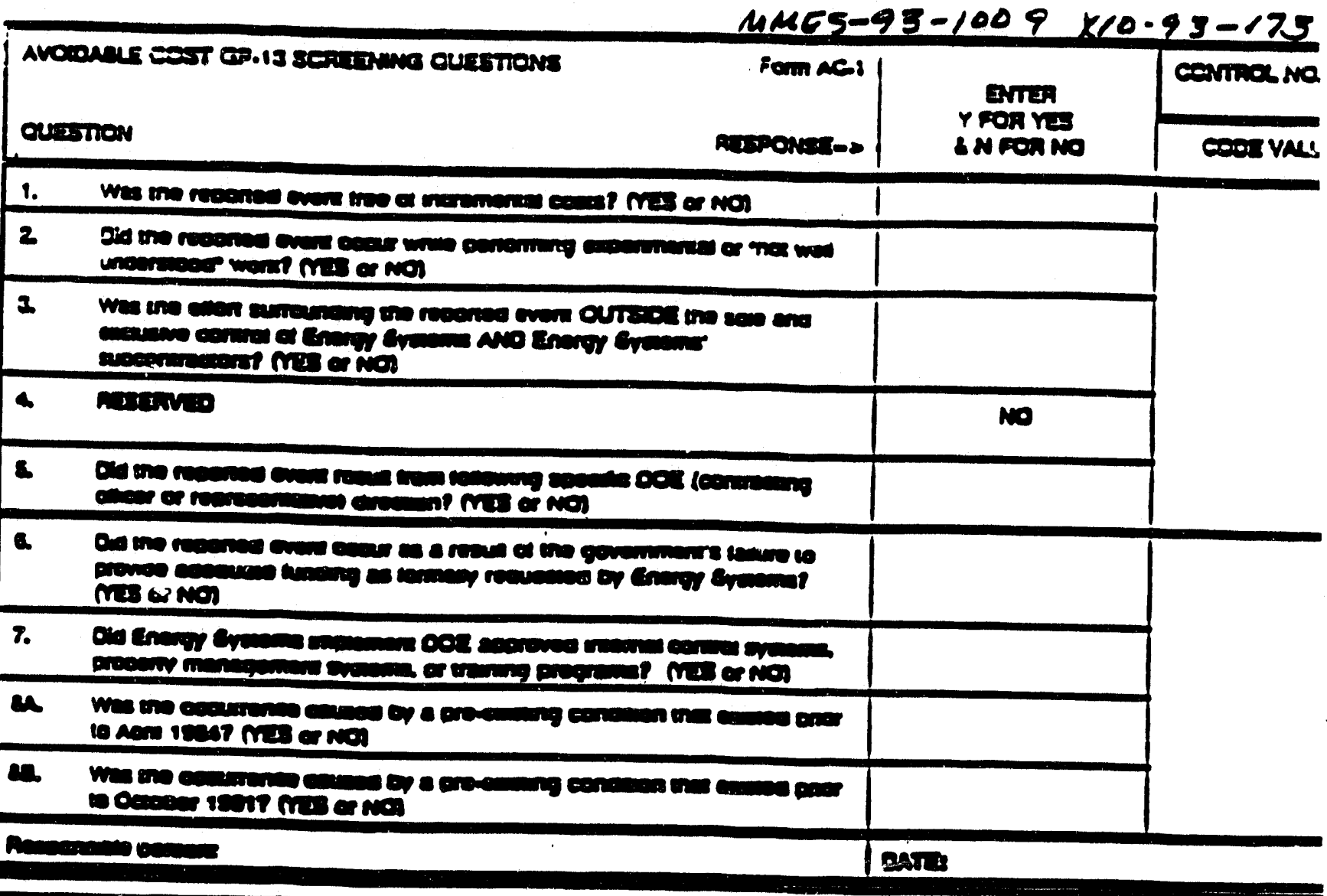

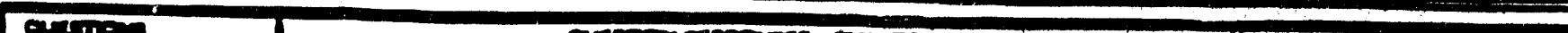

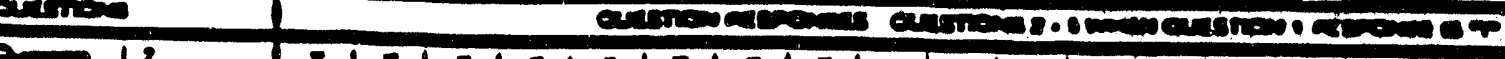

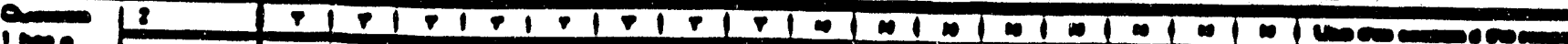

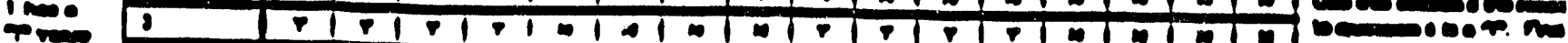
S

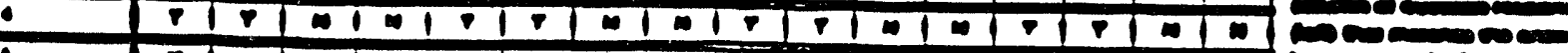
1

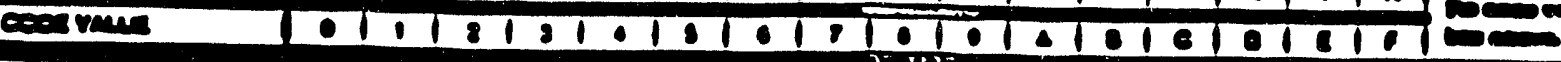

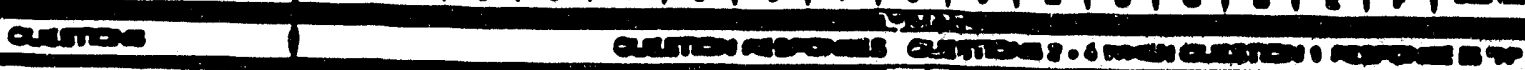

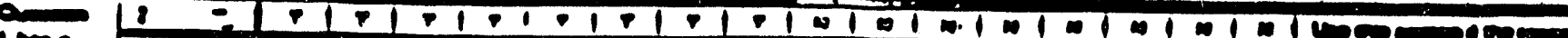

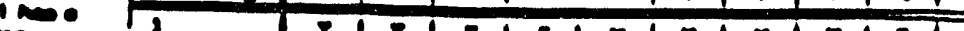

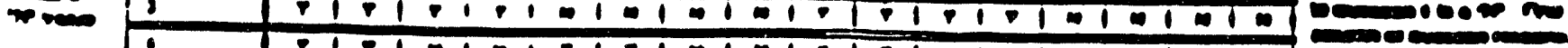

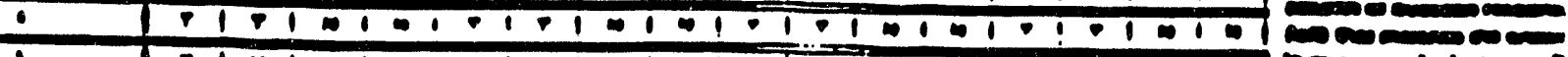

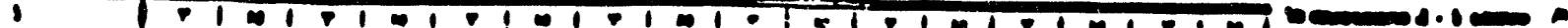

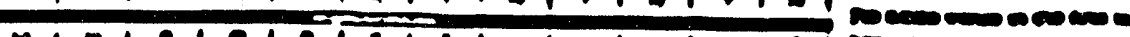

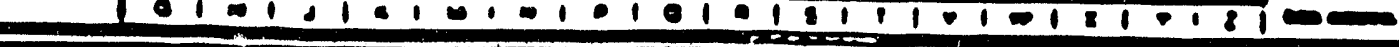

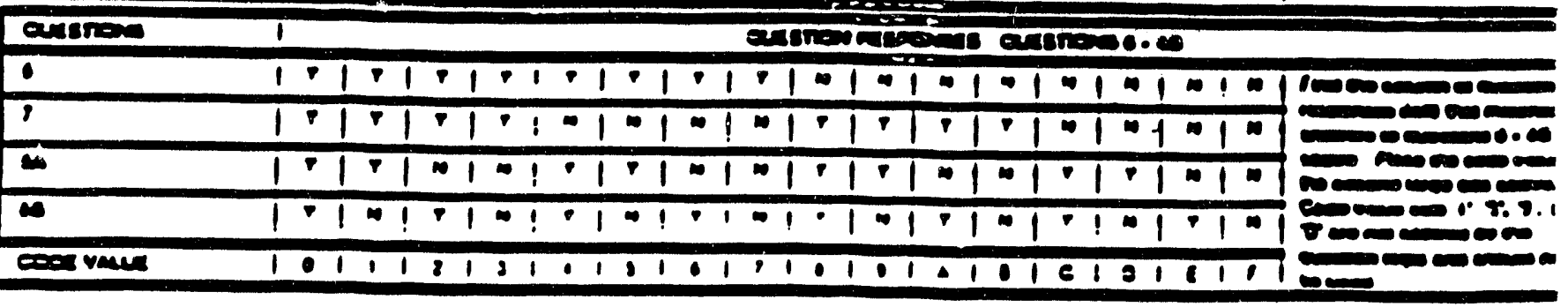
COMAEZTS (ALSO USE BACX) 


\section{Occurrence Report Signoff Sheet}

ORPS Number: ORO-MMIES-X10RFIR-1993-0030

MMES Number: MMIES-93-001009 X10-93-00173

HFIR Number: RIFIR-93-039

Report Date: 09/09/93

\section{SIGNATURES:}

Reviewed by: $\quad$ HM OLminets Authorized Derivative Classifier

Approved by:

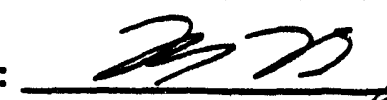

hacilin Manager

Approved by:

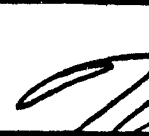

Date: $9 / 9 / 93$

Date: $7 / 9 / 93$

Date: $2-2-28$ 


\section{EXHIBIT B}

MAY 25, 1993, MEMO M. J. SHERICK TO CHUCK OTTINGER 


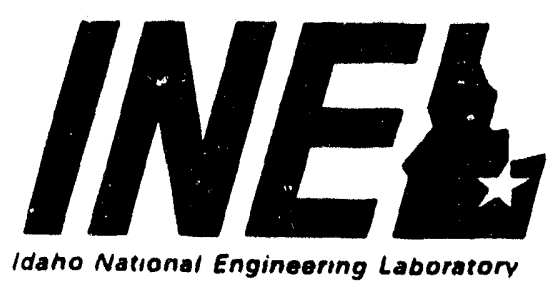

May 25, 1993

Mr. Chuck Ottinger

Mart in Marietta Energy Systems, Inc.

P.0. Box 2008, MS 6385

Oak Ridge, TN 37831

IRIDIUM TARGET CERTIFICATE OF CONFORMANCE - MJS-11-93

Dear Mr. Ottinger:

The purpose of this letter is to provide a Certificate of Conformance for the ORNL standard Ir ${ }^{192}$ targets delivered to you the week of May 25, 1993. I hereby certify that the enclosed target marked OR-IR-72 through OR-IR-101 were fabricated and inspected to EG\&G Idaho, Inc. Drawing 437576,

Revision D, Standards and Specifications (STD-7022, STD-7020, STD-7066 and STD-7008), and the Idaho National Engineering Laboratory Weld Procedure Sperification A2.0. These standards and specifications were transmitted to you with the first ten (10) Iridium targets on January 6, 1992. All material used for fabrication meets the Drawing Specifications.

Certificate of Conformance and Material Certification Analysis reports for the Iridium pellets are enclosed. In addition, these targets were pressure tested to 700 psi and successfully passed helium tests to $2.5 \times 10^{-7} \mathrm{cc} / \mathrm{per}$ second. All targets sustained an oven bake prior to welding to assure absence of moisture. Per your request, stock material samples of the aluminum used in fabrication for your analysis were given to you on November 12, 1992, at the Fall Isotope Working Group meeting at the Oak Ridge National Laboratory.

If you have any questions, please contact me on (208) 526-4212.

Sincerely,

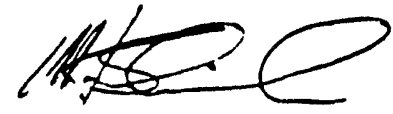

M. J. Sherick

Experiment Project Management

sjh

Enclosure:

As Stated

EC: (wio Encl)

F. C. Fogarty, EGAG Idaho, MS 7117

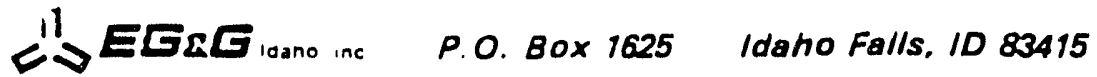


EXHIBIT C

EXPERIMENTAL SAFETY ASSESSMENT, ESA-HFIR-92-1 


\section{Experiment Safety Assessment}

ESA-HFIR-92-1

Irradiation of INEL Iridium Targets in the HFIR SVXF

$\frac{\text { Pufleds }}{\text { Prepared By }}$
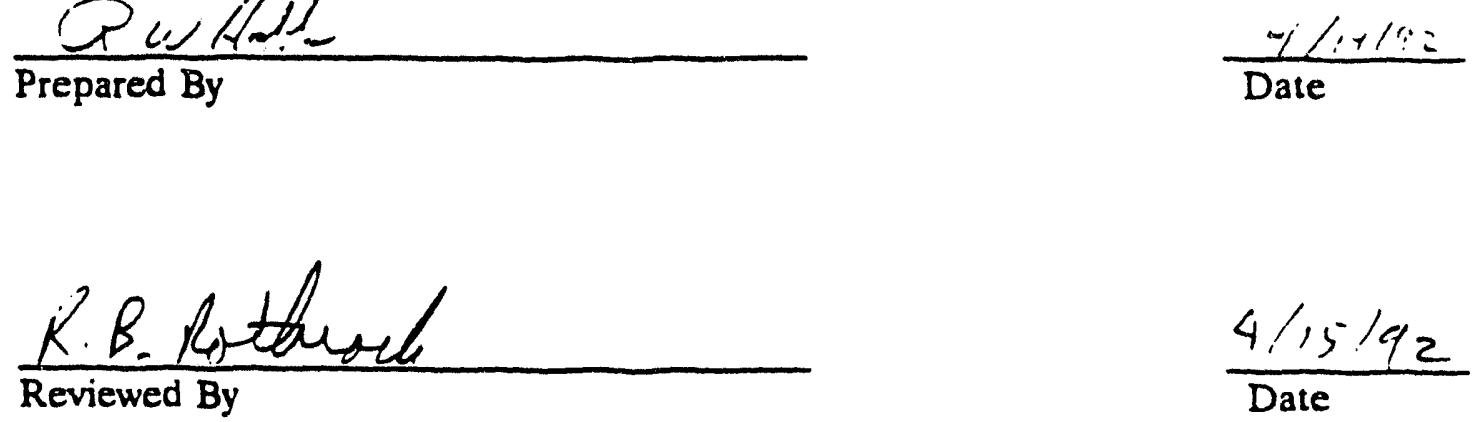

Sene Hem

Reactor Techrology Section Head
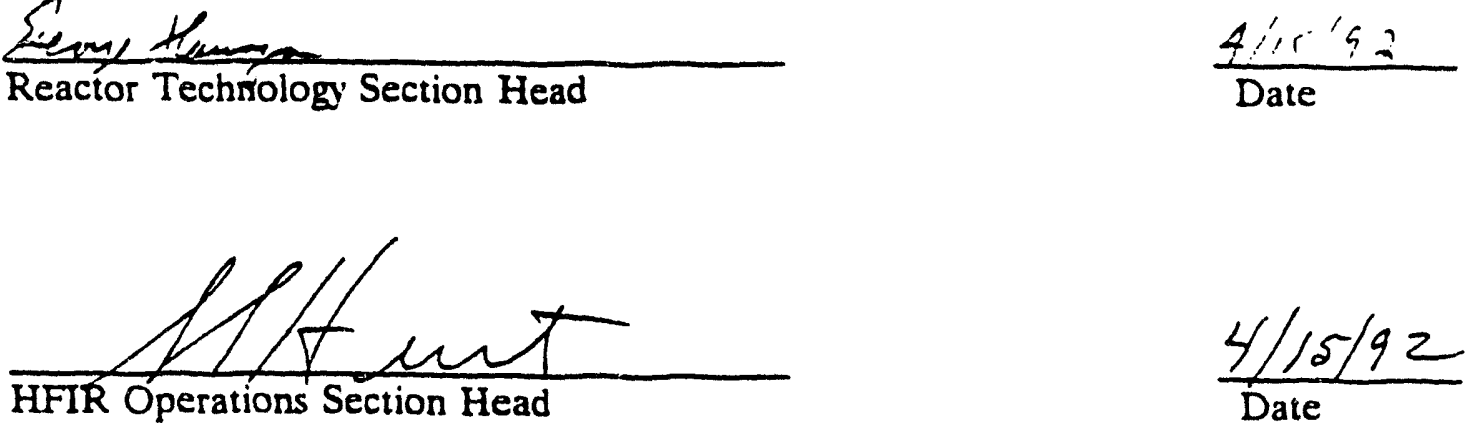

Office of Operational Readiness and Safety

Date 
ESA-HFIR-92-1

Page 2 of 5

Irradiation of INEL Iridium Targets in the HFIR SVXF

\subsection{Introduction}

It is proposed to irradiate. on a routine basis. Iridium targets fabricated by Idaho National Engineering Laboratory (INEL) in the small Vertical Experiment Facilities (VXF) positions of the High Flux Isotope Reactor (HFIR). The Iridium 192 produced by the activation of natural Ir is used primarily for nondestructive examination of welds via gamma radiography. Currently the Iridium targets are being irradiated in the Advanced Test Reactor (ATR) at INEL but the market demand is such that INEL cannot supply the desired quantities. HFIR produced Iridium will therefore augment the INEL production.

In the past. Iridium targets of a different design and fabricated at ORNL have been routinely irradiated in the HFIR. Due to the difference in the ORNL and INEL iridium target designs, the irradiation of the INEL. Iridium targets is being treated as a new experiment.

This document summarizes the Research Reactor Division (RRD) review and assessment of the effect of the routine irradiations of INEL fabricated Iridium targets in the HFIR SVXF on reactor safety, personnel safery and reactor operations. This summary document, coupled with the Nuclear Safety Assessment Checklist and Basis (Ref.1), the Experiment Information and Safery Analysis Form (Ref. 2), and capsule drawings (Ref. 3), constitute the safety assessment for the INEL iridium target irradiations.

\section{Brief Description of Experiment}

The INEL Iridium target is shown in figure 1. It consists of an inner heavy walled aluminum tube (.420" OD X $.25^{\prime \prime}$ I.D X 16") whose outer surface contains numerous "dishes" (726) into which small Iridium pellets (.107" Dia. X .011" thick) are placed. A thin walled outer sleeve of Aluminum (.485" O.D X .430 I.D X 15.75") is slid over the "dished" inner tube as the pellets are loaded and upon completion of loading. filet welds are made at both ends to seal the outer and inner tubes. The total iridium loading is nominally 25.4 grams per target.

Up to 3 iridium targets are loaded into a " 3 hole" Aluminum holder (figure 2) and the holder is placed into an orificed VXF facility liner tube (fig 3 ) for irradiation. Coolant flow' paths are shown schematically in figure 4.

Note. the orificed VXF facility liner tube (fig. 3) is an existing component used in past isotope irradiations conducted in the VXF sites. When an isotope target holder is not to be loaded into the facility liner tube, the liner tube in the inner small VXF's remains empty in the reactor and in the outer sinall VXF's it may remain empty or be removed and replaced with a beryllium plug. Thus, the only new components are the INEL iridium targets (fig. 1) and target holder (fig. 2).

\subsection{Irradiation Position and Schedule}

The iridium targets will be irradiated for nominally 1 to 2 cyclcs in the inner small VXF positions and nominally 2 to 3 cycles in the outer small VXF positions. The 3 hole holder may contain from 1 to 3 iridium targets. If only 1 or 2 iridium targets are loaded, the remaining hole(s) will be left empty. Depending upon market demand all available small VXF sites may be used at one time. 
ESA-HFIR-92-1

Page 3 of 5

Irradiation of INEL Iridium Targets in the HFIR SVXF

\subsection{Safety Summary}

Risks associated with the irradiation of the INEL iridium targets are minimal and acceptable. All applicable HFIR technical specifications relevant to the conduct of experiments are met (see table 1).

Although Iridium is a strong neutron absorber, past operating experience with the irradiation of ORNL produced Ir and Eu (also a strong neutron absorber) targets in the VXF positions has shown that reactivity effects are essentially zero due to the distance between the core and the VXF irradiation sites.

Heat transfer calculations indicate that under normal operating conditions the capsule is more than adequately cooled with surface temperatures $\left(142^{\circ} \mathrm{F}\right.$ max $)$ and internal aluminum temps $\left(146^{\circ} \mathrm{F}\right.$ max $)$ temperatures only slightly above reactor coolant temperatures $\left(130^{\circ} \mathrm{F}\right)$. The temperature of the iridium pellets is sensitive to the contact resistance between the pellet and aluminum holder and is in the range of $146^{\circ} \mathrm{F}$ (perfect contact with holder) to $580^{\circ} \mathrm{F}$ (minimal area contact with the holder.) The lower target coolant outlet holes in the 3 hole target holder (fig.2) have been designed to provide the major portion of the pressure drop across the target holder. As a result. the target holder flow distribution and target cooling is not sensitive to the target loading (i.e., with 1.2 or 3 iridium targets loaded into the 3 hole holder the coolant low past each target remains at -2 gpm.no flow bypass situation is created). The potential for overheating due to complete flow blockage is viewed to be negligible and certainly no greater than with other experiment assemblies currently operating in the HFIR. Therefore no concerns associated with target cooling during normal (full power, full flow) reactor operations have been identified.

It should be noted that the heat generation due to the decay of ${ }^{192} \mathrm{Ir}$ and ${ }^{194} \mathrm{Ir}$ is a significant fraction of the total heat generation (approximately 450 watts/target out of 800 watts/target or $=56 \%$ is due to Ir decay). Therefore shortly after reactor shutdown following cutoff of the main primary coolant pumps and depressurization of the reactor, heat transfer conditions for the iridium targets will probably worsen. Heat transfer under these conditions (pony motor flow or no flow) has not heen evaluated. It is known that Iridium targets of the ORNL. design have been irradiated in higher flux positions in the RB (and therefore comparable or higher decay heat generation rates) with no adverse effects on the physical integrity of the targets. Thus it is not expected that post shutdown heat transfer conditions will jeopardize the integrity of the INEL targets when irradiated in the VXF position. An analyses of this situation will be required prior to commencing irradiations and be documented in an appendix to this safety assessment.

If a small crack (i.e., not big enough for a pellet to escape) were to occur in the iridium target during operation, reactor coolant would enter the target. However because internal capsule ttmperatures are low, no net internal pressure (beyond reactor.coolant pressure) would develop. Also iridium is highly corrosion resistant and contamination of the reactor coolant from any water that might leach back out of the crack would not be a concern. The capsule end welds (the area most susceptible to small cracks) are Helium leak checked after assembly. Therefore the development of a small crack in the target during reactor operation would not be a concern. 
ESA-HFIR-92-1

Page 4 of 5

Irradiation of INEL Iridium Targets in the HFIR SVAF

Therefore, the only envisioned means of creating a potential reactor concern is to generate a crack large enough to release some of the iridium pellets into the reactor coolant. If this were to occur the iridium pellet(s) would most likely be entrained in the reactor coolant flow and subsequently be captured on the inlet coolant strainer or crevice in the heat exchanger and would present no safery concern. It is conceivable. although highly unlikely, that the released pellet could also be trapped between a control element component in such a way as to bind its movement. Juch an event would not initiate a reactor accident. and since at most it would probably effect only one control element the reactor could still be shut down.

To create a crack large enough to release a pellet would require the generation of internal pressure within the capsule. Since the capsule operates at relatively low internal temperatures, and has a small void volume, the development of excessive internal pressure due to waterlogging (i.e.. inleakage of water during a cold shutdown. and development of pressure due to temperature increases upon return to full power) is not likely. The only other envisioned means to generate internal pressure would be improper cleaning procedures (i.e., leaving organics or other volitale material sealed within the capsule). The cleaning procedures used by INEL have been reviewed and will incorporate oven drying at $220^{\circ} \mathrm{C}$ for 15 minutes just prior to welding of the assembly to ensure all traces of volatile material are removed. To date $=300$ of the INEL targets have been irradiated without incident in the ATR under conditions of similar pressure (350 vs 460 psig extemal pressure) and higher heat generation and surface heat flux $\left(1 \times 10^{5} \mathrm{BTU} / \mathrm{HR} / \mathrm{FT} 2\right)$ vs $\left.3.4 \times 10^{4} \mathrm{BTU}^{\mathrm{H} / \mathrm{HR} / \mathrm{FT}^{2}}\right)$.

Therefore the probability of a capsule rupture which would release pellets, and the consequences of such an event are low enough to pose no increase in risk to the operational safety of the reactor.

It should be noted, that although no iridium targets have failed in the ATR. problems have been experienced with what appear to be weld failures occurring after discharge of the target from the reactor. It is believed by INEL personnel that small cracks in the welds are developed from postirradiation handling of the targets (i.e.. the targets are dumped onto a table and then transferred from $-120^{\circ} \mathrm{F}$ reactor water to $55^{\circ} \mathrm{F}$ pool water). The result of the small cracks is to admit water into the capsule while it is in underwater pool storage. When stored in pool the targets are adequately cooled and the water presents no problems. After approximately 2 days decay the targets are loaded from the pool into a shipping cask for transfer to the hot cell. During this dry shipment, it is believed that the captured water heats up significantly (due to the Ir decay heat generation) and causes oxidation of the inner Aluminum surfaces making disassembly of the target difficult. Qn occasions hairline cracks in the outer tube isear the heat efiected zone of the welds have been observed by INEL personnel. It is not known if this will be a problem at the HFIR, however, decay times are expected to be greater and there will not be as much target handling.

\subsection{Operational Summan:}

Due to the location in the reactor. the iridium irradiations will not impact the fuel cycle length. The iridium could lower the thermal neutron flux in the pneumatic facility located in VXF-7. Therefore when possible the irradiation sites adjacent to VXF-7 will not be used. The impact on the beam tubes fluxes is not known, but based on previous operating experience with high Eu and Ir loadings in the permanent beryllium this is not expected to be a concern. If it is determined that the Ir adversely effects beam tube fluxes. Ir production will be curaailed. 
No provision exists at the HFIR for the routine handling of individual irradiated INEL iridium targets (fig. 1). Therefore at the HFIR only the target holder (fig. 2) containing the iridium targets will be handled. Tools and procedures currently exist for loading and unloading the target holder into or from the reactor and procedures will be developed and approved for the loading of the target holder (with iridium) into the hot cell shipping cask prior to shipment.

The individual irradiated iridium targets will be removed from the holder and new iridium targets loaded into holder at the $\mathrm{M} \& \mathrm{C}$ hot cells. This will greatly reduce handling by the reactor operator and will aid in reducing reactor outage time. When feasible, the cask loading and transfer of iridium to and from the hot cells will not be scheduled during the reactor outage. This schedule is to aid in reducing outage work and time and is seen to be feasible provided the reactor outage does not exceed 1 week.

\subsection{Operating Constraints}

The conditions for continued routine iridium irradiations are as follows:

1. The irradiations are to be limited to the small VXF sites for irradiation times not to exceed 4 cycles. Limiting the irradiations to the small VXF sites is to ensure the irradiations are within the bounds of this safety assessment. The limit on irradiation time (4 cycles) is arbitrary but expected to satisfy all experiment needs. Request for irradiations outside of these bounds must be approved by RRD with OORFS concurrence.

2. The targets shall be fabricated in accordance with section 12 and attachment $D$ of the Experiment Information and Safety Analyses Form.

3. The experimenter shall report to RRD any indications of weld or target failure that are observed during target dissasembly. 
TABLE 1

INEL IRIDIUM TARGET IRRADIATIONS IN THE SVXF - TECINICAL SPECIFICATION COMPLIANCE

\section{Tochnical Spocilication}

3.8.3.a.(1)(a)
Experiments which can cause a positive reactivity change greater than $0 .(0) 5 \Delta k / k$ and which are movable experiments shall be equipped with a mechanical insertion and removal system having the same reliability as the reactor control system drives. The reactivity insertion rate by these mechanisms shall not exceed $0.00025 \Delta \mathrm{k} / \mathrm{k} \mathrm{s}^{-1}$.

3.8.3.a.(1)(b)
Experiments which can cause a positive reactivity change greater than 0.005 $\Delta \mathrm{k} / \mathrm{k}$ due to motion but which need not be moved while the reactor is critical shall be so firmly supported that no credible circumstances can cause them to be moved while the reactor is critical.

\section{Basis for Compliance}

Experiment is not movable.

Based on past experience with the irradiation of strong absorbers (Ir and Eu isotope targets) in the SVXF positions, reactivity is not a concern. The experiments are firmly supported such that no credible circumstances can cause them to be moved while the reactor is critical.
Technical Specification is met. 
TABLE 1 (cont)

INEL IRIDIUM TARGET IRRADIATIONS IN THE SVXF - TECIINICAL SPECIFICATION COMPLIANCE

Technical Specification

3.8.3.a.(1)(c) Experiments which can cause a positive reactivity change greater than $0.005 \Delta \mathrm{k} / \mathrm{k}$ due to being damaged by temperature or pressure shall be instrumented to cause a reactor shutdown if such temperature or pressure is approached. This is in addition to the safeguards built into the experiment to control the temperature and/or pressure.

3.8.3.a.(1)(d) No experiment may be allowed to cause a reactivity change equivalent to or greater, in effect, than a 1-s ramp insertion of $0.05 \Delta \mathrm{k} / \mathrm{k}$.

\section{Basis for Compliance}

When irradiated in the VXF, the reactivity effect of normal irradiations and highly unlikely target failures due to target damage from pressure or temperature is negligible.

No credible mechanism for introducing this amount of reactivity is identifiable.

\section{Conclusion}

This Tech. Spec. is met.

This Tech. Spec. is met. 
INEL IRIDIUM TARGET IRRADIATIONS IN THE SVXF - TECIINICAL SPECIFICATION COMPLIANCE

\section{Technical Specification}

3.8.3.a.(2) Hydraulic stability. All in-tank experiments shall be designed to withstand the hydraulic forces exerted by the reactor coolant. Bolts, nuts, and screws used in assembly shall be staked, welded, or similarly held to avoid loss into the reactor.

3.8.3.a.(3) lemperature. Heat developed in any experiments by gamma absorption, fissions, electric heaters, etc., shall be dissipated by an adequate coolant flow. Under normal conditions, the temperature of the outer container shall not exceed the saturation temperature of the reactor coolant when the reactor is operated at full power.

3.8.3.a.(4) Explosives. No explosives or mixtures of materials which under credible circumstances can detonate shall be irradiated in the reactor.

\author{
Basis for Compliance
}

The all welded target and target holder design Meets this criteria.

Calculations indicates adequate heat transfer with surface temperature less than saturation temperature. $\mathrm{Q} / \mathrm{A}_{\operatorname{mex}}$ $=3.4 \times 10^{4} \mathrm{BTL} / \mathrm{HR}-\mathrm{Ft}^{2} \mathrm{~F}, \mathrm{~T}$ urfoce $\leq$ $142^{\circ} \mathrm{F}, \mathrm{T}_{\text {mat }}=463^{\circ} \mathrm{F}$.

No explosive materials are contained in the capsule.

\section{Conclusion}

The Tech. Spec. is met.

The Tech. Spec. is met.

The Tech. Spec. is met. 


\section{TABLE 1 (cont)}

NPR-1 REACTOR SAFETY - TECHNICAL SPECIFICATION COMPLIANCE

\section{Technical Specification}

3.8.3.a.(5) Pressure containment. Where failure of pressure-containing walls of an experiment can cause a hazard to personnel or to the reactor, the container must meet the intent of applicable pressure vessel codes. The design for each such container must be reviewed by an appropriate competent engineer and written approval obtained by the Research Reactors Division and the Reactor Experiment Review Committee (RERC).
Experiments shall be designed such that rupture of the beam tube inside the reactor followed by failure of the beam-tube outer flange would not result in a leakage now rate greater than $100 \mathrm{gpm}$ at $1,000 \mathrm{psig}$ differential pressure.

\section{Basis for Compliance}

The iridium target is subject only to external reactor pressure and is subjected to external pressure testing at 700 psig after assembly. Collapse of the outer container tube due to external reactor pressure (468 psig) is therefore not a concern.

Not applicable.

\section{Conclusion}

This Technical Specilication is met.

This Tech. Spec. is not applicable. 
TABLE 1 (cont.)

\section{INEL IRIDIUM TARGET IRRADIATIONS IN THE SVXF - TECHNICAL SPECIFICATION COMPLIANCE}

\section{Tochnical Spocilication}

4.8.3.a.

The Reactor Technology Section of the RRD shall review and examine all experiments proposed for insertion into the reactor for salety, potential hazards, and compatibility with the operation of the reactor and other experiments.

4.8.3.b. New or unusual experiments shall be submitted with recommendations of the Technical Section to the Reactor Experiment Review Committec (RERC) for review in accordance with the provisions of Sect. 6.10 of these Technical Specifications.

4.8.3.c.

Tried experiments may be approved by the Reactor Technology Section without further review by the RERC.
Changes in Technical Specifications or modifications to the plant protection systems reactivity control systems or engineered safety features, or changes that involve a safety question not reviewed in the safety analysis report shall require prior review by the Reactor Operations Review Committee (RORC) and approval by ORNL and DOE.

\author{
Basis for Compliance
}

ESA HFIR-92-1 summarizes this review. RRD judges the risks of capsule operation to be minimal and acceptable. Based on past operating experience with iridium targets of a different design, the conduct of experiment is compatible with reactor operations and other experiments.

The experiment will require $\mathrm{RERC}$ review. RRD review: recommendations are summarized in the approval letter.

Although iridium targets have been routinely irradiated in the SVXF, the INEL target design is sufficiently different to warrant RERC review.

The conduct of this experiment is within the scope of existing Tech Specs. No modifications to these systems have beeil made. As documented in the Nuclear Safety Assessment Checklist, the conduct of the experiment involves no unreviewed safety question.

\section{Conclusion}

The Tech. Spec. is met.

Final approval contingent on RERC review.

This Tech. Spec. does not apply.

This Tech. Spec. is met. 


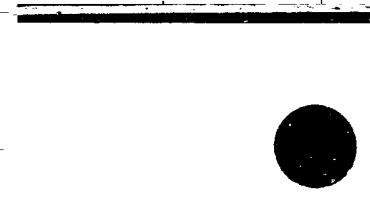

:

2 to Iff Gru:

$38 \cos ^{2}$
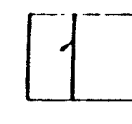

QS

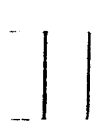

(3)0:- क.

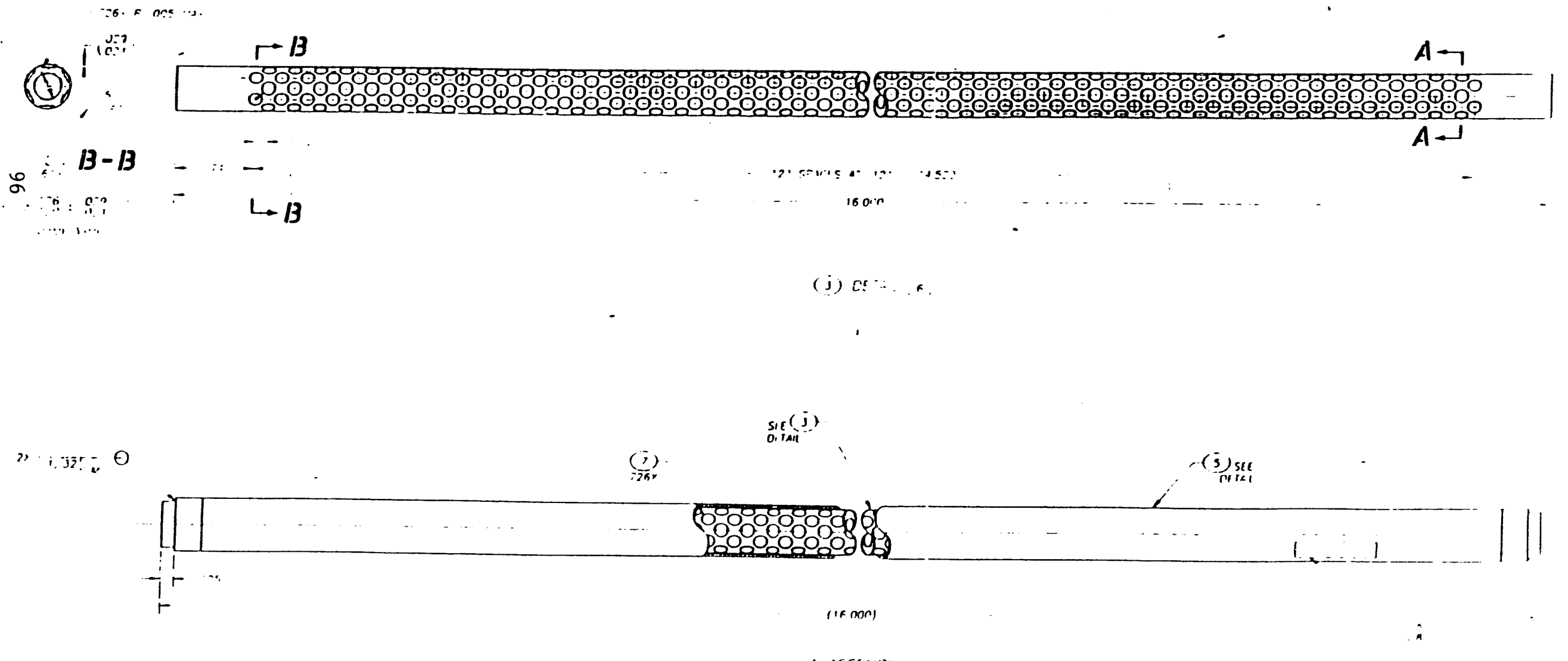




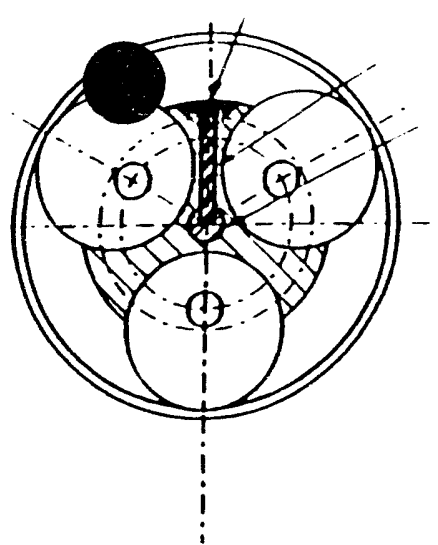

SECTION B - B

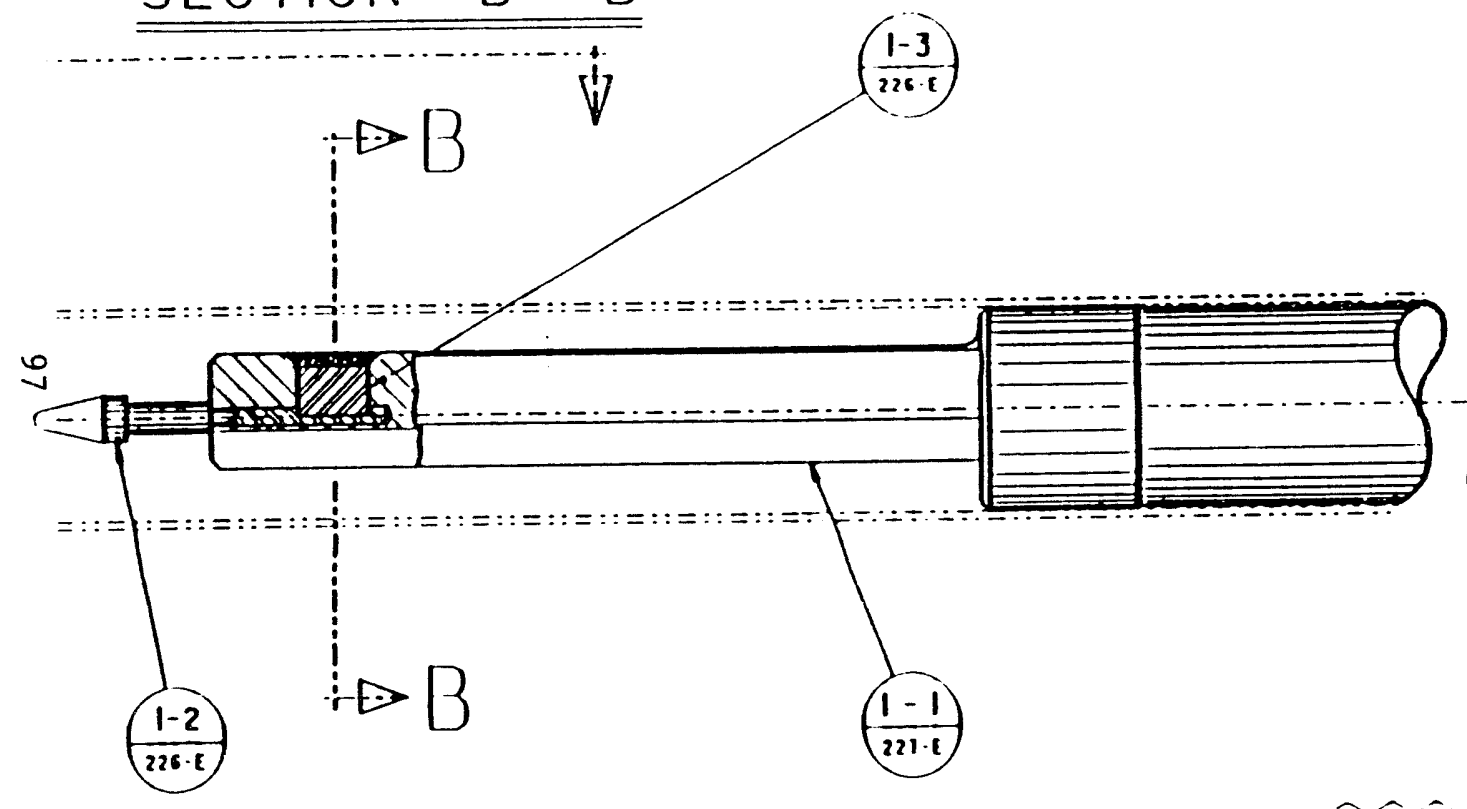

回(2)(3)

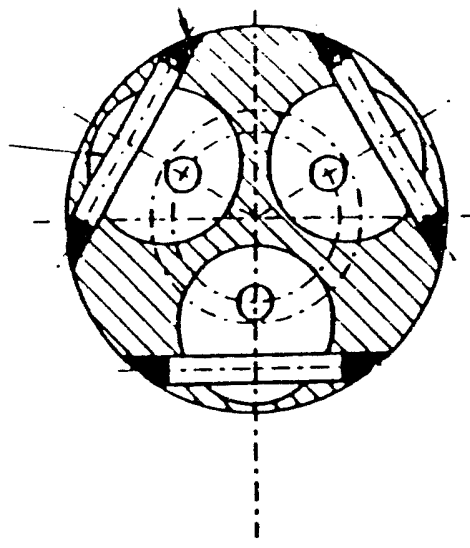

SECTION A-A
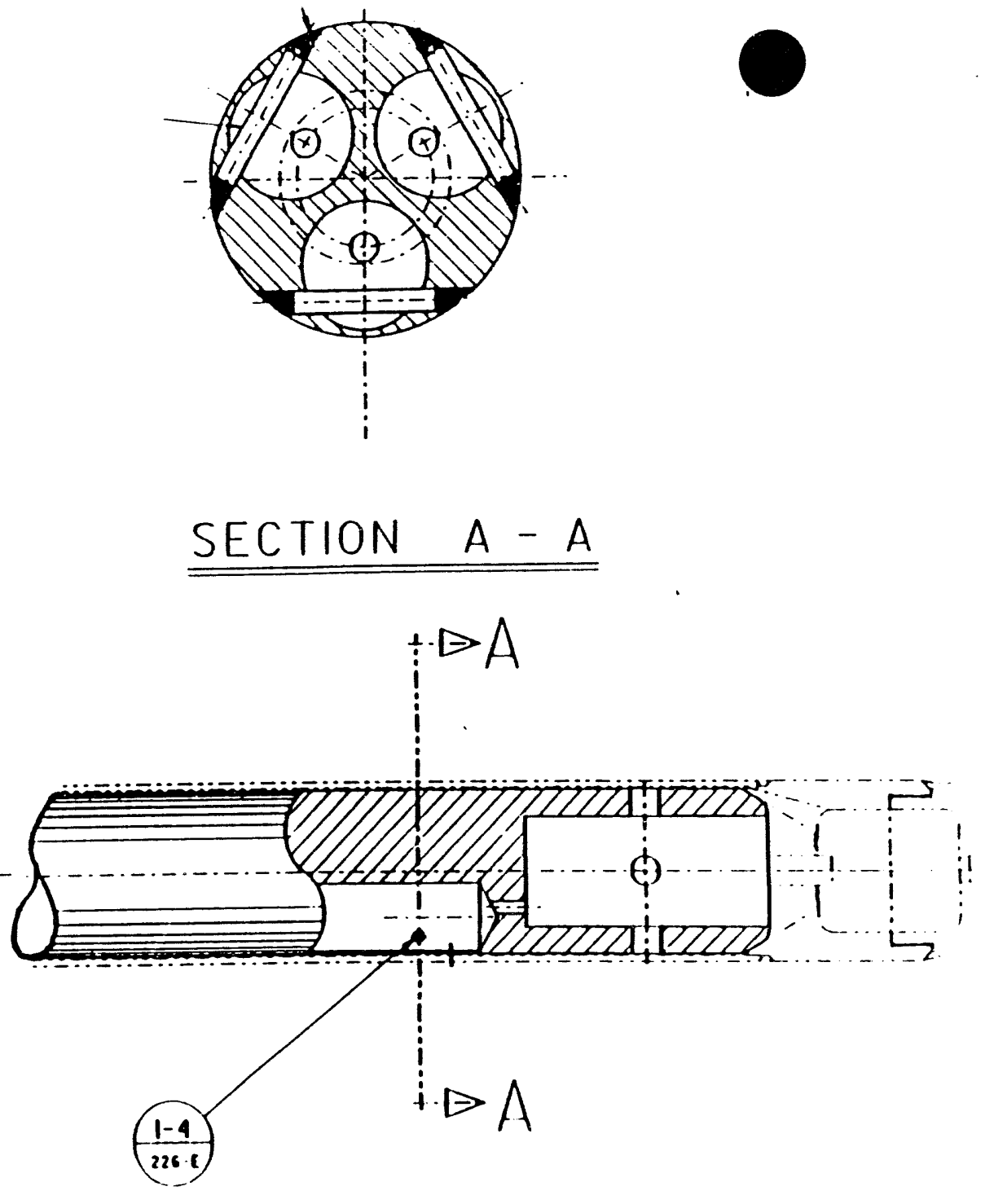

Fig 2. 3-HDiE Irrdium Tianjat Holder 
ชำ

$(\underline{2}+2)(1)$

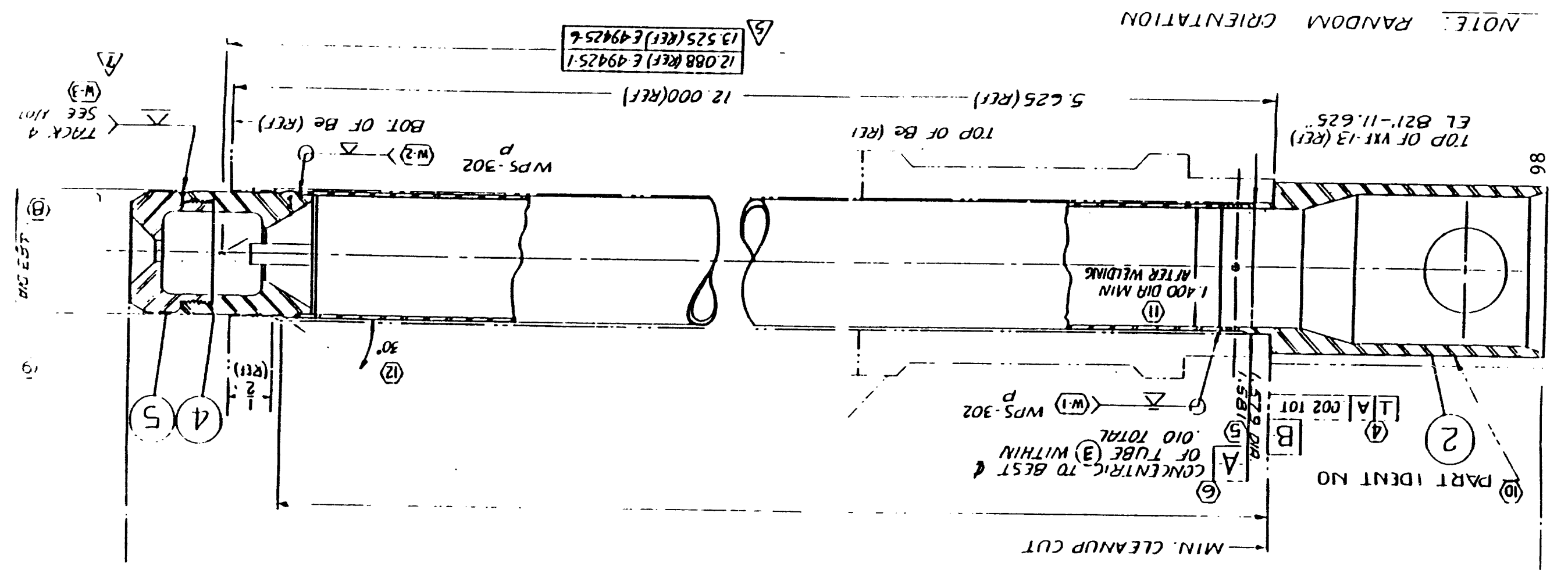




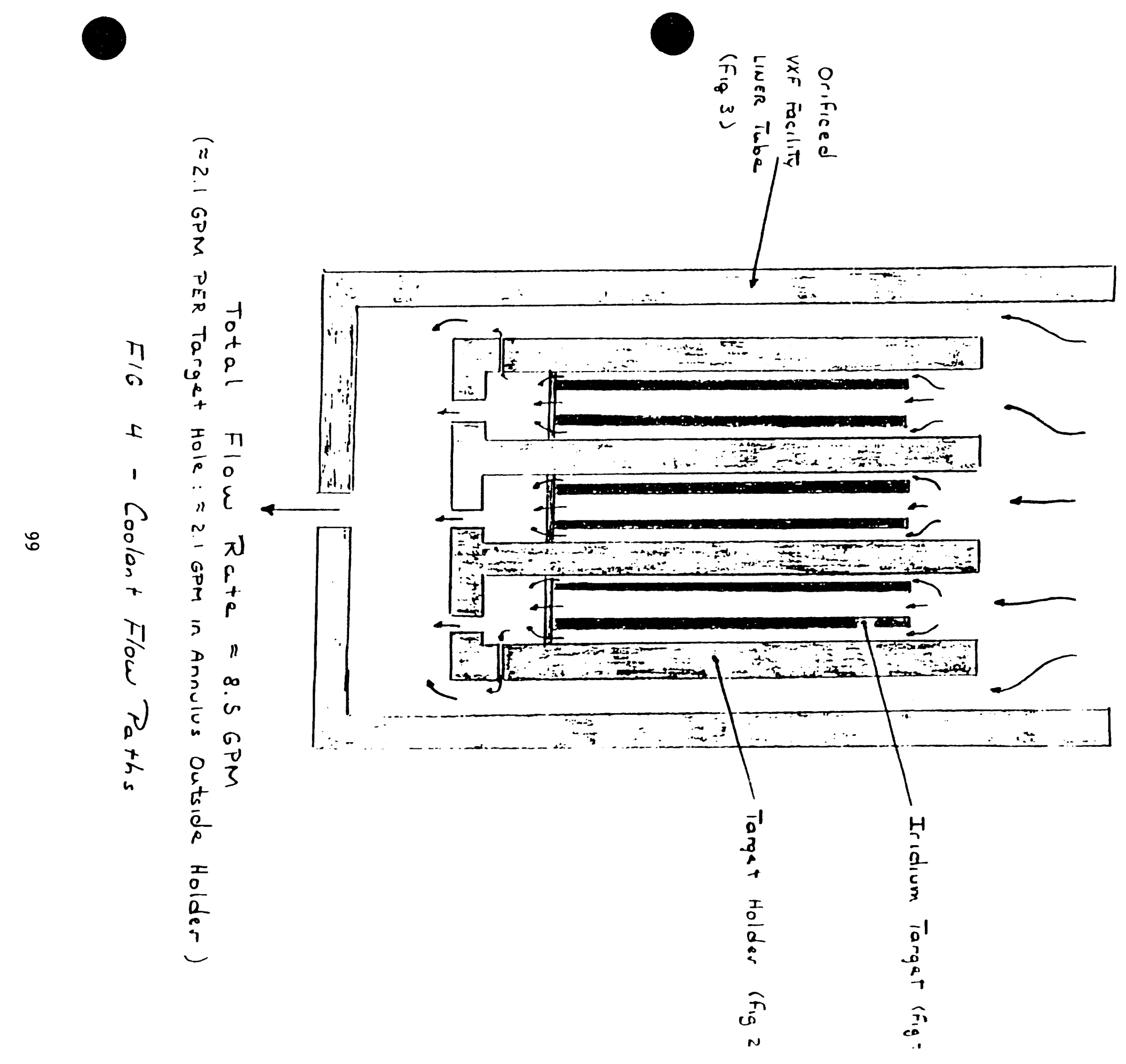


RESEARCH REACTORS DIVISION

NUCLEAR SAFETY ASSESSMENT CHECRIIST

(Attach Checklist Basis Form and Safety Assessment)

\begin{tabular}{|c|c|c|}
\hline $\begin{array}{l}\text { CHECCOIST APPLCABLE TO } \\
\text { ESA-HFIR-92-1 } \\
\text { TNEIL Iridium Target Iradiations in the SVXF }\end{array}$ & REV. & 0 \\
\hline PREPARED BY & \multicolumn{2}{|c|}{$4 / 14 / 92$} \\
\hline REVIEWED BY & DATE 4 & \\
\hline
\end{tabular}

\section{SAFETY ASSESSMENT - PART A}

(1) Is there an increase to the risk of accidents previously evaluated in the SAR?

YES_NO $X$

(2) Is there an increase to the risk of malfunction or failure of equipment important to safety previously evaluated in the SAR?

YES NO X

\section{SAFETY ASSESSMENT - PART B}

(3) Will the possibility of any accidents not previously considered in the SAR be created by this change? YES_NO_X

(4) May the possibility of malfunction or failure of equipment important to safety be created by this change (beyond what has previously been considered in the SAR)?

YES NO $X$

\section{SAFETY ASSESSMENT - PART C}

(5) Will this item require a change to the facility Technical Specifications: YES_NO $\mathrm{X}$

If the answer to the above is "YES", identify the specification(s) affected and/or attach the applicable pages with the change(s) indicated.

(6) Will the margin of safety as defined in the bases to the Technical Specifications be reduced? YES_NO $\mathrm{X}$

\section{UNREVIEWED SAFETY QUESTIONS}

\section{SAFETY ASSESSMENT - PART D}

(7) Are the sum of the risks in parts A and B judged to be acceptable?

YES $X$ NO

(8) Given the results of Parts A, B, and C, does this change constitute an unreviewed safety question?

YES_NO $\mathrm{X}$ 


\section{RESEARCH REACTORS DIVISION \\ NUCLEAR SAFETY ASSESSMENTT CHECKILIST BASIS \\ (Attachment to Nuclear Safety Assersment Chocklist)}

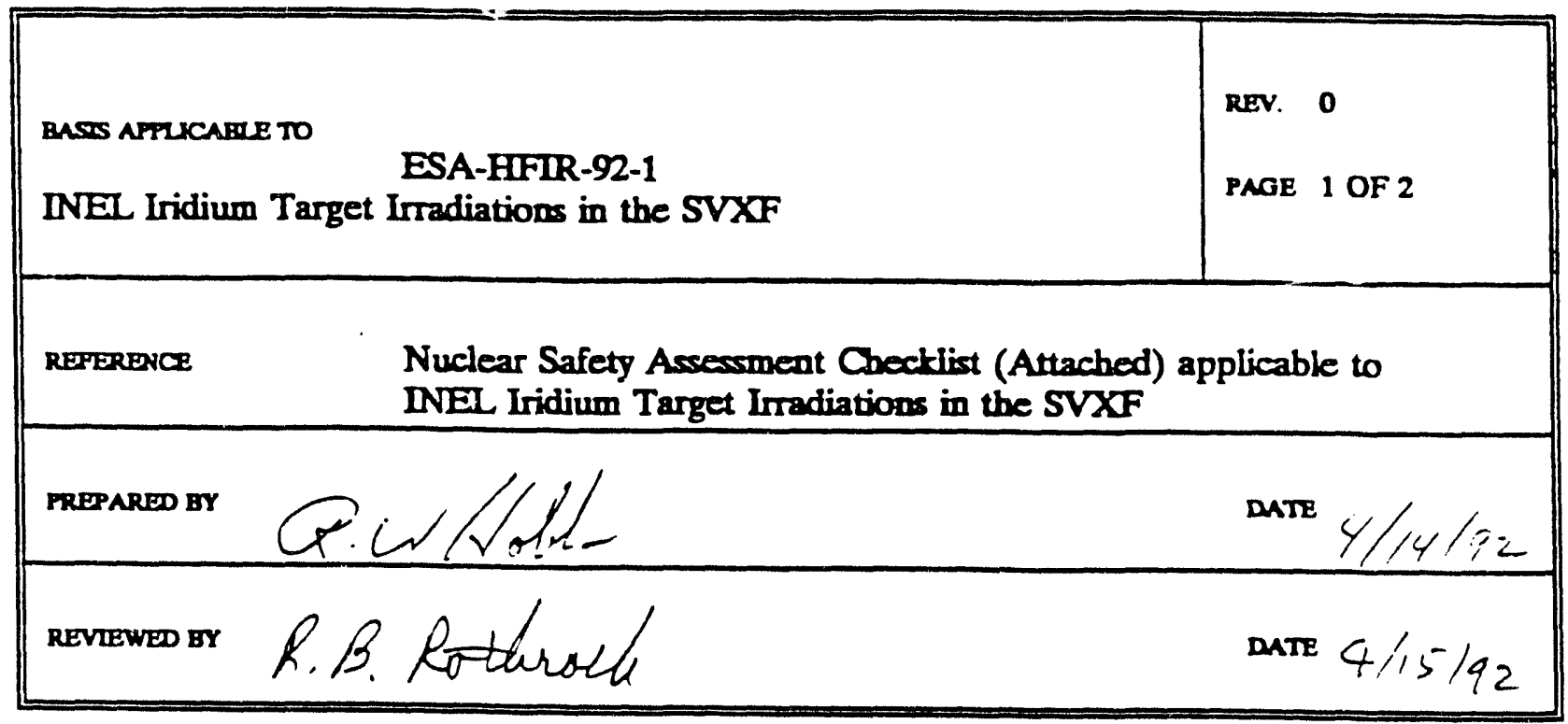

SAFETY ASSESSMENT - PART A (Continued)

(1) There is not an increase to the risk of accidents previously evaluated in the Safety Analysis Report (SAR).

As discussed in the ERS, the experiment is too far removed from the core to present any reactivity concerns and is more than adequately cooled. Thus normal irradiation of the iridium targets poses no risk to the reactor. The only envisioned failure mode of consequence is a rupture of the outer containment sleeve to the extent that a few of the iridium pellets could be released to the reactor coolant. As discussed in the ERS the potential for this failure is extremely low, the failure would not initiate a reactor accident and the most likely consequence would be that the released pellets are captured on the inlet coolant strainer. Thus there is not an increase in risk to accidents previously evaluated in the safety analyses report.

(2) There is not an increase to the risk of malfunction or failure of equipment important to safety previously evaluated in the SAR.

As discussed above, only failures of very low probability would release pellets into the reactor coolant. The most likely consequence of this remote failure would be capture of the pellets on the coolant inlet strainer or perbaps a crevice in the beat exchangers (i.e., they would not cause fuel element flow blockage). It is extremely unlikely that if a pellet were to be released from such a failure it would lodge in a control element mechanism in such a manner as to inhibit its motion and it is not considered credible that it would bind all four control elements. Since the SAR considers that one control element will fail to scram when required, and since the failure and probability that the failure would bind a control element is extremely unlikely, there is no increase in risk of failure of equipment important to safety.

RRAP 3242 


\section{SAFETY ASSESSMENT - PART B (Continued)}

(3) The possibility of any accidents not previously considered in the SAR will not be created by' this change.

As discussed in (1) and (2), in the unlikely event a target failure were to occur, this failure would not initiate a reactor accident.

(4) The possibility of malfunction or failure of equipment important to safety will not be created by this change (beyond what has previously been considered in the SAR).

See response (2).

\section{SAFETY ASSFSSMENT - PART C (Continued)}

(5) This item will not require a change to the facility technical specifications.

The condust of the experiment is in compliance with all HFIR Technical Specifications and their bases. See Table 1 of ERS-HIFIR-92-1.

(6) The margin of safety as defined in the bases to the technical specifications will not be reduced.

See response (5) above.

RRAP 3242 


\section{ATTACHMENT D}

\section{FABRICATION REQUIREMENTS FOR IRIDIUM IRRADIATION CAPSULES FABRICATED AT INEL AND IRRADLATED AT ORNL}

The requirements set forth herein apply to iridium irradiation capsules fabricated at Idaho National Engineering Laboratory (INEL) and provided to Oak Ridge National Laboratory (ORNL) for use in producticn of ${ }^{192} \mathrm{Ir}$. Such capsules may be fabricated specifically for ORNL or may be provided from groups of capsules fabricated for use at both INEL and ORNL.

The requirements are:

1. The capsules shall be fabricated in full compliance with the requirements specified by EG\&G Drawing Number 437576, original issue, titled ATR Outboard A and Inboard A\&H 16" Iridium Irradiation Capsule, except that the liquid penetrant inspection specified in Note 3 of the said drawing shall not be required.

2 The following additions requirements

a. INEL shall furnish a sample of each batch of aluminum material used in the subject fabrication process. The sample shall be labeled with the QA number customarily used by INEL to identify the batch. The sample will be tested by ORNL per RRD-MS-52, Section 4, to confirm the aluminum used in that batch of capsules conforms to the drawing requirements.

b. INEL shall ultrasonically clean the capsule parts in acetone for 5 minutes followed by 5 minutes of cleaning in isopropyl alcohol using standard ANC-STD-7008 as a guide. All bandling of the parts after cleaning should be done using clean cloth gloves.

c. Prior to closure welding the capsules, INEL shall radiograph the entire length of each capsule at 0 and 90 degrees per EG\&G Procedure 9.1 Appendix 1, to ensure the iridium pellets have been satisfactorily loaded. Copies of the radiographs shali be submitted to ORNL as part of the fabrication package (see 2.j. below).

d. INEL shall add a drying step to the fabrication process which is to be performed just prior to closure welding the subject capsules. The capsules shall be dried at a minimum of 220 degrees Celsius for a minimum of 15 minutes. The intent is to remove any residual organic volatiles remaining from the cleaning process.

e. Capsule welding shall be performed using INEL weld procedure specification A-2.0 and srtinent sections of the INEL Weld Manual. INEL affirms that these procedures meet the ASME requirements specified on the drawing. 


\section{FABRICATION REQUIREMENTS FOR IRIDIUM IRRADIATION CAPSULES}

FABRICATED AT INEL AND IRRADIATED AT ORNL

Page 2 of 2 pages

f. INEL shall perform a visual examination of each completed capsule according to EC:\&G Procedure CP9.6 Appendix 4.

g. INEL shall modify the Helium pressure test from the current nominal pressure of 500 psig to a minimum pressure of $700 \mathrm{psig}$, and shall perform the helium leak test in a manner acceptable to a quality inspector certified to approved EG\&G standards.

b. INEL shall label each capsule transferred to ORNL with a unique identifying number of the following pattern: OR-IR-011, OR-IR-012, ...OR-IR-XXX in sequence of delivery. NOTE: The first 10 capsules, which have already been submitted to ORNL but are unlabeled, will be labeled with the first 10 numbers in the sequence by ORNL

i. Any nonconformances or deviations from the approved requirements shall be submitted by INEL to ORNL for approval prior to implementation.

j. INEL shall provide a letter certifying conformance to the requirements for each group of targets fabricated, as well as a complete fabrication package documenting implementation of the requirements.

ACCEPTED FOR INEL

Date

Date

Date

\section{ACCEPTED FOR ORNL}

Date

S. E. Burnette, RRD

Date

R. W. Hobbs, RRD

Date

S. S. Hurt, RRD

Date

L. H. Simith, QD

C. L. Ottinger, CTD

Date 


\section{EXHIBIT D}

JUNE 10, 1993, MEMO R. W. HOBBS TO CRONE/FARRAR/WHALEY 


\section{Internal Correspondence}

June 10. 1993

R. A. Crone

M. B. Fartar

P. M. Whaley

Experiment Work End of Cycle 318

1. Scheduled in-ressel experiment configuration changes:

\section{Iarget}

\begin{tabular}{|lll|}
\hline Posirion & $\begin{array}{l}\text { Remove } \\
\text { No target work is } \\
\text { currently scheduled }\end{array}$ & Comments \\
\hline
\end{tabular}

Removahle Bervllium

$\begin{array}{llll}\frac{\text { Position }}{R B} 1 \mathrm{~B} & \frac{\text { Remove }}{\text { MFE200J }} & \frac{\text { Insert }}{\text { MFE 200J }} & \text { Comments } \\ \text { RB } S B & \text { MFE400J } & \text { MFE I00J } & \text { Index per Fig. 1 } \\ & & \text { Ref Procedures } \\ & & \text { OP } 5.1 \text { and } 5.2\end{array}$


R. A Crone

M. B. Farrar

P. M. Whatey

Page 2

June 10,1993

Permaneni Bervllium

\begin{tabular}{|c|c|c|c|}
\hline Pnsition & Remove & Insert & Comments \\
\hline \multirow[t]{2}{*}{$\overline{I X V X F .3}$} & $1 \cdot 1 \cdot 92 \cdot 12$ & $\overline{1.1 .92 .20}$ & See allached \\
\hline & IR.56, IR. 57 & IR.78, IR.79 & memorandum from \\
\hline \multirow[t]{2}{*}{ ISVXF.S } & $1-1-92-11$ & $1-1.92 \cdot 1.3$ & C. L. Orlinger. \\
\hline & LR.49. IR-50, IR-51 & IR-72, IR-73, IR-74 & dated June 10.1993 \\
\hline \multirow[t]{2}{*}{ ISLXF.9 } & $1 \cdot 1 \cdot 92 \cdot 16$ & $1 \cdot 1 \cdot 92.4$ & \\
\hline & IR 53, IR-54, IR-55 & IR-75, IR-76, IR-79 & \\
\hline
\end{tabular}

Pressure Vessel Surieillance Sites

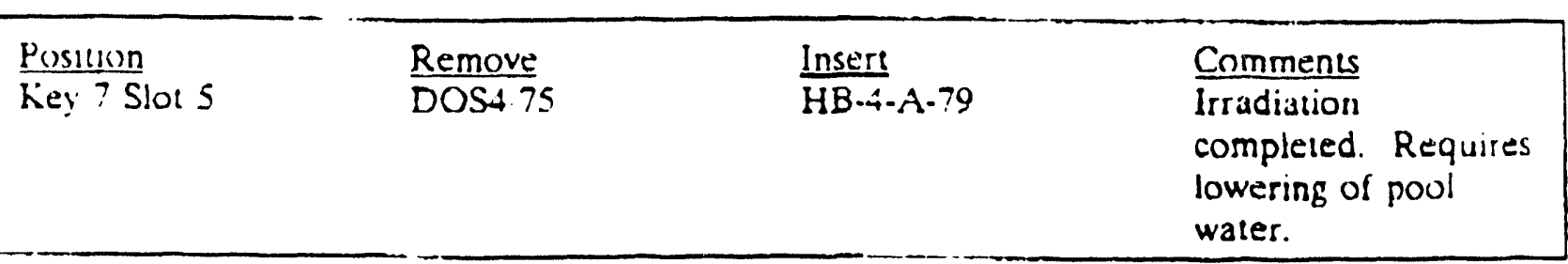

2. Experiment shipments

There are no scheduled palladium shipments.

3. Matenals Irradiation Facility

See autached list from R. L. Wallace.

4. Gamma irradiations

Metals and Ceramics Division (K Farsell and S. T. Mahmood) have requested that the gamma irradiation experiment be transferred trom the cold element to the hot fuel element as soon as convenient. A second capsule (currently under review) may be altached to this sample at this time. if approval is obtained. Record lime and date of uransfer in the reacior shift sunerisor's log book. 


\section{R. A. Crone \\ M. B. Farrar \\ P. M. Whaley}

Page 3

June 10.1993

5. Pneumatic Tube Facility Repair

Currently the EF-3 and VXF.7 pneumatic tubes are tagged out due to air leaks and problems with a conductivity probe. It is critical to the ACD experimenters that the leaks and conductivity probe be lixed during this outage.

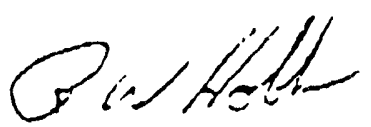

R. W. Hobbs, 7910, MS 6387 (4.8789)

RWH:pav

Altachuent

ce: C. W. Alexander

J. E. Bigclow

L. C. Emerson

H. A. Glovier

B. L Lepard

C. L Ottinger

R. B. Rothrock

R. L Senn

R. Wham

csiatt: S. E. Burnette

B. H. Cupp

R. D. Dabbs

T. L. Fancher

G. F. Flanagan

G. J. Hirtz

G. L Kickendahl

J. E. Lee

A. W. Longest

J. T. Parks

L. P. Pugh

R. R. Thoms

R. L. Wallace

RRD CARTS

RRD.DCC RC 


\section{EXHIBIT E}

AUGUST 24, 1993, MEMO C. L. OTTINGER TO K. E. McCORMACK 


\section{Internal Correspondence}

August 24, 1993

MARTIN MARIETA ENEROY BYBTEMS, IMC,

\section{K. E. McCormuck}

\section{Reyuest for Exception for ${ }^{102}$ Is Transfor}

The existing transportation plan for ${ }^{192}$ Ir targets from HFIR (Building 7910) 10 IFEL (Building 3525) specifies a minimum of five days between discharge from the reactor and iransfer. This limit was derived from the operations plan, which assumed that transter would be made only after startup of the folluwing HFIR cycle. Activity values for ${ }^{192}$ Ir were bused on conservatively high production istimates und on the assumption of flve days decay. Speciffcally, the caleulations were based on
75.000 curies of ${ }^{19}$ Ir.

Following the end of Cycle 321. eurrently projected for the eariy A.M. an September 4, there will be a 6-day shuldown, and it would be a distinet advantage 10 mak: one teansfer of ${ }^{192}$ Ir targets during the shuidown rather than waiting until restarl. The target mix on this oycle contains six targets that have nol had the full irradiation period, and, therefore, will not contain as much activity as regular targets. There are also two long-decay targets from Cycle 310. Collectively, these eight targets will contain approximately 62,000 curics of ${ }^{102}$ Ir and 7,000 curies of ${ }^{196} \mathrm{Is}_{\mathrm{s}}$ as of time of shipment, a cotal of 69,000 curicis compured to 75,000 curics covered in the plan. The thermal load will bs proportionatcly even lnwer because of the lower cnergy of the ing.

Approval for une 19.js transfer to be made not earlier than 72 hours after end of Cycle 321 is requested. If you approve, glease sign below. If you have questions please contact me at $4-6991$
(fax 4-6U08).
C?

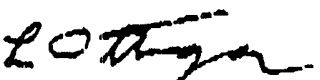
C. L. Otsinger, 4965B, MS.6385 (4.6991)

\section{CLO:jp}

a:: E. D. Collins

L. J. Galtuso

T.J. Hirt2

T. M. Kisney

Fil:

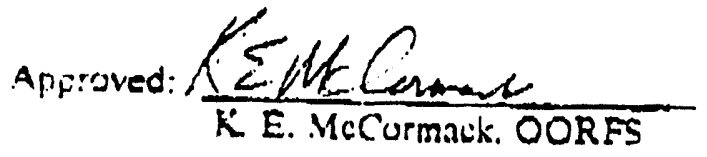

Date $8 / 24 / 53$ 
EXHIBIT F

NOTES ON CRITIQUE OF HIGH RADIATION IN REACTOR BAY 
Seprember 7, 1993

1855 hours

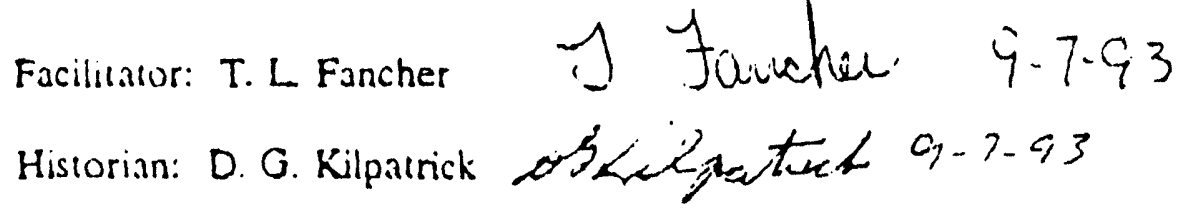

There were two jobs ongoing in the reactor bay at the time of the incident. One job involved I\&.C personnel calibrating hydraulic rabbit facility instruments. Persunnel involved in this job were Ken Hardin, Willis Russell, and Kurt Light.

The other job cunsisted of loading the HRLEL carrier on a truck for shipmen. There were four perscuunel in the rigging crew and one rigging supervisor, alnng with Lyn Clevenger, Ken Curtis, and Bob Scboenseld involved in this job.

Arcording to Clevenger, when the carrier was being lilled for Inading, his chirper alarm went off Immedialely after that, the reactor bay monitrons began alarining, followed by activation of the FR:IS alam.

Some personnel involved in the I\&.C job stated they knew they hadn't done anything to cause the alarm; Clevenger at first thought it was the crane alarm sounding.

The carner loading job had stasted at about 1720.

HP Ken Curtis stated that he had surveyed the carrier prinr to lifting. The ca rier sead $10 \mathrm{mrhr}$ on the sides and 30 mrme on the top.

HP Roger Ziegler staled the carrier had becn luaded with 8 inds last night when he had surveyed it. His readings were consistent with Curtis's reading and he further stated the carrier read $26 \mathrm{mr} / \mathrm{hr}$ on contact and $2 \mathrm{mr} / \mathrm{hr}$ at one fout from the bottom while lifting over the pool rail

The riggers had tilted the carticr to approxinately 30 degrees from vertical when persunnel chirpers started going off. It was approximately 2 leet off the reactor bay noor.

The southeast reactor bay mnnitron alarmed tirst, followed by the northwest reactor bay monitron.

Shrorly after this. the chirpers in the control rnom started alarming.

Schoenfeld diso stated that the inonitruns alarmed sequentially, then the FRMS alami actuated.

Zicigler stated that radiation !evels last nighe during the louding of the carrier with masinum reading of $3.5 \mathrm{R}, \mathrm{hr}$ was observed while pulling ruds into the carrier. After the dunt was closednatched.

hetore the top hat was installed on the carrier the dor Cluvenger statcil the event was "almost like something went critical in the cartice, or something hroke loose." 
Notes on Critique...

Page 2

The riggers stated after the alarm sounded the carricr was lowered until it was horizontally that on the reactor bay tluor.

Schoenteld did not leave the bay immediately upon the alarm sounding. He continued to survey around the carrier arca.

HP Mike Whillenbarger was in the shiti supervisor's oftice whon the FRMS alarm sounded. He went to the HP office to get a survey meter. Conaway already had obtained a meter from the control room and they both enterced the reactor bay. As they entered the reactor bay. Ken Curtis was directing personnel out of the bay. Consway se! the carrier upright on its end. The radiation levels decreased to approximately $5 \mathrm{R} / \mathrm{hr}$ at approximately 5 fiet from the carrier, south and cast of the carriter.

Whillenharger left and went to the primary heat exchanger cell entrance area and pertormid radiation surveys which were normal.

Schixenteld and Conaway were tho last ones out of the reactor bay (approximalely 3.5 minutes after the FRMS alurm souniled).

Upon returning trom the heat exchanger area. Whittentiager went to the stcond tloor and ran into Cunaway and Schoenteld who were Evacuating the building.

Whiltenbarger went to the control room where Clevenger was monitoring the FRMS pane!.

The carrier is presently resting with une corner on a $3 / 8 "$ diameter lifting sling.

In the inntrol room. Cleringer cleared the FRMS alarm modules, thercby stopping the evacuation signal. The FRMS recorder read as follows: point 6 , in "high" alarm, approximatcly $28 \mathrm{mr} / \mathrm{hr}$; point 7. in "iaution" alarm. approvimately $11 \mathrm{mr} / \mathrm{hr}$; all uther readings were normal.

Clevenger and Whiltenbarge: were the last unes to evacuate the control ronm, approximately $5 \cdot 10$ minutes atier the FRMS alurm had sounded.

Wike. Fartar made an all area PA announcement of the situation and activated the RRD Emergency Respunse Teim.

The procedure to load the carrier on the truck was being tollowed at the lime of the event.

1S: irchnician. Randy Welch. stated the alarm was not audible in the ISCC shop. The PA annuuncement clarified the situation. 


\section{EXHIBIT G}

\section{ALARA PLAN FOR CASK TRANSPORT}




\title{
ALARA PLAN
}

\section{UNLOADING AND INVESTIGATION OF ${ }^{192}$ IR FROM THE 6-1/2 INCH HRLEL CASK IN BUILDING 3047}

\author{
Prepared by \\ Chemical Technology Division
}

September 28, 1993

Submitted by:
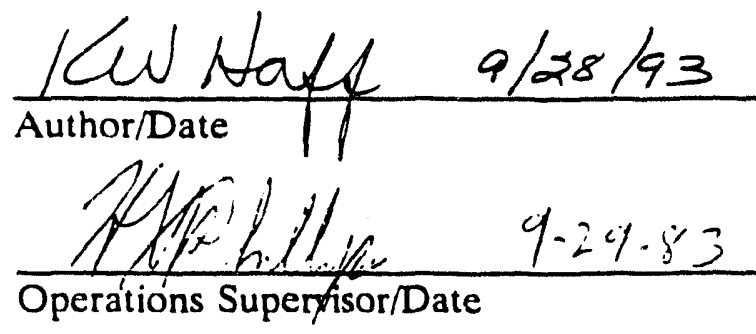

$\frac{k C \omega \text { Damey } / 9-2 q-93}{\text { Facility SupervisorDate }}$

Approved by:

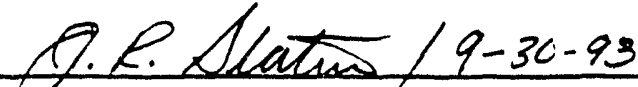

Rudiation Protection Area Supervisor/Date

$\frac{\text { Hisetaw } 9-30-93}{\text { ORNL ALARA Coordinator/Date }}$

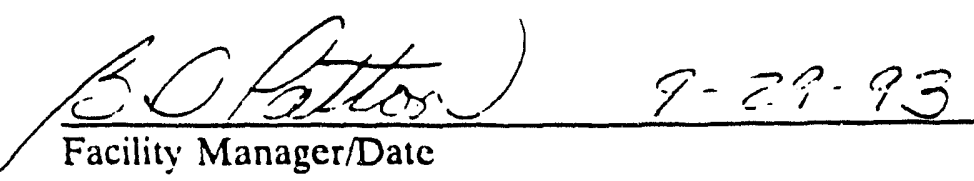

$\frac{\text { Phipenumg } 9-30-93}{\text { Division Director/Date }}$




\section{ALARA PLAN FOR UNLOADING AND INVESTIGATION OF ${ }^{192}$ IR FROM THE 6-1/2 INCH HRLEL CASK IN BUILDING 3047}

\section{INTRODUCTION}

The Chemical Technology Division (CTD) of Oak Ridge National Laboratory (ORNL) plans to receive the 6-1/2 inch HRLEL Cask containing seven (7) ${ }^{192} \mathrm{Ir}$ targets in its Radioisotopes Development Laboratory, Building 3047, from the High Flux Isotope Reactor (HFIR) to remove the apparently damaged ${ }^{192}$ Ir target(s) from the cask, perform an initial inspection of the targets . and transload the targets for transfer to HRLEL. The seven (7) targets contain a total of approximately 45,000 curies of ${ }^{192}$ Ir. This plan is prepared in accordance with Health Physics Procedure Number 6.2, Rev. 2, Personnel Exposure Control.

\section{2}

\section{PROCEDURE}

The detailed procedure for this operation is described in procedure RDP-740, Building 3047 HRLEL Cask Unloading Procedure, and includes the following major operations:

2.1 receipt of the cask at Building 3047.

2.2 transfer of the cask into the cell at Building 3047 .

2.3 removal of the top plug of the cask.

2.4 removal of the ${ }^{192}$ Ir-containing basket from the cask.

2.5 preliminary inspection of the basket and ${ }^{192} \mathrm{Ir}$ rods contained in it. and

2.6 transfer of the ${ }^{192}$ Ir rods and basket to a cask for transfer to Building 3525 for final examination, unloading, and disposal.

\section{RADICLOGICAL CONSIDERATIONS}

\subsection{Previous Experience}

There has been no explicit previous experience with this particular case in Building 3047, e.g. a situation in which a ruptured ${ }^{192}$ Ir target was recovered from a cask. However, many similar situations of recovery-for-processing of not-ruptured ${ }^{192}$ Ir and europium targets have been conducted. Previous ${ }^{192}$ Ir operations performed in the facility have been conducted witncut mishap or excessive radiation exposurc to operating personnel. Other similar operations to this include handling of ${ }^{90} \mathrm{Sr}$ and ${ }^{137} \mathrm{Cs}$ Waste Encapsulatiun Storage Facility (WESF) capsules containing up to 90.000 and $47,000 \mathrm{Ci}$ of material respectively. These operations are comparable in expected radiation complexity and can be used as examples to predict expected radiation dose rates in the operating area of the Building 3047 cells. 


\section{$3.2 \quad$ Source}

The source is a basket containing seven (7) irradiated iridium rods containing approximately $45,000 \mathrm{Ci}^{192} \mathrm{Ir}$. At least one of the rods is believed to be ruptured and has apparently released some of its contained material into the transfer cask. The cask is poorly designed for containment of radioactive material and has apparently released some of this material outside.

\subsection{Cask Shielding}

Nominal cask shielding is approximately eight (8) inches of lead and, for normal transfer operations, is more than adequate. This has been demonstrated by many such transfers of this material in this cask. A special lead shielded (3-1/2 in. thick) "shield pan" has been designed, built, and attached to the bottom of the cask to prevent additional material from escaping from the cask and to shield that which is already present. This "shield pan" weighs approximately 1440 pounds and is attached to the bottom of the cask with chains. Additional lead shielding has been added to the sides and lip of the "shield pan" to prevent streaming and radiation leakage. There is no guarantee that additional material will not escape from the ruptured target rod and find its way down into the bottom of the cask and shield pan in handling operations in the transport of the cask to Building 3047.

Calculations indicate that the 3-1/2 inches of lead shielding in the pan will protect from excessive radiation exposure from the bottom of the pan in the event of loss of the entire $45,000 \mathrm{Ci}$ of material in the rods. Radiation readings are expected to be approximately $100 \mathrm{mrem} / \mathrm{h}$ at one meter from the bottom of the cask in this situation. Calculations also indicate that streaming of radiation from a crack between the bottom of the cask and the pan which could open during lifting operations is a matter for additional consideration, bowever. The radiation must escape through a torturous path, i.e. a very small crack estimated not to exceed 0.010 in. thick, and the equivalent of approximately $1 / 2$-inch of lead shielding exists at this crack. This is an area of special concern during the transportation phase of this operation and during the initial operations of off-loading the cask and transferring it to the hot cell in Building 3047. Calculations indicate that the radiation readings during this situation could reach $1 \mathrm{rem} / \mathrm{h}$ at one meter from the cask. Special precautions and radiation protection measures have been taken to avoid exposure from this potential source. Special precautions have also been taken in accident avoidance and for prevention of release of material and can be found in the transportation plan for this movement. The radiation protection measures include:

3.3.1 precautionary inspections and tightening, as required, of the chains holding the "shield pan" to the bottom of the cask after each movement or lift of the cask.

3.3.2 movement of the cask on a Sunday morning when the ORNL population is at a minimum, 
3.3.3 a precautionary sweep of the roads over which the cask will travel to ascertain that personnel are not in or along the path of the transport vehicle,

3.3.4 inclusion of three (3) Radiation Protection (RP) personnel with radiation detection instruments in the lead vehicle, the transport vehicle, and the following escort vehicle when the cask is moved,

3.3.5 alarming dosimetry, in addition to self reading dosimeters and TLD badges, will be worn by all personnel involved with the movement of the cask,

3.3.6 radiation detection instruments will be emplaced on the vehicle bed which can be read with binoculars during the transport operations,

3.3.7 personnel will be instructed to avoid contact with and the remain as far away from the cask as possible in all transfer operations and to be especially mindful of the potential for streaming from the crack at the base of the cask,

3.3.8 emplacement of temporary lead shielding on the transport vehicles which could be used in the event necessary,

3.3.9 other measures may be taken as deemed necessary by RP personnel at the time of movement, including addition of additional portable shielding, etc., and

3.3.10 the ORNL Emergency Operations Center (ORNL-EOC) will be operational during the movement, unloading from the transport vehicle, and emplacement of the cask into the hot cell in Building 3047.

\subsection{Cell Shielding}

The Building 3047 cell has nominal shielding of 3-ft of barytes concrete and is capable of handling much more material than proposed for this operation. The cell does have an in-cell telescope for examination of materials. The exposure through this telescope opening is expected to be approximately $10 \mathrm{mrem} / \mathrm{h}$ with a working level dose of approximately $1 \mathrm{mrem} / \mathrm{h}$ with the source in the normal working position. However, during periods in which the source is moved about the cell, especially when being unloaded from the cask and when being loaded into another cask for transfer to Building 3525, the radiation dose could exceed 50 $\mathrm{mrem} / \mathrm{h}$ at the telescope opening and $5 \mathrm{mrem} / \mathrm{h}$ in the working area. The radiation readings from the telescope opening are above head level and to the right of the cell window. We believe the expected dose rates are manageable and will not pose a problem to working personnel. Unnecessary personnel will be prohibited from the working area during the movement of the source in the cell and all operations will be continuously monitored by RP personnel. The area will be posted as a radiation area if determined necessary by $R P$ personnel. Visitors will be limited to those times when the source is in the cask or on the ccll tray. 


\subsection{Expected Dose Rates}

\subsubsection{Initial Off-Loading and Transfer Into Hot Cell}

Estimated time for operations: 4 hours

Estimated maximum dose rate in working area: $100 \mathrm{mrem} / \mathrm{h}^{1}$

Maximum dose to a single individual as a result of this operation: $40 \mathrm{mrem}$

Total personnel involved in the operation:

CTD, RP, and P\&E personnel:

Visitor (DOE and DOE Contractor):

$\frac{20^{2}}{4}$

Maximum dose expected to visitor personnel:

4 mrem

Average dose expected to CTD, RP, and P\&E personnel:

$10 \mathrm{mrem}$

Total dose to all personnel:

216 mrem

\subsubsection{Initial Examination of Source}

Estimated time for operations:

16 hours

Estimated maximum dose rate in working area:

$1 \mathrm{mrem} / \mathrm{h}$

Maximum dose to an individual as a result of this operation: $10 \mathrm{mrem}$

Total personnel involved in the operation:

CTD and RP personnel:

Visitor (DOE and DOE Contractor):

$\frac{10^{3}}{10}$

Maximum dose expected to visitor personnel:

4 mrem

Average dose expected to CTD and RP personnel:

8 mrem

Total dose to all personnel:

$\underline{120 \mathrm{mrem}}$

1 Maximum dose rate to individual is expected to be encountered inside the Building 3047 Cell.

2 Includes four (4) RP personnel and five (5) P\&E personnel.

3 Includes four (4) RP personnel. 
3.5.3 Transfer of Source to Cask for Transport to Building 3525

Estimated time for operations: 4 hours

Estimated maximum dose rate in working area: $100 \mathrm{mrem} / \mathrm{h}^{1}$

Maximum dose to an individual as a result of this operation: $10 \mathrm{mrem}$

Total personnel involved in the operation:

CTD and RP personnel:

Visitor (DOE and DOE Contractor):

$\frac{10}{2}$

Maximum dose expected to visitor personnel:

4 mrem

Average dose expected to CTD personnel:

8 mrem

Total dose to all personnel:

$\underline{88 \mathrm{mrem}}$

\section{ALARA CONSIDERATIONS AND RECOMMENDATIONS}

4.1 Time, Distance, and Shielding Considerations

Because hot cell operations are operations in which only trained, experienced workers can be used, there appears little which can be done to reduce the number of the CTD work force in the area below the stated levels. However, visitors can and must be limited. The following restrictions and requirements will be enforced:

4.1.1 A pre-operational briefing will be conducted each day before beginning any operations in this recovery operation.

4.1.2 All personnel, including visitors, will wear appropriate dosimetry including TLD and a self-reading dosimeter.

4.1.3 All personnel will spend only the minimum time necessary in the vicinity of the cask to complete work assignments.

4.1.4 RP personnel will be posted at the entrance to the area and will check all visitors during the initial phases of the work. This post will be eliminated at the discretion and agreement of the facility supervisor, facility manager, and the RP Area Supervisor.

4.1.5 All unnecessary personnel will be prohibited from the area during the cask unloading of the cask from the transport vehicle and loading it into the hot cell in Building 3047. 
4.1.6 One CTD person will be posted at the work site at Building 3047 with a radio to inform the EOC of conditions and work progress during unloading of the cask from the transport vehicle and loading it into the hot cell in Building 3047. The area will be cleared of all non-essential personnel except the Building 3047 work force, P\&E personnel, and RP personnel.

4.1.7 RP personnel will monitor visitor dose accumulation and keep the facility supervisor and facility manager informed. If dose exceeds the guidelines stated in this plan additional protective measures will be invoked to limit visitor personnel access to the area.

4.1.8 In no case will operations personnel dose accumulation be allowed to exceed the ORNL ALARA guidelines under normal circumstances.

4.1.9 All personnel will be advised of the potential for streaming from the bottom of the cask in the pre-operational briefing and advised to remain as far away from the cask as performing their duties will permit. Special emphasis will be placed on remaining above or away from the bottom section of the cask.

4.2 Contamination Considerations

There does not appear to be a contamination control problem associated with transfer and handling of this cask for the operations described here. Recovery of the cask is anticipated to be an operation consistent with usual operations in the Building 3047 hot cells and are therefore not discussed here. The contamination of the cask will be assessed in accordance with the procedure referenced in Section 2 of this plan and requirements in the Transportation Plan for this movement. Should any unexpected contamination occur during transport and/or unloading and emplacement into the hot cell, the situation will be assessed by the facility supervisor, the facility manager, and RP personnel and appropriate actions taken as required. Unnecessary visitor personnel are prohibited from being in the area during these operations.

4.3 ALARA Dose Goals

ALARA dose goals are set as stated in Section 3.5 of this plan. RP personnel will monitor visitor dose accumulation and keep the facility supervisor and facility manager informed. If dose exceeds the guidelines stated in this plan additional protective measures will be invoked to limit visitor personnel access to the area.

In no case will operations personnel dose accumulation be allowed to exceed the ORNL ALARA guidelines under expected circumstances. Should an unexpected situation arise, exceeding ORNL ALARA guidelines will be exceeded only after appropriate approval is obtained. 
4.4 Records and Followup

Records of dose rates measured during these operations, along with related information such as distance from the cask, distance from the cell wall, position of the source, etc., and job conditions, will be recorded during the operations. Dose results from self-reading dosimeters, together with related information, will also be recorded at various points of interest during the operation. A followup meeting will be held with the principal workers, the attending RP personnel, and other interested parties to record any observations or further information of radiological interest. These observations will be a permanent record of the facility in which the work took place.

\section{REFERENCES}

5.1 Health Physics Procedure Number 3.1, Rev. 2, September 3, 1993, Radiation Protection Standards

5.2 Health Physics Procedure Number 6.1, Rev. 1, November 15, 1990, ALARA Radiation Protection Program

5.3 Health Physics Procedure Number 6.2, Rev. 2, November 5, 1990, Personnel Exposure Control 


\section{EXHIBIT H}

PRESENTATION ON CASK TRANSPORT 


\section{Transport of 6 1/2" HRLEL Cask on October 3, 1993}

Dry Run Presentation

September 28, 1993
7910 Conference Room

D. M. McGinty 


\title{
-
}

\section{Objectives of Cask Transfer}

\author{
1. Safety of Personnel
}

2. Protection of Environment

3. Transfer of Cask into Hot Cell at 3047 


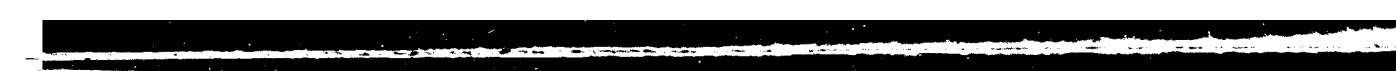

\section{Safety and Transfer Requirements}

1. Approval Transportation Plan

2. Approval Tie-down Plan

3. Personnel briefed on Requirements (Review Transportation Plan) 


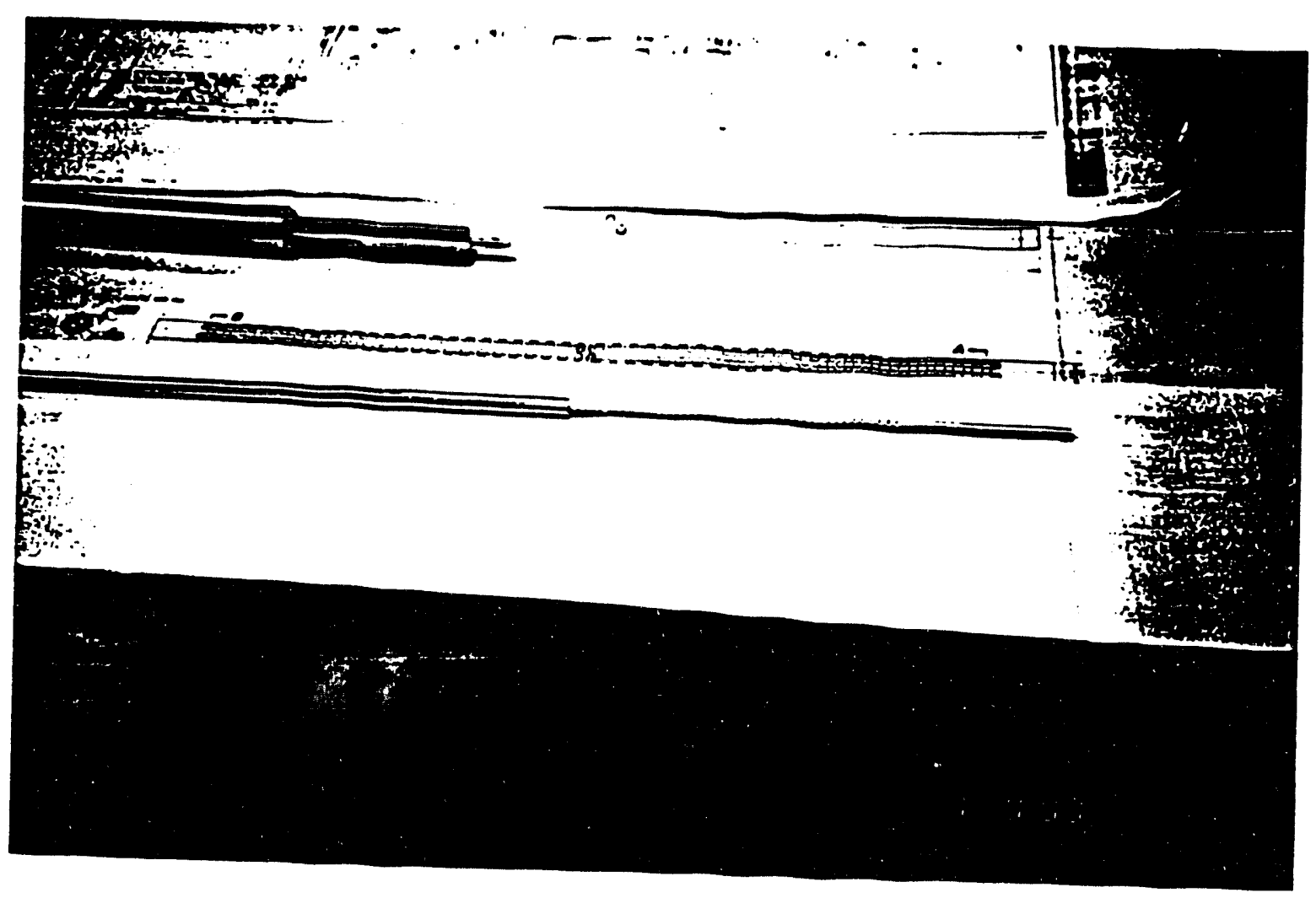




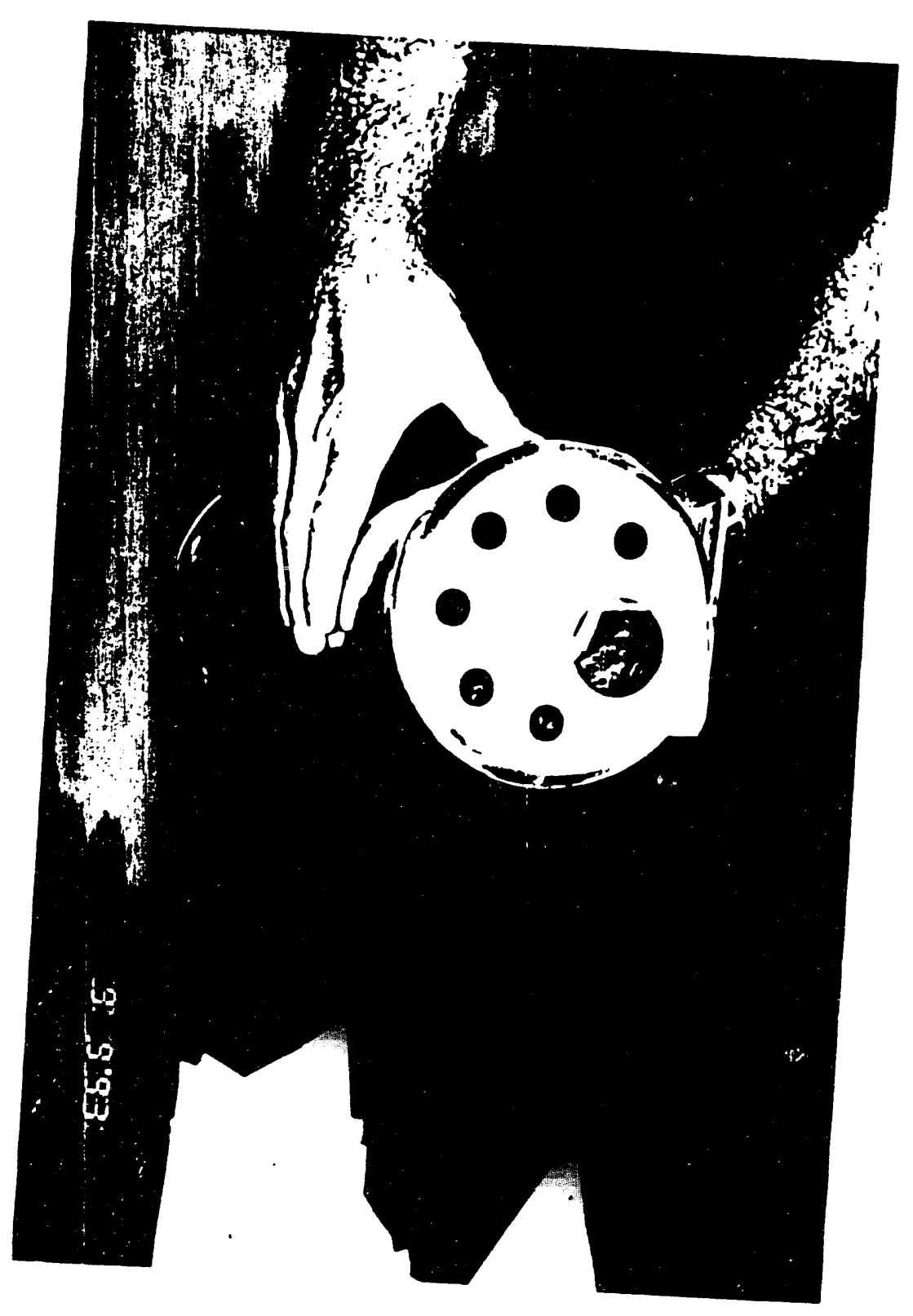




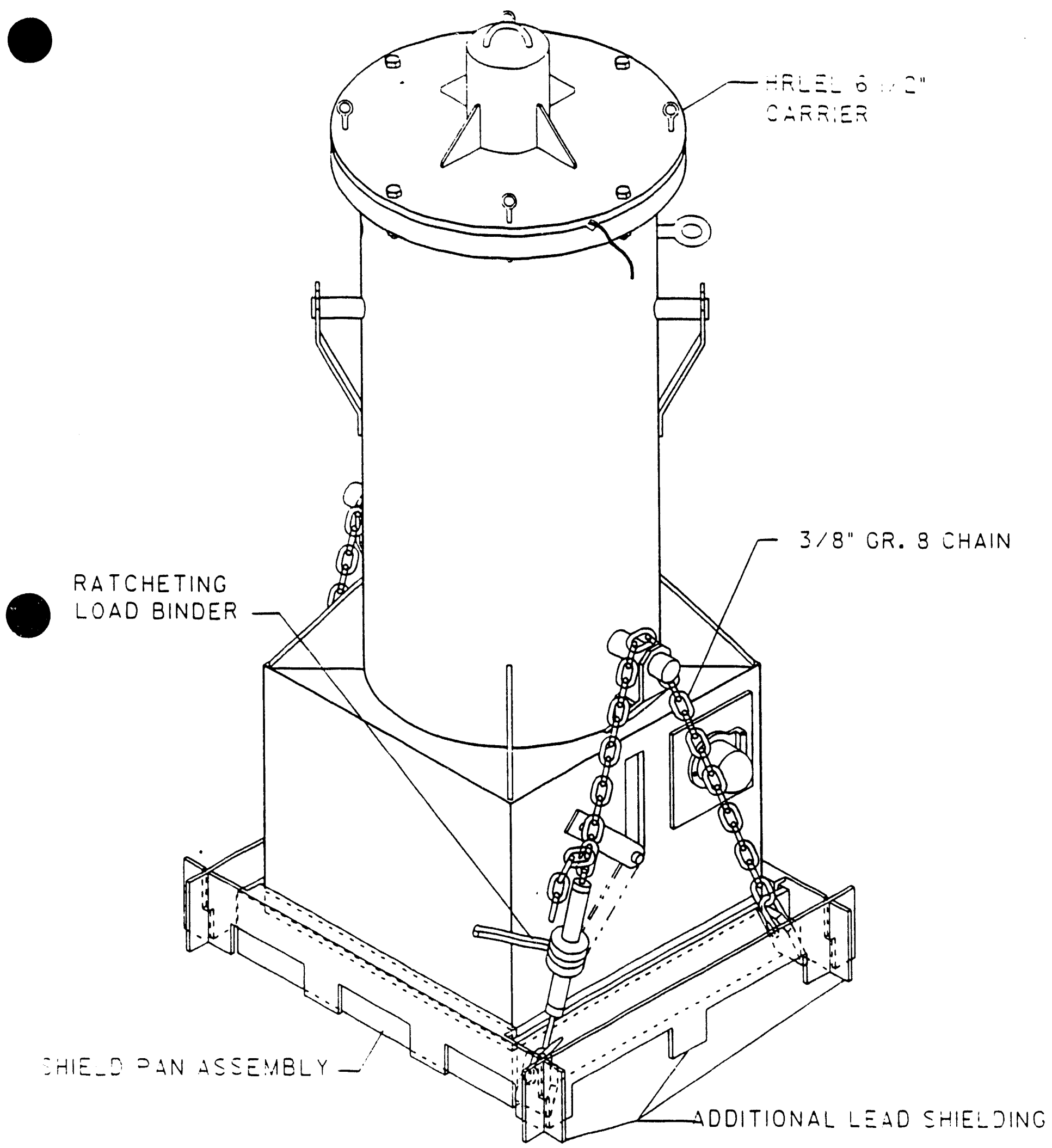

SHIELD PAN INSTALLATION 
Ir-192 Target Recovery, Transportation Schedule

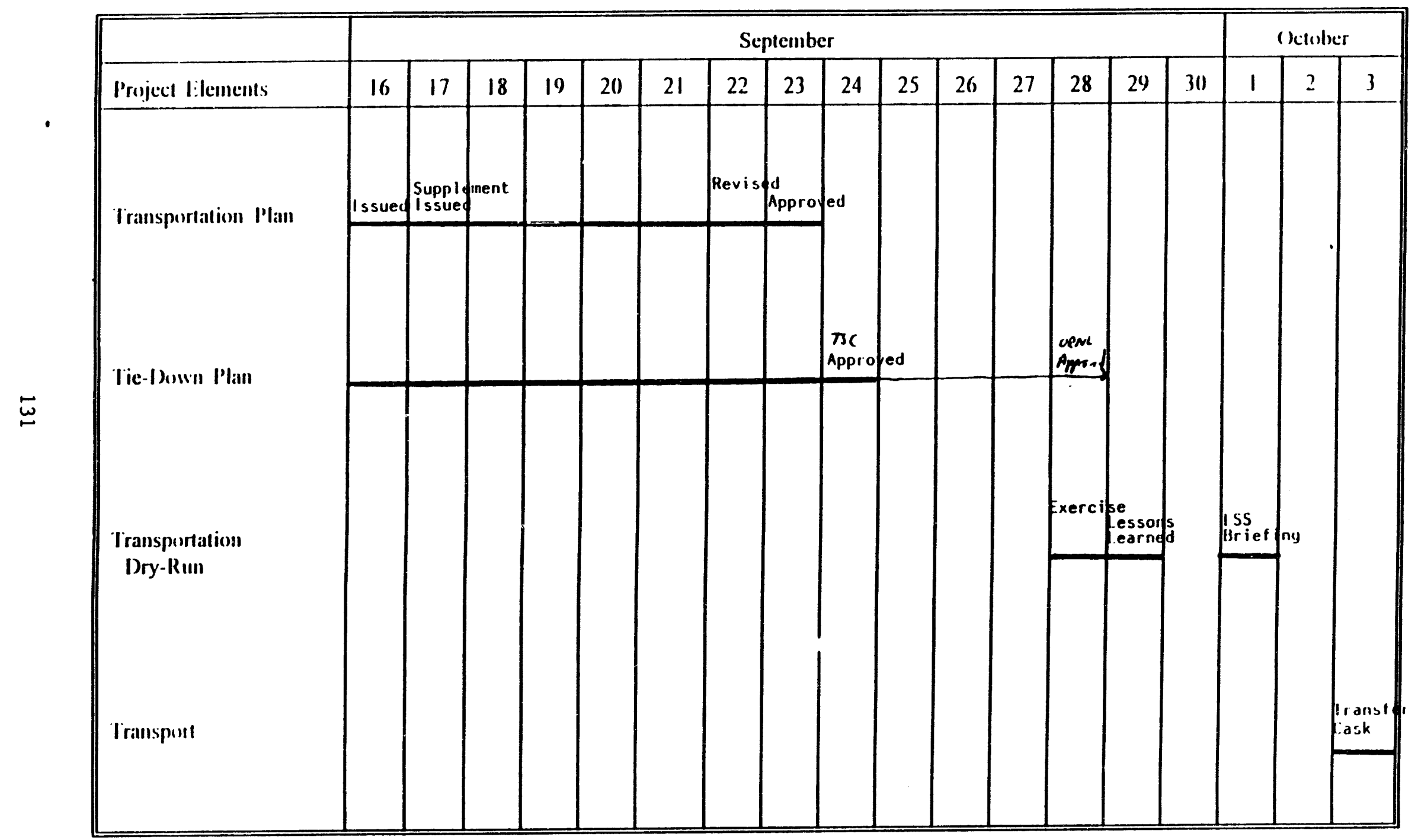




\begin{tabular}{|c|c|c|}
\hline \multicolumn{3}{|c|}{ Checksheet* for Transportation from HFIR to Building 3047} \\
\hline No. & Item & Initial: Date \\
\hline \multicolumn{3}{|c|}{ PRESHIPMIENT } \\
\hline 1. & $\begin{array}{l}\text { The pan is securely attached to the bottom of the cask per } \\
\text { recommendation of Transportation Safety Committee. }\end{array}$ & \\
\hline 2. & A latex seal has been applied to the pan and cask. & \\
\hline 3. & $\begin{array}{l}\text { The trailer being used for this transfer is a tandem-axle. } \\
\text { dropdeck type trailer. tag no. } 82939 \text {. }\end{array}$ & \\
\hline 4 & The vehicle inspection record has been verified to be current. & \\
\hline 5 & $\begin{array}{l}\text { A shielding block has been secured to the transfer trailer in } \\
\text { front of the closure opening on the bottom of the cask. }\end{array}$ & \\
\hline 6. & $\begin{array}{l}\text { Scheduling has been completed for loading and transfer } \\
\text { operations at HFIR and unloading at Building } 3047 \text {. }\end{array}$ & \\
\hline$i$ & $\begin{array}{l}\text { The transpor vehicle and trailer successfully passed a safety } \\
\text { lane inspection. }\end{array}$ & \\
\hline 8. & $\begin{array}{l}\text { Shipping papers have been initiated and instructions provided to } \\
\text { the HFIR shift supervisor based on communications with CTD } \\
\text { and M\&C. }\end{array}$ & \\
\hline 9. & $\begin{array}{l}\text { Sealant tape has been applied to closure paths on the locking } \\
\text { devices and the closure cylinder on the bottom section of the } \\
\text { cask. }\end{array}$ & \\
\hline 10. & $\begin{array}{l}\text { Sealant tape has been applied to the matting surface of the top } \\
\text { hat. }\end{array}$ & \\
\hline 11. & $\begin{array}{l}\text { Radiation and contamination checks are performed prior to } \\
\text { loading cask on trailer. }\end{array}$ & \\
\hline 12. & An approved and properly signed Tie-Down Plan is in place. & \\
\hline 13 & $\begin{array}{l}\text { The closure opening at the bottom of the cask has been } \\
\text { positioned towards the rear of the vehicle. }\end{array}$ & \\
\hline 14. & $\begin{array}{l}\text { The tie-down of the cask to the trailer has been completed per } \\
\text { approved plan. }\end{array}$ & \\
\hline 15 & $\begin{array}{l}\text { Detailed radiation and contaminatior. surveys have been } \\
\text { completed after loading cask onto trailer. }\end{array}$ & \\
\hline
\end{tabular}

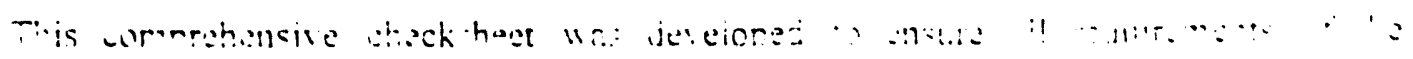
iransporation pian are satisried. 


\begin{tabular}{|c|c|c|}
\hline \multicolumn{3}{|c|}{ Checksheet* for Transportation from HFIR to Building 3047} \\
\hline No. & Item & Initial/Date \\
\hline 16. & $\begin{array}{l}\text { The tie-down of the cask has been inspected and approved by } \\
\text { QE\&I. }\end{array}$ & \\
\hline 17. & Vehicleicask labels and placecards have been properly prepared. & \\
\hline 18. & $\begin{array}{l}\text { Memoranda are used to transmit schedules, target designations. } \\
\text { quantities. and other required information from M\&C and/or } \\
\text { CTD to the RRD transportation coordinator and from the } \\
\text { transportation coordinator to the HFIR shift supervisor. }\end{array}$ & \\
\hline 19. & $\begin{array}{l}\text { A dry-run of transfer evolution has been conducted with the } \\
\text { principle parties. }\end{array}$ & \\
\hline \multicolumn{3}{|c|}{ DAY OF SHIPMENT PRIOR TO TRANSFER } \\
\hline 20. & $\begin{array}{l}\text { Complete a detailed radiation and contamination survey of the } \\
\text { cask. }\end{array}$ & \\
\hline 21. & The container has been wrapped in plastic material. & \\
\hline 22. & $\begin{array}{l}\text { Results of the above surveys have been given to all personnel } \\
\text { who will accompany the cask on its route to the hot cell. }\end{array}$ & \\
\hline 23. & $\begin{array}{l}\text { All personnel in the transport vehicle and escort vehicles have } \\
\text { been provided with self-alarming dosimeters for use during this } \\
\text { transport. }\end{array}$ & \\
\hline 24. & The driver has been verified to be DOT qualified. & \\
\hline 25. & $\begin{array}{l}\text { The trailer has a minimum of two radiation detectors set at } \\
\text { approximately the boundary of the trailer that can be read with } \\
\text { binoculars from the following escort vehicle. }\end{array}$ & \\
\hline 26. & $\begin{array}{l}\text { All personnel who are accompanying the escort vehicles and the } \\
\text { truck driver will be briefed in emergency response requirements } \\
\text { outlined in section } 6.10 \text { of the transporation plan. }\end{array}$ & \\
\hline 27. & $\begin{array}{l}\text { A security survey of the route and blocking of unsecured roads } \\
\text { has been completed. Nonessential personnel have been } \\
\text { evacuated. }\end{array}$ & \\
\hline 28. & The cask will only be shipped when weather is dry. & \\
\hline 29. & $\begin{array}{l}\text { The emergency operations Center (EOC) will be staffed during } \\
\text { this event to provide rapid emergency response if needed. }\end{array}$ & \\
\hline
\end{tabular}

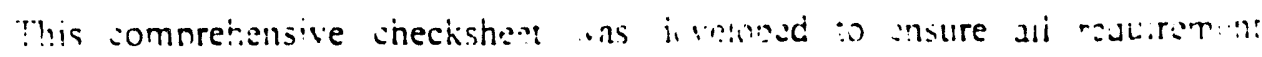
transportation ptan are satistied.
} 


\begin{tabular}{|c|c|c|}
\hline \multicolumn{3}{|c|}{ Checksheet $^{\star}$ for Transportation from HFIR to Building $30 \$ 7$} \\
\hline No. & liem & Initial/Date \\
\hline \multicolumn{3}{|c|}{ DURING SHIPMIENT } \\
\hline 30. & $\begin{array}{l}\text { This transfer is being made only between } 6: 00 \text { p.m. and dark on } \\
\text { normal work days/or on Saturday or Sunday based on prior } \\
\text { notice to and approval by the Laboratory shift supervisor and } \\
\text { Transportation Operations Management. }\end{array}$ & \\
\hline & Day/time of shipment (see note) & \\
\hline 31. & $\begin{array}{l}\text { The transport vehicle and trailer will be maintained in the } \\
\text { middle of the road to minimize the effects of any potholes or } \\
\text { breaks in the road surface. }\end{array}$ & \\
\hline 32. & Speed will be limited to 10 miles per hour at all times. & \\
\hline 33. & $\begin{array}{l}\text { The RRD supervisor-in-charge will escort the transter in a } \\
\text { separate leading vehicle equipped with two-way communication } \\
\text { with the transport vehicle. }\end{array}$ & \\
\hline 34. & $\begin{array}{l}\text { The RPT representatives will accompany the transfer. in the } \\
\text { lead vehicle. the transport vehicle and in the following escort } \\
\text { vehicle. }\end{array}$ & \\
\hline 35 & $\begin{array}{l}\text { Maintain approximately } 100 \text { feet separation distance between } \\
\text { vehicles. At each schedule stop. RP will check the radiation } \\
\text { readings on the survey. }\end{array}$ & \\
\hline
\end{tabular}

Vote: The evolution will be completed on Sunday moming in order to minimize evaucation efforts for unnecessary personnel if an accident occurs during the transport of this material.

This comprehensive checksheet was developed to ensure all requirements of the

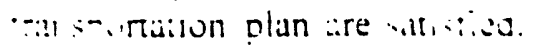




\begin{tabular}{|c|c|c|}
\hline \multicolumn{3}{|c|}{ Checksheet ${ }^{\star}$ for Transportation from HFIR to Building 3047} \\
\hline No. & Item & InitialiDate \\
\hline 36. & $\begin{array}{l}\text { Exit the HFIR loading area and proceed to the } 7900 \text {-area gate: } \\
\text { stop. } \\
\text { Clear vehicle and personnel for exit, then proceed via the HFIR } \\
\text { access road to the intersection with Melton Valley Drive: stop. } \\
\text { Tum left onto Melton Valley Drive and proceed to the bridge: } \\
\text { stop. } \\
\text { Proceed across the bridge with utmost caution: stop. } \\
\text { Tum right onto Lagoon Road and proceed to West Portal: stop. } \\
\text { Clear personnel and vehicles through West Portal, then proceed } \\
\text { east along Central Avenue to Fifth Street; stop. } \\
\text { Tum left onto Fifth Street and enter the Building } 3047 \text { loading } \\
\text { area on the south side: the CTD supervisor-in-charge will direct } \\
\text { positioning of the vehicle for off-loading. }\end{array}$ & \\
\hline 37. & $\begin{array}{l}\text { Initial date on quality, form, and other descriptive information } \\
\text { are entered on the forms by the RRD transportation coordinator. } \\
\text { then the forms are completed by appropriate personnel as the } \\
\text { operation proceeds. }\end{array}$ & \\
\hline 38. & Shipment has been received at Building 3047 . & \\
\hline
\end{tabular}

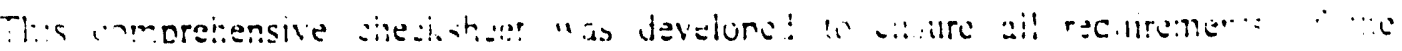
iransporation plan are satusticd. 

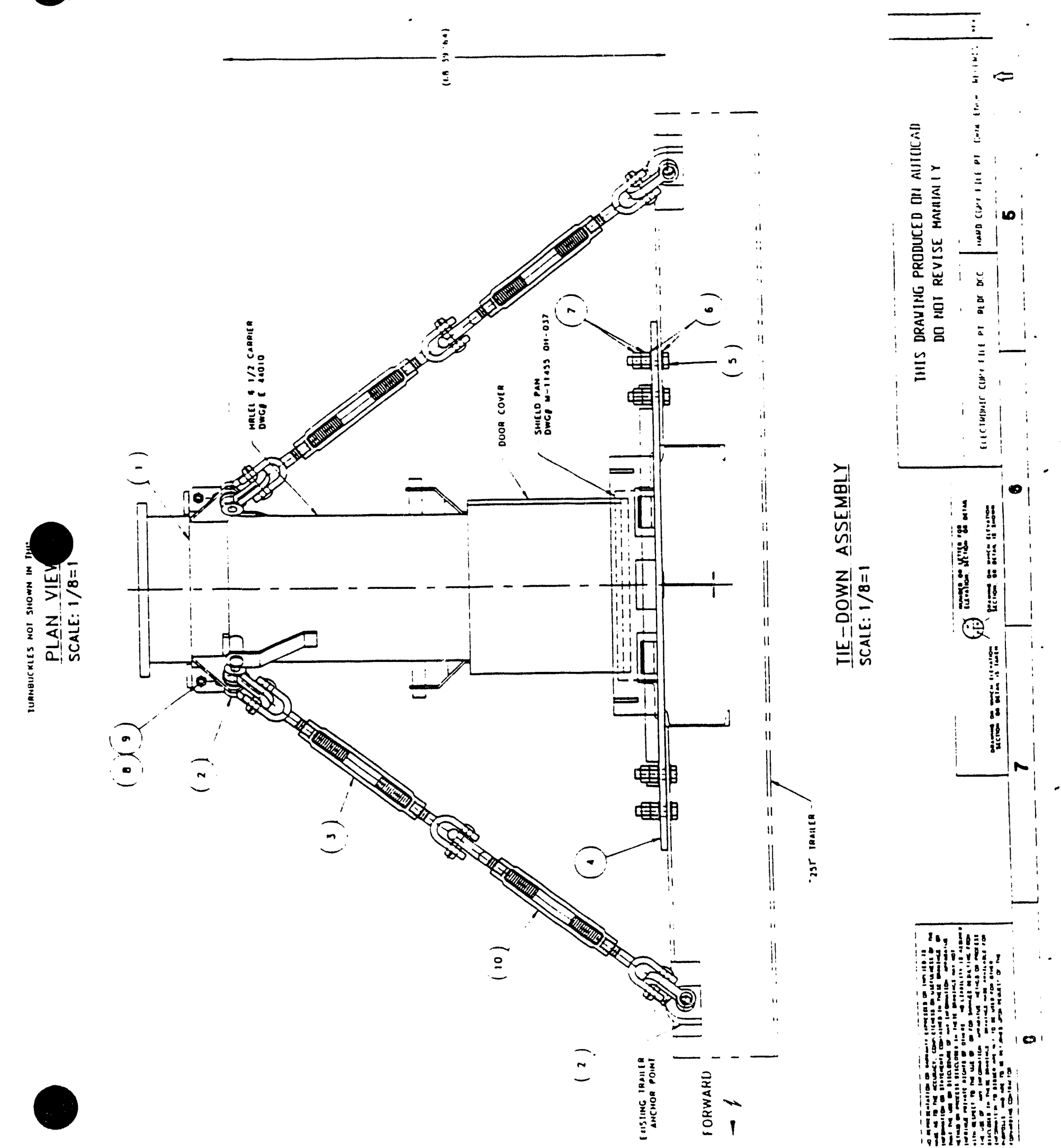

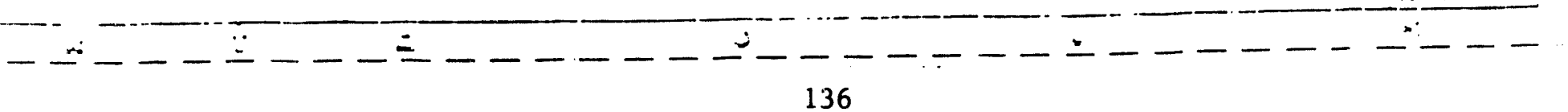




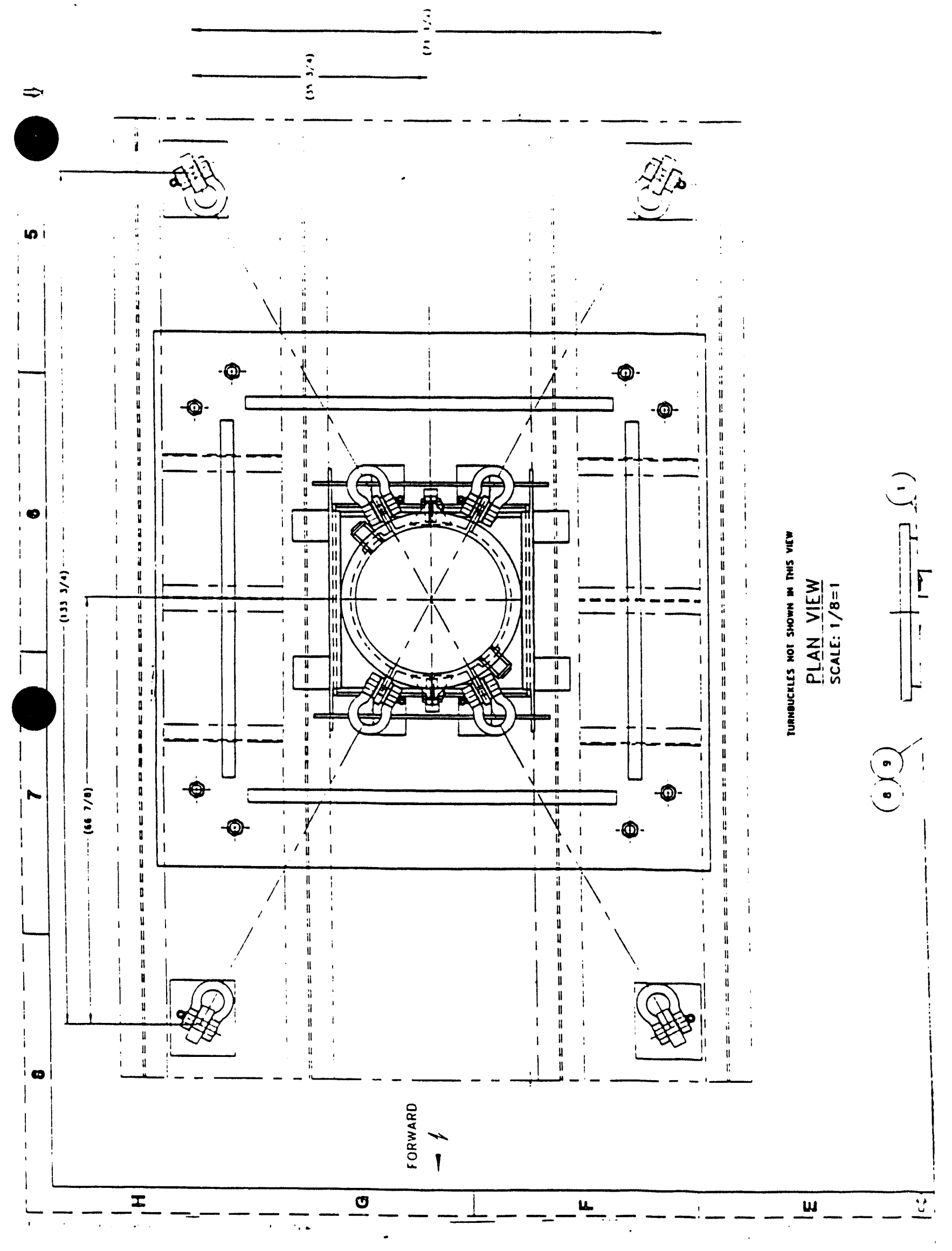




\section{CONVOY ASSIGNMENTS (Dry Run and Sunday Transfer)}

\section{SECURITY VEHICLE}

\section{LEAD VEHICLE}

Dave McGinty - Driver Roger Davis - Lead HP Call Sign: "UNIT ONE"

TRANSFER VEHICLE/TRAILER John Davis - Driver David Craft - HP Call Sign: "UNIT TWO"

TRAIL VEHICLE

John Dixon - Driver

Ken Curtis - HP

Call Sign: "UNIT THREE" 
Page 1 of

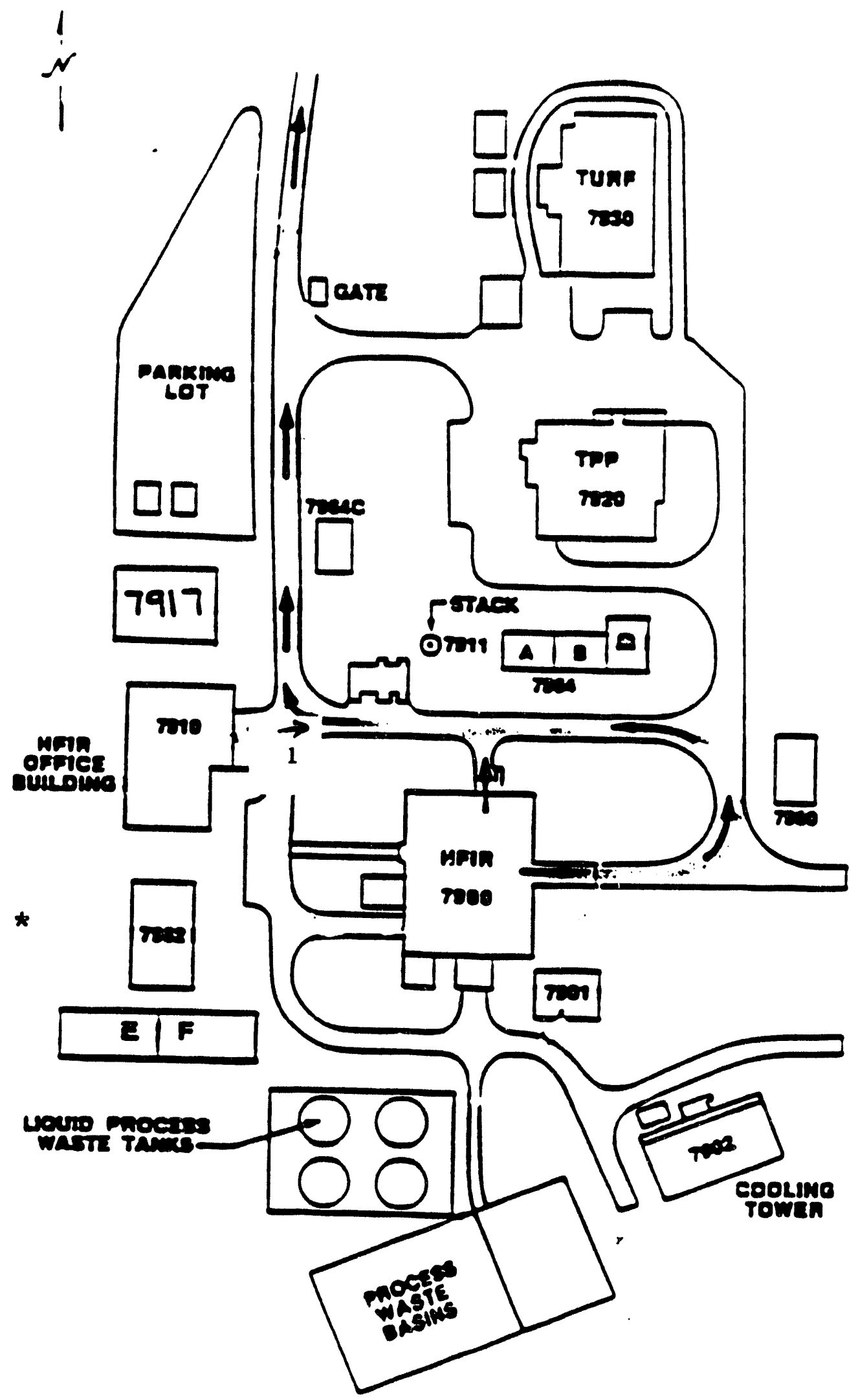




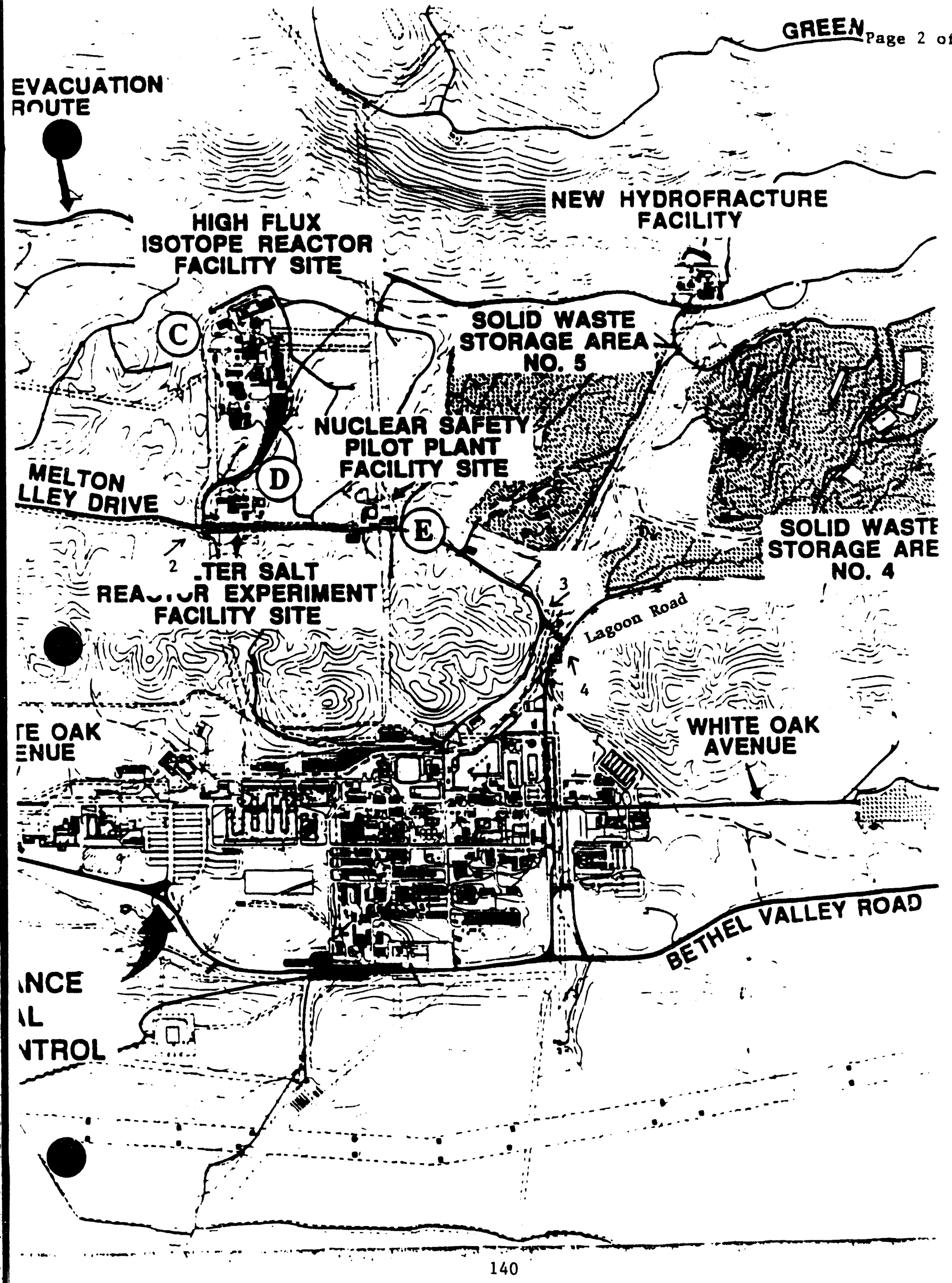




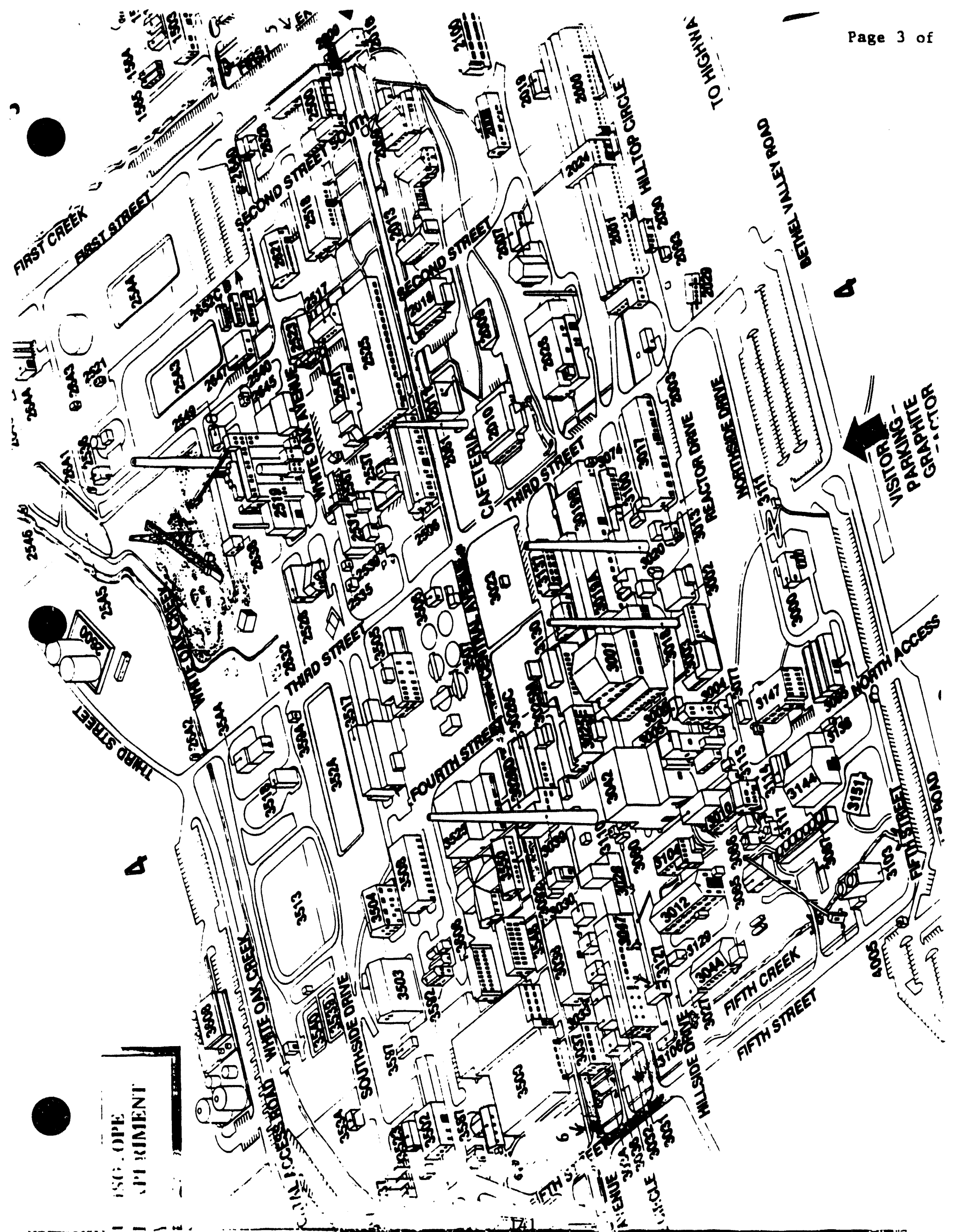




\section{RADIO COMMUNICATIONS PLAN FOR CASK TRANSFER (CORRECTED COPY)}

Radio Net RIN-294 will be used for this operation. Individual stations will be identified, as follows:

CALL SIGN
"UNIT ONE"
"UNIT TWO"
"UNIT THREE"
"BASE"

IDENTIFICATION

Convoy Commander (Dave McGinty) in the Lead Vehicle

Transfer Trailer (Cask Transporter)

Trail Vehicle

ORNL Emergency Operations center

The convoy commander will transmit radio messages to the EOC in the following format: "UNIT ONE to BASE, convoy is moving, the package has cleared seventy-nine hundred truck bay."

To insure that the message was correctly understood, the Eoc radio operator will repeat the message content, as follows: "BASE to UNIT ONE, convoy is moving, the package has cleared seventy-nine hundred truck bay."

If the feedback was correct, the convoy commander will say: "UNIT ONE, roger." If the feedback was incorrect, the convoy commander must transmit the whole message again.

The use of codewords, acronyms and abbreviations will be minimized in radio transmissions. Plain English will be maximized. For this operation, the cask containing the iridium-192 targets will be referred to as "the package."

The convoy commander will notify the EOC when "the package" reaches each of the following points on the route:

+ Exiting 7900 truck bay,

+ Clearing Post 19-B (Security Gate to 7900 area),

+ Turning left off of HFIR Access Road on to Melton Valley Road,

+ Arriving at east end of 7500 Bridge (White Oak creek),

+ Clearing the west end of 7500 Bridge,

+ Turning right on to Lagoon Road,

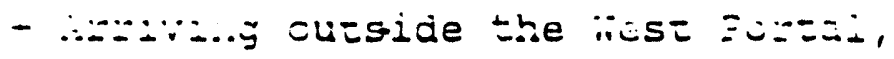

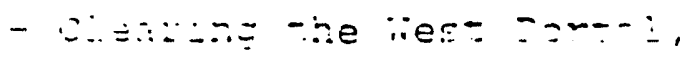




\section{(CORRECTED COPY)}

+ Turning left from Central Avenue on to Fifth Street,

+ Entering Isotope Circle on the south side of Building 3047 ,

+ Transfer trailer placed in position for off-loading of cask,

+ Rigging secured for off-loading of cask,

+ off-loading complete outside 3047 ,

+ Cask placed inside Building 3047.

NOTE: From this point on until the cask is secured inside Cell 3 , Brad Patton will provide telephonic reports to the EOC (Phone 6-8718 or 6-8719) from inside Building 3047. Patton plans to maintain an open line with the EOC, but if for some reason the call is disconnected, it will be his responsibility to reestablish the phone link.

The Fire Department and Security Patrol will operate on their own net, $\mathrm{KIN}-295$. Messages to and from them will be relayed through "BASE."

\#\#\#\# 


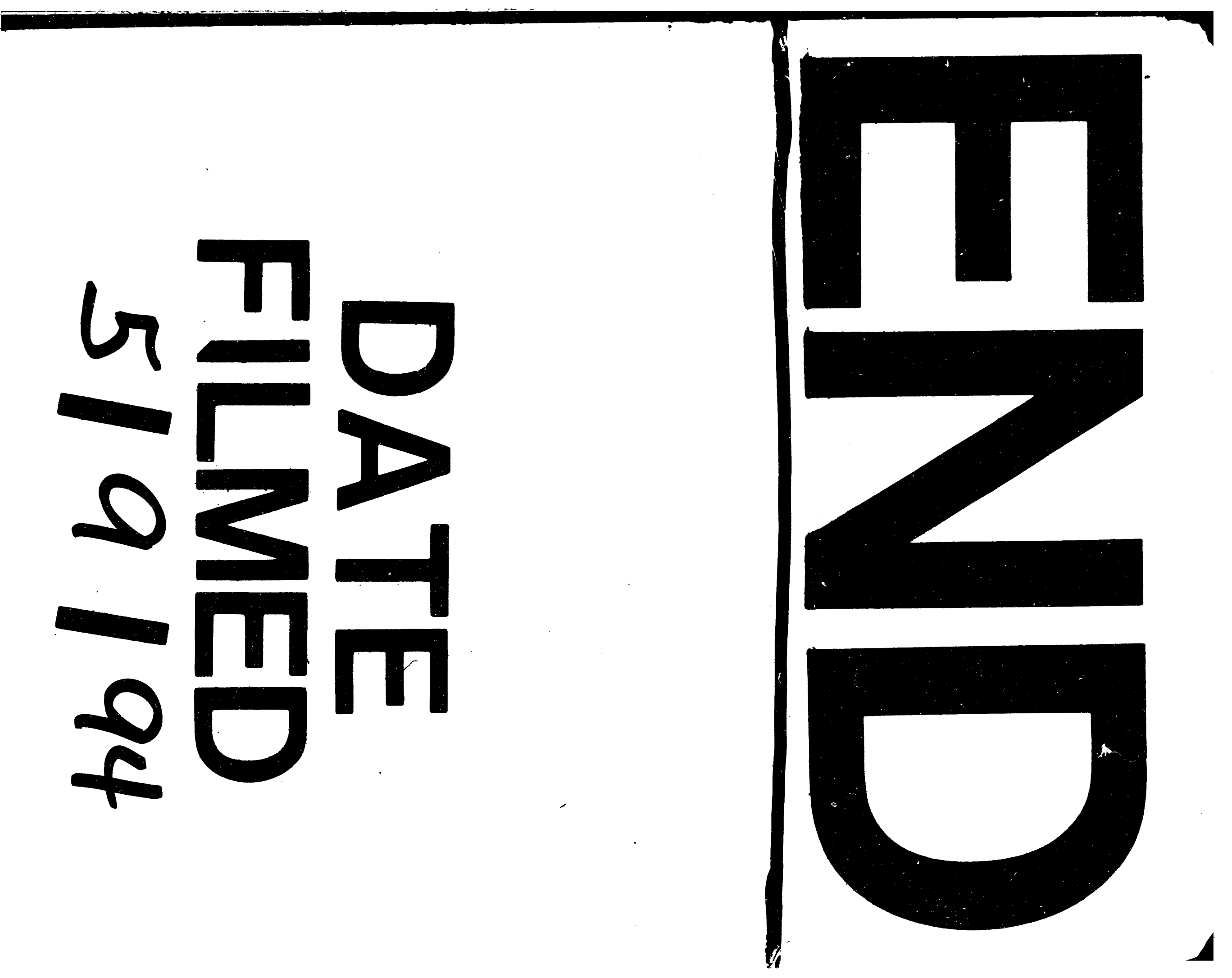


